\title{
Cameroon: Fourth Review Under the Three-Year Arrangement Under the Poverty Reduction and Growth Facility, Request for Waiver of Performance Criterion, and Financing Assurances Review-Staff Report; Staff Statement; Press Release on the Executive Board Discussion; and Statement by the Executive Director for Cameroon
}

In the context of the fourth review under the three-year arrangement under the Poverty Reduction and Growth Facility for Cameroon, and its request for waiver of performance criterion, and financing assurances review, the following documents have been released and are included in this package:

- $\quad$ the staff report for the Fourth Review Under the Three-Year Arrangement Under the Poverty Reduction and Growth Facility, Request for Waiver of Performance Criterion, and Financing Assurances Review, prepared by a staff team of the IMF, following discussions that ended on September 21, 2007, with the officials of Cameroon on economic developments and policies. Based on information available at the time of these discussions, the staff report was completed on November 30, 2007. The views expressed in the staff report are those of the staff team and do not necessarily reflect the views of the Executive Board of the IMF.

- a staff statement of December 19, 2007 updating information on recent developments.

- $\quad$ a Press Release summarizing the views of the Executive Board as expressed during its December 19, 2007 discussion of the staff report that completed the reviews.

- a statement by the Executive Director for Cameroon.

The document(s) listed below have been or will be separately released.

Joint Staff Advisory Note on the Poverty Reduction Strategy Paper Progress Report Poverty Reduction Strategy Paper-Progress Report Letter of Intent sent to the IMF by the authorities of Cameroon*

Memorandum of Economic and Financial Policies by the authorities of Cameroon*

* May also be included in Staff Report

The policy of publication of staff reports and other documents allows for the deletion of marketsensitive information.

To assist the IMF in evaluating the publication policy, reader comments are invited and may be sent by e-mail to publicationpolicy@imf.org.

Copies of this report are available to the public from International Monetary Fund $\bullet$ Publication Services

$70019^{\text {th }}$ Street, N.W. $\bullet$ Washington, D.C. 20431

Telephone: (202) 623-7430 • Telefax: (202) 623-7201

E-mail: publications@imf.org Internet: http://www.imf.org

Price: $\$ 18.00$ a copy

\section{International Monetary Fund} Washington, D.C. 



\title{
INTERNATIONAL MONETARY FUND \\ CAMEROON
}

\section{Fourth Review Under the Three-Year Arrangement Under the Poverty Reduction and Growth Facility, Request for Waiver of Performance Criterion, and Financing Assurances Review ${ }^{1}$}

\author{
Prepared by the African Department \\ (In collaboration with other departments) \\ Approved by David Nellor and Adnan Mazarei
}

November 30, 2007

\begin{abstract}
Recent developments. Nonoil economic activity has weakened reflecting under-execution of the capital budget, declining economic productivity related to the slow pace of structural reform implementation, and mounting external competition. High oil prices and production, however, improved the external current account. Inflation continued its downward trend.
\end{abstract}

Program performance. Despite mixed program performance, this report recommends completion of the fourth review under the PRGF arrangement owing to implementation of corrective actions. Most quantitative targets for end-June 2007 were met. Structural reform implementation was, however, uneven, with progress in strengthening budget management, but delays in reforming rural finance, the civil service, and public enterprises. The preparatory work to establish a financial subsidiary for the postal agency (performance criterion) was not completed by end-June, but corrective measures have been taken. In addition, the authorities have completed a preliminary diagnostic study of the civil service compensation system.

Main priorities. In light of continued weak nonoil economic activity, the authorities have stressed a renewed resolve to revive pro-poor growth. In this regard, the programmed level of public spending is preserved in 2008 despite the downward revision of nonoil revenues, implying larger-than-initially-envisaged fiscal stimulus. Investment will be reoriented toward agriculture development and infrastructure projects. The program includes measures to improve expenditure tracking and public investment execution, and strengthen tax administration. The authorities will take steps to improve the business environment; in this regard, they plan to speed the reform of public enterprises in telecommunications, water, and air transport sectors.

\footnotetext{
${ }^{1}$ The mission team comprised Mr. Ghura (head), Mr. Kpodar, and Mr. Singh (all AFR), Ms. Eble (FAD), Mr. Kireyev (PDR), and Ms. Kabedi-Mbuyi, Resident Representative. Mr. Nyambal, Senior Advisor to the Executive Director for Cameroon, as well as staff from the World Bank and the African Development Bank, participated in the discussions.
} 


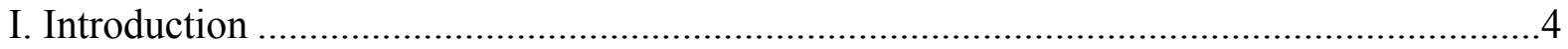

II. Recent Economic Developments and Program Implementation.....................................4

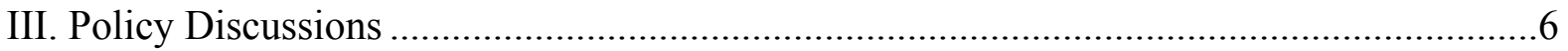

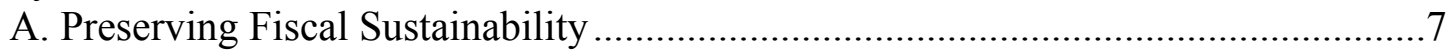

B. Improving the Business Environment ......................................................... 10

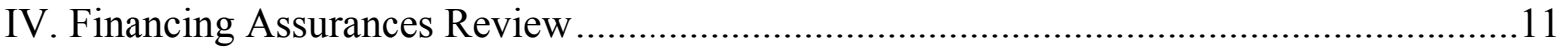

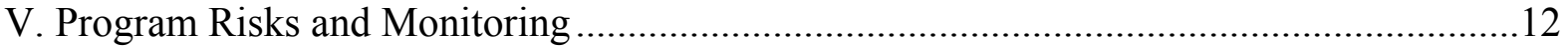

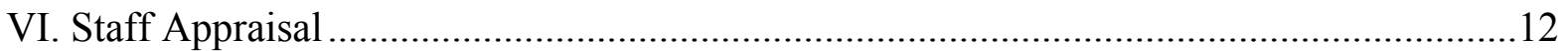

Tables

1. Selected Economic and Financial Indicators, 2004-09 …............................................ 17

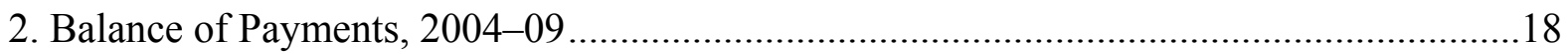

3. Monetary Survey, December 2004-December 2008 .......................................................19

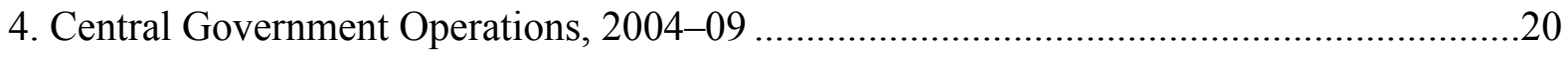

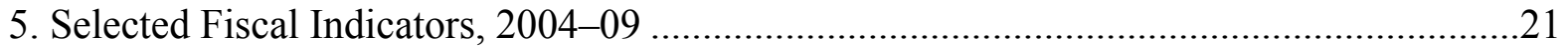

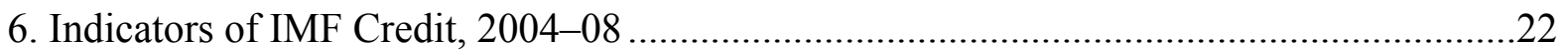

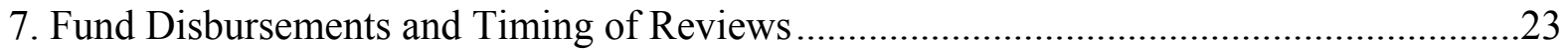

Figures

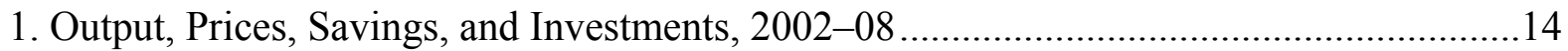

2. External Sector Developments and Prospects, 2002-08...............................................15

3. Fiscal Developments and Prospects, 2002-08 ............................................................ 16

Boxes

1. 2007 National FSAP- Main Findings and Recommendations ........................................11

Appendixes

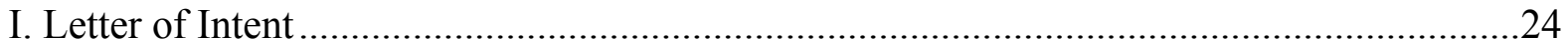

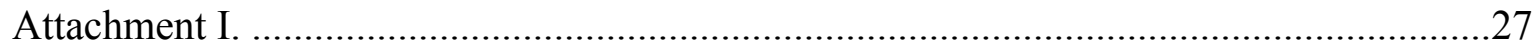

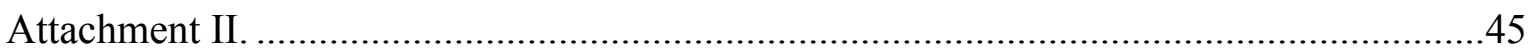




\section{Abbreviations and Acronyms}

BEAC

CAMAIR

CAMPOST

CAMTEL

CET

CEMAC

COBAC

EITI

FSAP

HIPC

IFC

JSAN

OECD-DAC

PRGF

PRS

REER

SNEC

SONARA

SME

WEO
Bank of Central African States

Cameroon airlines

Cameroon postal services

Cameroon telephone company

Common external tariff

Central African Economic and Monetary Community

Central African Banking Commission

Extractive Industry Transparency Initiative

Financial Sector Assessment Program

Heavily Indebted Poor Countries

International Finance Corporation

Joint Staff Advisory Note

Organization for Economic Cooperation and Development Development Assistance Committee

Poverty Reduction and Growth Facility

Poverty Reduction Strategy

Real effective exchange rate

National water supply company of Cameroon

National oil refinery

Small and medium-sized enterprise

World Economic Outlook 


\section{INTRODUCTION}

1. The fourth review concludes the second year under the PRGF arrangement and establishes the policy objectives for the program's final year. ${ }^{2}$ Discussions covered:

- recent developments, and assessment of program implementation in the first half of 2007; and

- policies to preserve fiscal sustainability and revive economic growth.

2. Following parliamentary elections, President Biya has renewed focus on boosting growth and poverty reduction. The President's party gained a majority of seats in the July 2007 parliamentary elections and in September the cabinet was reshuffled. Debt relief in 2006 has generated expectations of civil service salary adjustments and better public service delivery. The new cabinet promises to give a new impetus to reforms, while at the same time expectations of higher public spending could test its resolve to resist expenditure pressures.

\section{RECENT ECONOMIC DEVELOPMENTS AND PROGRAM IMPLEMENTATION}

3. Economic growth remains weak despite high oil prices (Tables 1 and 2). Nonoil sector activity has been weak reflecting increased competition from low-cost producers, under-execution of public investment, and declining productivity related to delays in public enterprise restructuring. According to a mid-year assessment, nonoil activity is picking up slightly owing to recovery in construction and agriculture. High oil prices and production have supported oil activities and, combined with a significant increase in timber exports, improved the external current account.
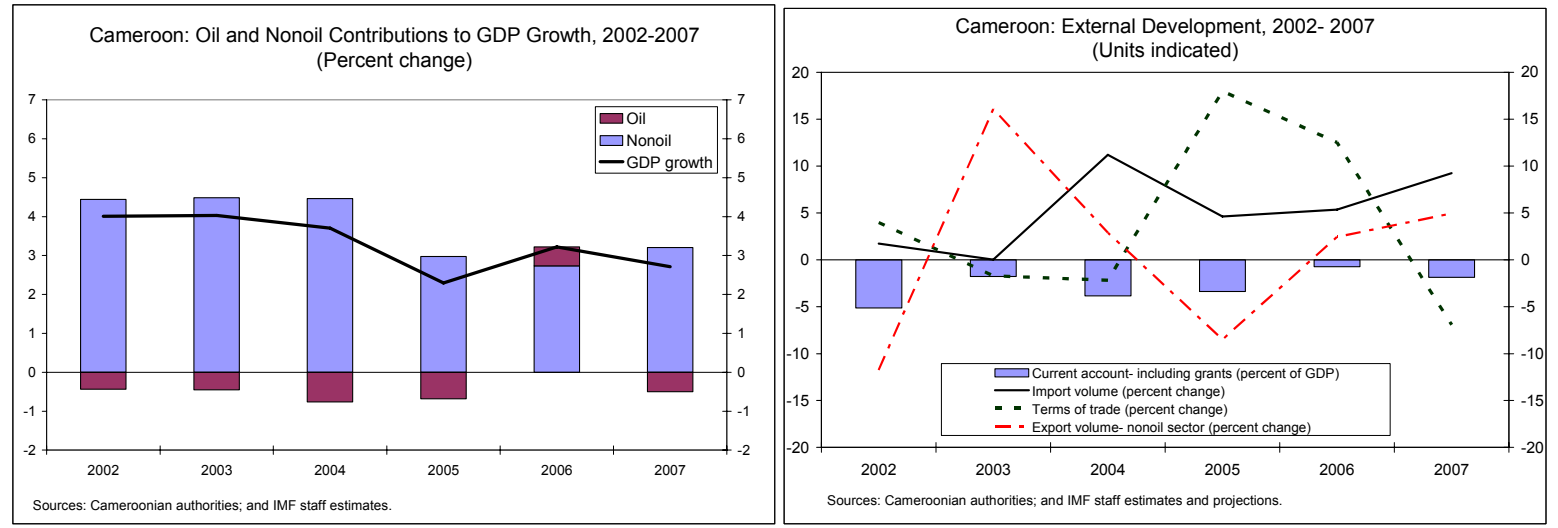

\footnotetext{
${ }^{2}$ The authorities have prepared an Annual Progress Report on their PRS implementation in 2006. The APR and the JSAN have been issued to the Executive Board as separate documents.
} 


\section{Monetary developments in the first half of 2007 continued to be driven by high} oil prices, while inflation declined (Table 3). The surge in net foreign assets abated and a continued reduction of government liabilities to the banking system helped contain broad money growth. Private sector credit growth remained subdued as the government repaid arrears to private operators, allowing them to scale back outstanding credit to banks and self finance their operations. Inflation declined further, as fuel price hikes moderated and taxation on some staple goods was reduced. The REER continued to appreciate, as the euro- to which the CFAF is pegged - strengthened. ${ }^{3}$

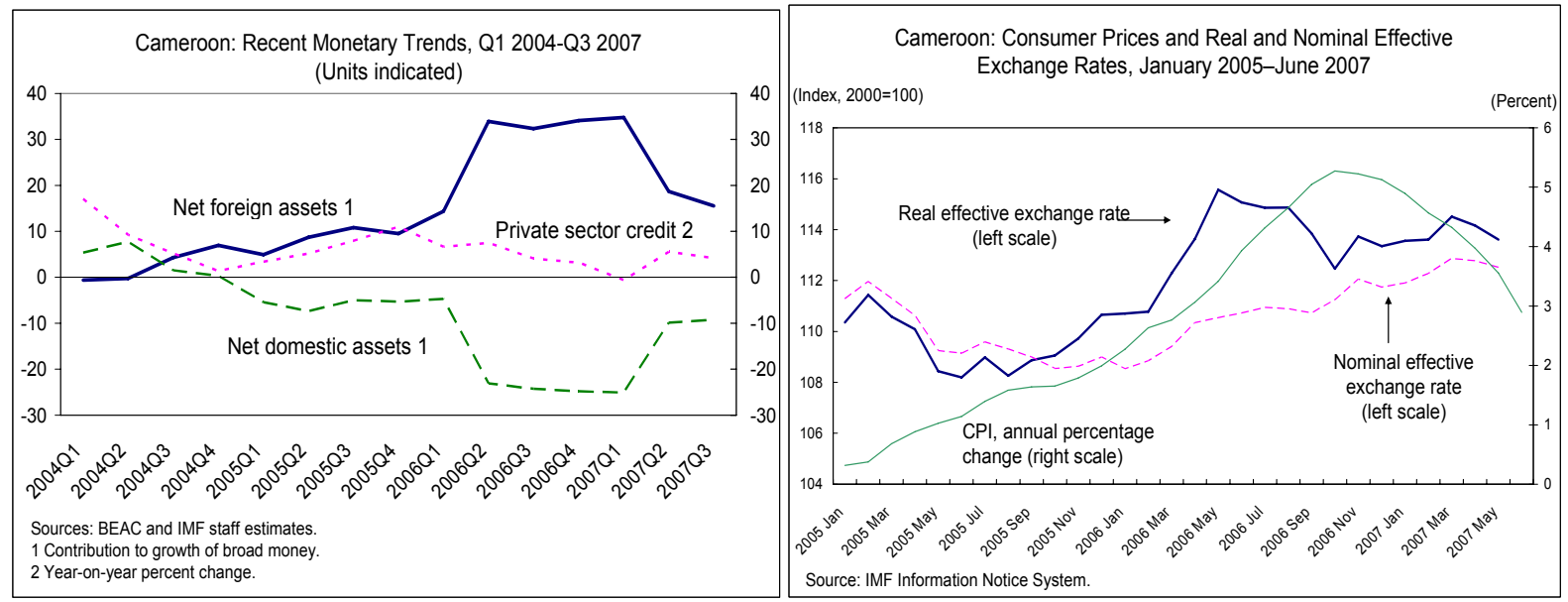

5. Fiscal performance in the first half of 2007 was broadly satisfactory, though concerns about investment execution remain. The overall fiscal surplus was higher than projected, reflecting lower-thanprojected spending. Nonoil revenues underperformed by a slight margin because both taxes on international trade and nontax revenues fell short of expectations. Nonetheless, the tax effort was maintained despite lower economic growth. As regards investment execution, while domestically-financed investment was close to the

\begin{tabular}{|c|c|c|c|c|c|c|}
\hline \multicolumn{7}{|c|}{ Cameroon. Key Fiscal Indicators, 2005-07 } \\
\hline & \multirow[t]{3}{*}{2005} & \multirow[t]{3}{*}{2006} & \multicolumn{4}{|c|}{$2007^{1}$} \\
\hline & & & \multicolumn{2}{|c|}{ Jan-June } & \multicolumn{2}{|c|}{ Year } \\
\hline & & & Prog. & Actual & Prog. & Proj. \\
\hline & \multicolumn{6}{|c|}{ (Percent of GDP) } \\
\hline Total revenue and grants & 18.2 & 47.6 & 9.6 & 9.5 & 19.1 & 20.2 \\
\hline Oil revenue & 5.0 & 6.8 & 2.6 & 2.4 & 5.2 & 5.9 \\
\hline Nonoil revenue & 12.6 & 12.4 & 6.4 & 6.4 & 12.6 & 12.7 \\
\hline Grants & 0.5 & 28.4 & 0.6 & 0.8 & 1.3 & 1.5 \\
\hline Total expenditure & 14.6 & 14.5 & 8.2 & 6.8 & 16.8 & 16.3 \\
\hline Current & 12.1 & 11.7 & 5.8 & 5.6 & 11.9 & 12.1 \\
\hline $\begin{array}{l}\text { Capital } \\
\text { of which: }\end{array}$ & 2.4 & 2.9 & 2.3 & 1.2 & 4.9 & 4.2 \\
\hline Foreign-financed & 0.5 & 0.7 & 0.5 & 0.3 & 1.1 & 0.9 \\
\hline Own resources & 1.2 & 1.5 & 0.7 & 0.7 & 1.8 & 1.9 \\
\hline Debt-relief financed & 0.6 & 0.4 & 0.8 & 0.2 & 1.5 & 1.1 \\
\hline Unclassified & 0.2 & -0.1 & 0.0 & 0.0 & 0.0 & 0.0 \\
\hline Net change in arrears & -0.8 & -1.8 & -0.2 & -0.4 & -0.6 & -0.7 \\
\hline Overall balance (excluding grants) & 2.2 & 2.9 & 0.6 & 1.6 & 0.4 & 1.6 \\
\hline Memorandum items & \multicolumn{6}{|c|}{ (Percent of nonoil GDP) } \\
\hline Nonoil revenue as share of nonoil GDP & 13.8 & 13.8 & 6.9 & 7.0 & 13.6 & 13.9 \\
\hline Nonoil primary balance (program definition) ${ }^{2}$ & 1.0 & 0.4 & 0.1 & 0.5 & -0.4 & -0.5 \\
\hline
\end{tabular}
budget target, foreign- and debt relief-financed investments were lower.

\footnotetext{
${ }^{3}$ Staff estimates that the REER is close to its equilibrium, though nonprice factors, such as a weak investment climate, continue to hamper external competitiveness (Country Report No. 07/285).
} 
6. Performance under the PRGF-supported program over January-June 2007 was mixed but corrective actions have been taken (MEFP, Tables 1-2):

- All quantitative targets for end-June 2007 were met, with the exception of the benchmark on nonoil revenue. The authorities kept the momentum of the tax effort through reinforced revenue administration measures. The nonoil revenue target for 2007 was lowered in light of weaker nonoil economic activity, though the revenue effort under the program has been maintained. The authorities will lower spending while safeguarding priority outlays, implying a slightly larger-than-programmed nonoil primary fiscal deficit in 2007.

- Structural measures related to budget management and transparency were implemented. The online connection between the IT systems of the general directorates of the Budget and the Treasury was consolidated (performance criterion).

- Delays were registered in measures related to rural finance and civil service.

Preparatory work to establish a financial subsidiary for CAMPOST was not completed by end-June (performance criterion), this process turning out to be more complex than envisaged. However, with the 2004-06 financial accounts produced and a business plan for the financial activities of CAMPOST prepared, the objective of this measure has been met. Going forward, ensuring appropriate supervision will be critical to protecting small depositors (MEFP, $₫$ 5 and 35).

$>$ The benchmark to conduct a diagnostic study of the civil service was met with delay. The end-June benchmark on the payroll management of selected ministries was, however, partially met: personnel records were harmonized, but the new management system could not be installed as envisaged, given a change in the choice of information technology. Reform implementation will continue with the harmonization of payroll records by end-2007 and installation of a management system by mid-2008 (MEFP, $\uparrow 24$ ).

7. Progress in reforming public enterprises was slow. The authorities are pursuing public enterprise reform with the assistance of the World Bank. The bids for the privatization of CAMTEL was issued at end-March (performance criterion); a provisional bidder for the company is now expected to be selected by end-2007. A provisional bidder for SNEC was selected in September 2007 and the management contract is expected to be signed by end-2007. On CAMAIR, the government reiterated its commitment to reduce subsidies and improve services. A new financial advisor for CAMAIR's privatization is expected to be selected by end-2007 (MEFP, $₫ 38$ ).

\section{Policy Discussions}

8. The authorities stressed their resolve to revive pro-poor growth, while preserving fiscal sustainability. Options to accelerate growth were discussed. In this regard, 
the authorities will (i) maintain the programmed level of public spending in 2008, despite the downward revision of nonoil revenues due to lower growth, implying a larger-than-initiallyprojected fiscal stimulus; (ii) accelerate priority spending and refocus capital spending on projects in infrastructure and agriculture; (iii) improve investment execution; and (iv) accelerate structural reforms, in particular steps to improve the business climate. ${ }^{4}$ Coupled with cocoa and coffee plantations reaching maturity, these efforts are expected to result in a modest rebound in nonoil activity starting in 2008 .

\section{A. Preserving Fiscal Sustainability}

\section{The medium-term fiscal strategy aims at expanding priority spending, while} preserving macroeconomic sustainability. It assumes (i) conservative oil prices; (ii) a gradual increase in nonoil revenues; (iii) expanded poverty-related spending and restrained nonpriority spending; and (iv) continued repayment of domestic debt. ${ }^{56}$

\section{The proposed 2008 budget is in line with the above objectives and the original}

program. Key features include:

- an expected increase in nonoil revenue of 0.3 percentage point of nonoil GDP relative to 2007 , reflecting ongoing improvements in tax administration;

- broadly unchanged current expenditure (relative to GDP) with lower subsidies and transfers offsetting higher spending on wages and salaries; and

- a rise in capital spending of about 1 percentage point of GDP relative to 2007 because of improved execution of debt relief- and foreign-financed projects.

\footnotetext{
${ }^{4}$ The nonoil primary fiscal deficit will, however, remain within the sustainable target range (Country Report No. 07/285).

${ }^{5}$ Oil price projections are set below WEO prices by a constant prudence factor currently amounting to US\$7 dollars per barrel, in addition to a US\$3 dollar per barrel quality discount.

${ }^{6}$ The stock of outstanding domestic debt was 9 percent of GDP at end-2006.
} 
Cameroon: Selected Macroeconomic Indicators, 2006-09

(Units indicated)

\begin{tabular}{|c|c|c|c|c|c|c|c|}
\hline & \multirow[b]{2}{*}{2006} & \multicolumn{3}{|c|}{ Baseline ${ }^{1}$} & \multicolumn{3}{|c|}{ Updated Scenario } \\
\hline & & 2007 & 2008 & 2009 & 2007 & 2008 & 2009 \\
\hline \multicolumn{8}{|l|}{ Economic growth and prices } \\
\hline Real GDP ${ }^{2}$ & 3.2 & 4.2 & 4.9 & 4.8 & 2.7 & 4.4 & 4.6 \\
\hline Of which: nonoil & 2.9 & 4.4 & 5.2 & 5.3 & 3.4 & 4.5 & 4.9 \\
\hline Consumer prices (period average) & 5.1 & 1.8 & 1.8 & 2.0 & 1.5 & 3.3 & 2.0 \\
\hline Program oil price (U.S. dollars per barrel) & 61.6 & 50.0 & 54.8 & 51.5 & 62.8 & 65.0 & 59.3 \\
\hline Gross domestic investment & 16.8 & 20.1 & 21.5 & 22.8 & 18.4 & 19.4 & 20.0 \\
\hline \multicolumn{8}{|l|}{ Fiscal aggregates ${ }^{3}$} \\
\hline Total revenue (excl. grants) & 19.3 & 17.7 & 17.9 & 17.6 & 18.6 & 18.4 & 18.5 \\
\hline Of which: nonoil ${ }^{4}$ & 13.8 & 13.6 & 13.7 & 13.9 & 13.9 & 14.2 & 14.4 \\
\hline Total expenditure & 14.5 & 16.8 & 16.8 & 16.9 & 16.3 & 17.3 & 17.9 \\
\hline Of which: noninterest current & 10.7 & 11.4 & 11.3 & 11.3 & 11.6 & 11.7 & 11.8 \\
\hline capital & 2.9 & 4.9 & 5.1 & 5.1 & 4.2 & 5.2 & 5.7 \\
\hline Overall budget balance (excl. grants) & 4.7 & 1.0 & 1.0 & 0.7 & 2.4 & 1.1 & 0.5 \\
\hline Of which: nonoil primary fiscal balance ${ }^{4.5}$ & 0.4 & -0.4 & -0.6 & -1.0 & -0.5 & -0.7 & -1.0 \\
\hline Overall budget balance (incl. grants) & 33.1 & 2.3 & 2.1 & -1.0 & 3.9 & 1.9 & 1.5 \\
\hline Fiscal stimulus $^{4}$ & 0.6 & 2.7 & 0.0 & -0.2 & 1.8 & 1.0 & 0.3 \\
\hline \multicolumn{8}{|l|}{ Balance of payments } \\
\hline Current account (excl. grants $\left.{ }^{3}\right)$ & -0.7 & -4.0 & -4.8 & -5.8 & -2.6 & -3.1 & -3.6 \\
\hline Export volume ${ }^{2}$ & 8.1 & 4.2 & 3.6 & 3.8 & 2.8 & 4.0 & 4.0 \\
\hline Of which: nonoil & 8.7 & 5.0 & 5.4 & 5.9 & 5.1 & 5.4 & 5.9 \\
\hline Import volume $e^{2}$ & 6.8 & 5.4 & 5.5 & 5.9 & 9.6 & 3.7 & 3.3 \\
\hline Of which: nonoil & 2.4 & 7.2 & 8.7 & 6.0 & 8.5 & 3.9 & 4.9 \\
\hline \multicolumn{8}{|c|}{ Sources: Cameroonian authorities; and IMF staff estimates and projections. } \\
\hline \multicolumn{8}{|l|}{$\begin{array}{l}{ }^{1} \text { Based on Country Report } \\
{ }^{2} \text { Percentage change. } \\
{ }^{3} \text { Percent of GDP. } \\
{ }^{4} \text { Percent of nonoil GDP. } \\
{ }^{5} \text { Excluding foreign-finance }\end{array}$} \\
\hline
\end{tabular}

\section{The authorities agreed that nonoil revenue mobilization remained key to} ensuring fiscal sustainability. They recognize the importance of further mobilizing nonoil revenues to build fiscal space for priority spending, against the backdrop of an expected decline in oil revenues and trade liberalization. To complement ongoing administrative improvements, they will refrain from introducing new tax exemptions and explore options for rationalizing existing ones.

Furthermore, should revenue fall short

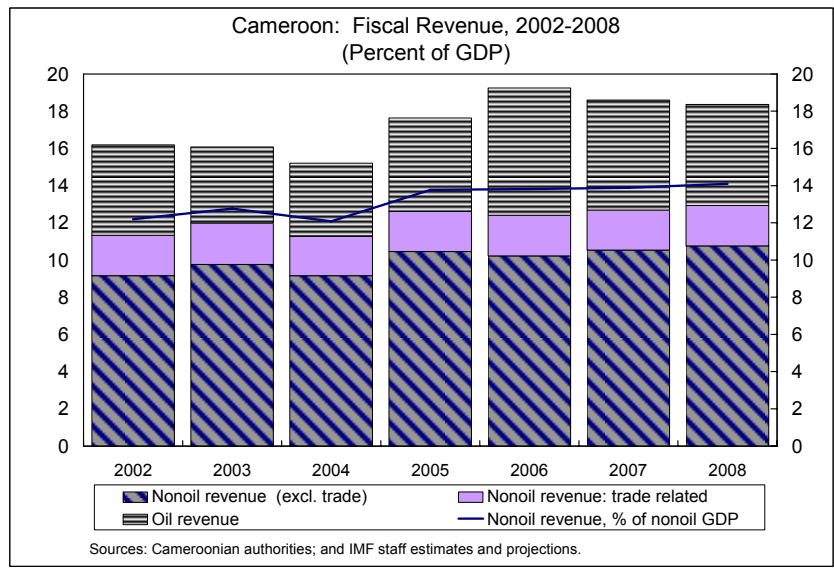
of projections, they agreed to take additional measures, including reversing the tax exemptions granted in 2006 and taxing fringe benefits (MEFP, $\mathbb{1 1 1 - 1 3 ) .}$ 


\section{The authorities recognize that low debt relief- and foreign-financed investment} execution impeded faster growth and poverty reduction. They noted that Cameroon was lagging regional comparators with regard to capital spending. They plan to address the impediments to higher investment execution, while safeguarding project quality, by

(i) budgeting adequate counterpart funds; (ii) executing the investment budget within a medium-term framework; (iii) starting the procurement process early in the budget cycle; and (iv) improving coordination with donors (MEFP, $\{20-22$ ).
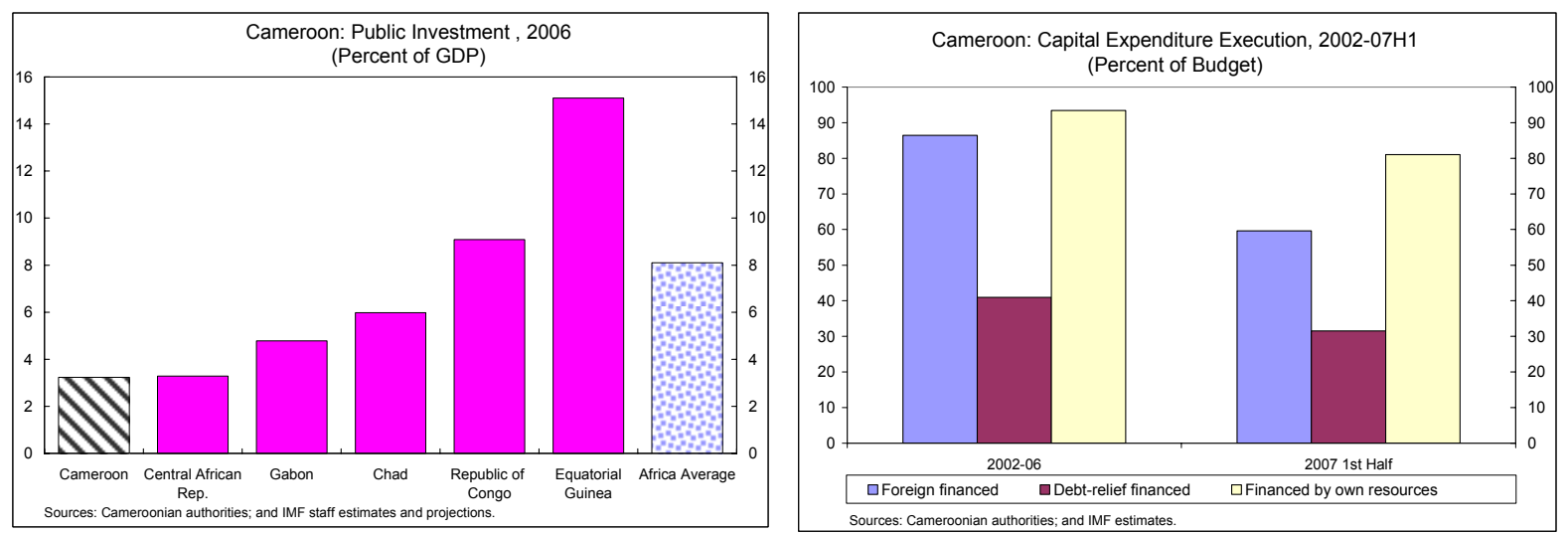

13. It will also be critical to ensure the quality of public spending. In this area, the authorities are focusing on improving human resource and public financial management, and containing fiscal risks:

- The wage bill is projected to rise by about 10 percent reflecting both (i) pay regularization of employees whose salary increase after promotion had been frozen; and (ii) new hiring in priority sectors. The authorities reiterated their commitment to adjust public salaries in the context of civil service reforms.

- To strengthen medium-term expenditure planning, budget execution and tracking, the authorities intend to prepare a public financial management action plan (MEFP, $\mathbb{1 1 9}$ ). They also plan to submit to Parliament a new organic budget law in 2007 aimed at modernizing the budget framework and have requested technical assistance from the Fund.

- With a view to lowering subsidies and creating fiscal space for priority spending, the authorities will adopt a simplified fuel price adjustment mechanism to reflect movements in world prices (MEFP, $\llbracket 25-26$ ).

- They are making progress in developing a public debt policy. The policy would set indicative sustainability thresholds, formalize the current prudent borrowing policy of relying on concessional loans and grants, and follow best practices in transparency and accountability. Furthermore, the authorities have adopted a legal framework to foster public-private partnerships and are committed to minimize the fiscal risks involved in such transactions. 


\section{B. Improving the Business Environment}

14. To revive growth, the authorities recognize that the business environment needs to improve. They will continue to take actions in areas identified in business surveys as core to attracting investment - developing the financial sector, opening trade, and improving transparency and governance. With the assistance of the World Bank, efforts are also being made to strengthen the business climate.

\section{Financial sector}

15. The financial sector needs deepening. The authorities will prepare a medium-term action plan to deepen financial intermediation, following the recommendations of the recent FSAP mission (Box 1) (MEFP, ๆ32). The authorities argued that dealing with the structural impediments to financial intermediation would take time and the government may have a role in the interim. Staff expressed caution, noting that past public intervention in the financial sector had not improved intermediation, while implying fiscal costs.

16. Alternatives to direct government borrowing from the BEAC will be developed. To foster greater capital market development, the authorities will allow secondary market transactions on zero-coupon government debt to take place on the bond market. They also plan to limit recourse to statutory advances from the BEAC starting in 2008 and instead issue government debt (MEFP, $\mid 34$ ), a reform for which they will need technical assistance.

\section{Trade}

17. Trade liberalization will contribute to lowering the cost of doing business. The authorities have reiterated that Cameroon would take the lead in the reform of the CEMAC region. In this regard, they will propose to other CEMAC countries that the rules of origin be harmonized and that CET exemptions be revised. They will also support the implementation of the CEMAC directive on the reduction of the maximum CET rate from 30 to 20 percent $^{7}$ (MEFP, $\uparrow 31$ ).

\footnotetext{
${ }^{7}$ This rate reduction could imply an annual revenue shortfall of about $1 / 2$ percent of GDP.
} 


\section{Box 1. Cameroon: 2007 National FSAP- Main Findings and Recommendations}

\section{Key findings}

- Prudential requirements at the regional level may not adequately reflect risks.

- The cap on lending rates hampers credit access for SMEs and less creditworthy borrowers.

- The national treasury and central bank need to reorient their liquidity management toward market-based techniques.

- Reliable information on borrowers is limited.

- Lack of training of judges and governance problems in the judicial system hamper loan recovery and execution (foreclosing) of guarantees.

\section{Key recommendations}

At the regional level:

$>$ raise key prudential ratios

$>$ strengthen COBAC's capacity

$>$ adjust administered interest rates to reflect market conditions

$>$ cease utilizing statutory advances

$>$ adopt a framework for credit bureaus

At the national level:

$>$ enhance the supervision of microfinance institutions

$>$ introduce treasury bills and develop the bond market

$>$ ease regulations governing branch and ATM networks

$>$ enhance information base on debtor risk

$>$ improve commercial and land registries

$>$ strengthen the judicial system

\section{Transparency and governance}

18. Continued efforts to improve governance would reduce regulatory and judicial uncertainty. The authorities will appoint members to the commission that will implement the law requiring high public officials to declare their assets. Furthermore, under the OECDDAC initiative, they will prepare an anticorruption strategy action plan. Publication of corruption-related court decisions and administrative sanctions will continue (MEFP, $\{36$ ).

\section{Financing Assurances RevieW}

\section{Given Cameroon's arrears to private external creditors, issues related to}

financing assurances were discussed. The staff reiterated the importance of resolving pending litigations with relevant creditors in line with Cameroon's commitments to the Paris 
Club of offering comparable treatment for nonparticipating creditors. ${ }^{8}$ Negotiations with private creditors are ongoing. Cameroon has offered terms that are comparable with the enhanced HIPC Initiative and a few have agreed to forgo accumulated interest and penalties but have insisted that Cameroon repay the principal in full.

\section{Program Risks And Monitoring}

20. The program is subject to risks, notably in the areas of revenue mobilization, expenditure control, and growth. Slower progress in mobilizing nonoil revenue could compromise the fiscal objectives, especially the goal to fund a sustained increase in priority spending. Furthermore, expectations of higher public expenditure after debt relief could test the authorities' resolve to resist spending pressures. If improvements in the business environment are also lackluster and execution of the investment budget is weak, these developments could jeopardize the program's growth and poverty reduction objectives.

21. Program implementation will continue to be monitored every six months on the basis of quantitative and structural performance criteria, benchmarks, and indicative targets (MEFP, Tables 3-4).

\section{Staff APPRAisal}

22. Staff welcomes the authorities' renewed focus on accelerating economic growth. Continued weak nonoil economic activity calls for determined action. In this regard, increased focus should be given to measures to improve the quality of public spending, enhance the execution of capital- and poverty-reducing outlays, strengthen the business environment, and improve governance. The authorities' commitment to further strengthen the financial sector is welcome. More resolute public enterprise reform would also help consolidate gains in economic efficiency and open opportunities for private investment.

\section{Staff commends the authorities for strengthening public financial management,} but urges them to accelerate public enterprise and civil service reforms. Fiscal performance and implementation of structural measures related to public finance management were good. Nonetheless, delays in improving investment execution, as well as in reforming rural finance and public enterprises, raised concerns about achieving the faster growth needed to substantially lower poverty.

24. Staff urges the authorities to stay on course on program implementation. Greater nonoil revenue mobilization will be critical to finance priority spending in light of the expected decline in oil revenue and trade liberalization, while preserving fiscal sustainability.

\footnotetext{
${ }^{8}$ Of the 22 commercial creditors that did not participate in the 2003 debt buy-back operation, 5 have resorted to litigation. The authorities have signed bilateral debt cancellation agreements with most official creditors and expect to conclude discussions with remaining creditors.
} 
Delays in implementing measures related to rural finance and civil service are regrettable, but staff welcome the remedial actions that have been taken.

25. Staff recommends that the Board:

- grant a waiver for the nonobservance of the performance criterion related to the completion of the preparatory work for the establishment of a financial subsidiary of CAMPOST, based on the corrective steps taken that have allowed the objective of this performance criterion to be met;

- complete the fourth review under the PRGF arrangement, in view of the broadly satisfactory program implementation, corrective actions taken, and commitments made for the program's third year; and

- complete the financing assurances review, given that Cameroon's current relations with its external creditors offer sufficient financing assurances for the Fund-supported program. 
Figure 1. Cameroon: Prices, Output, Savings, and Investments, 2002-08

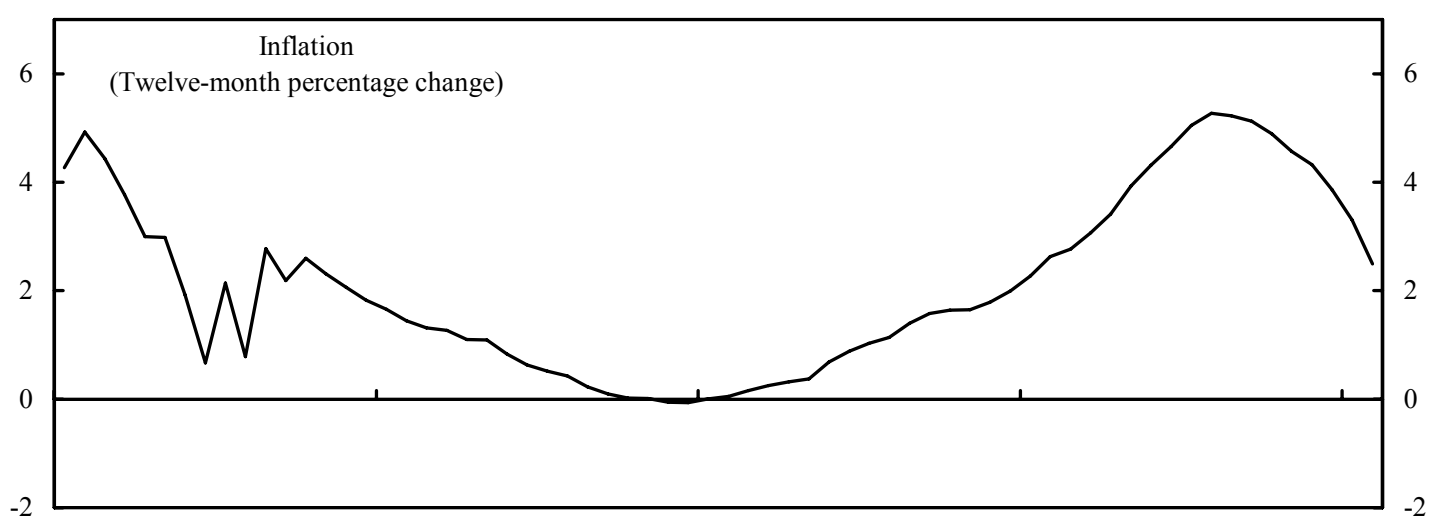

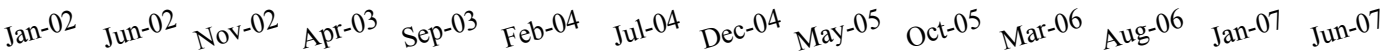
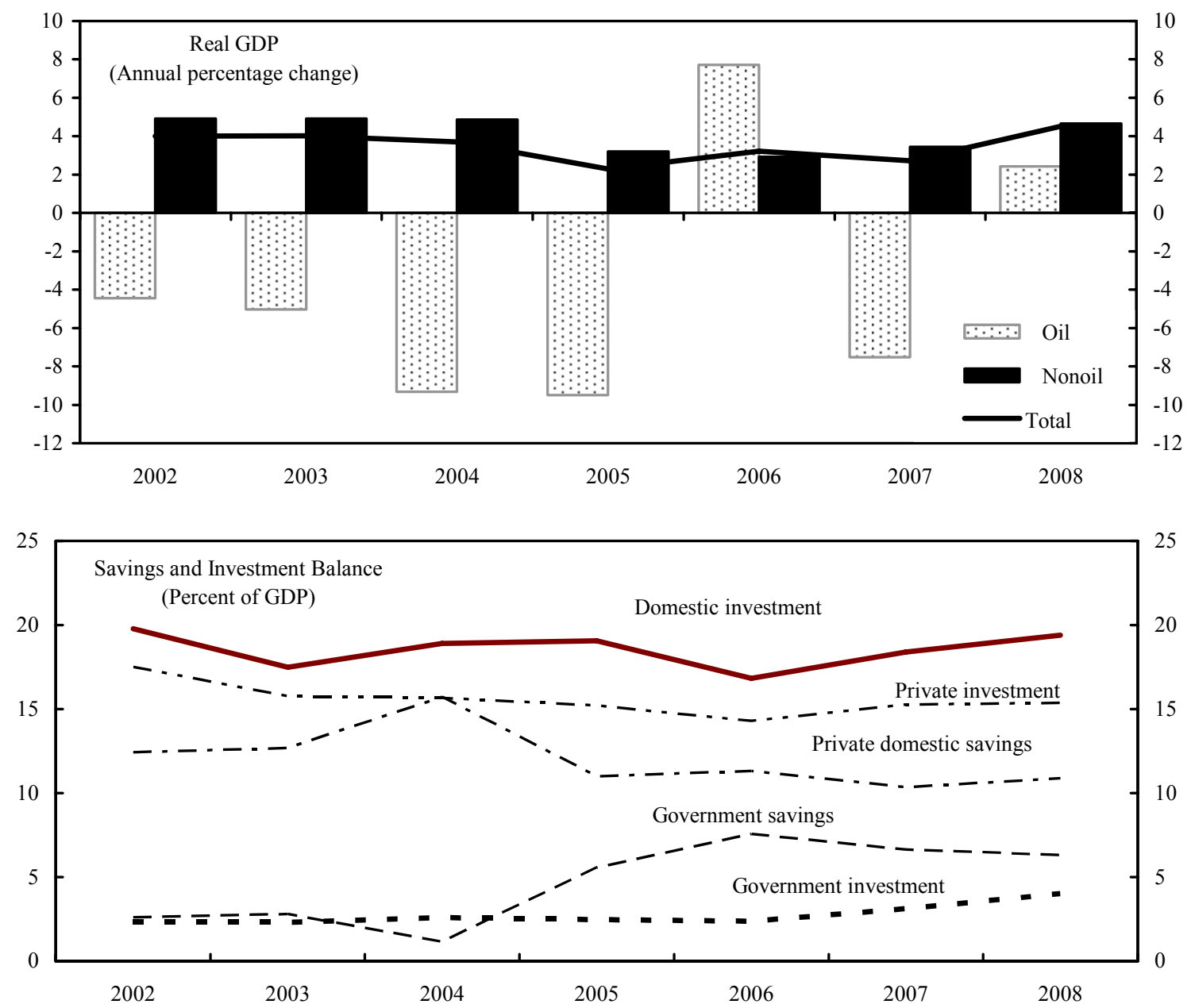

Sources: Cameroonian authorities; and IMF staff estimates and projections. 
Figure 2. Cameroon: External Sector Developments and Prospects, 2002-08
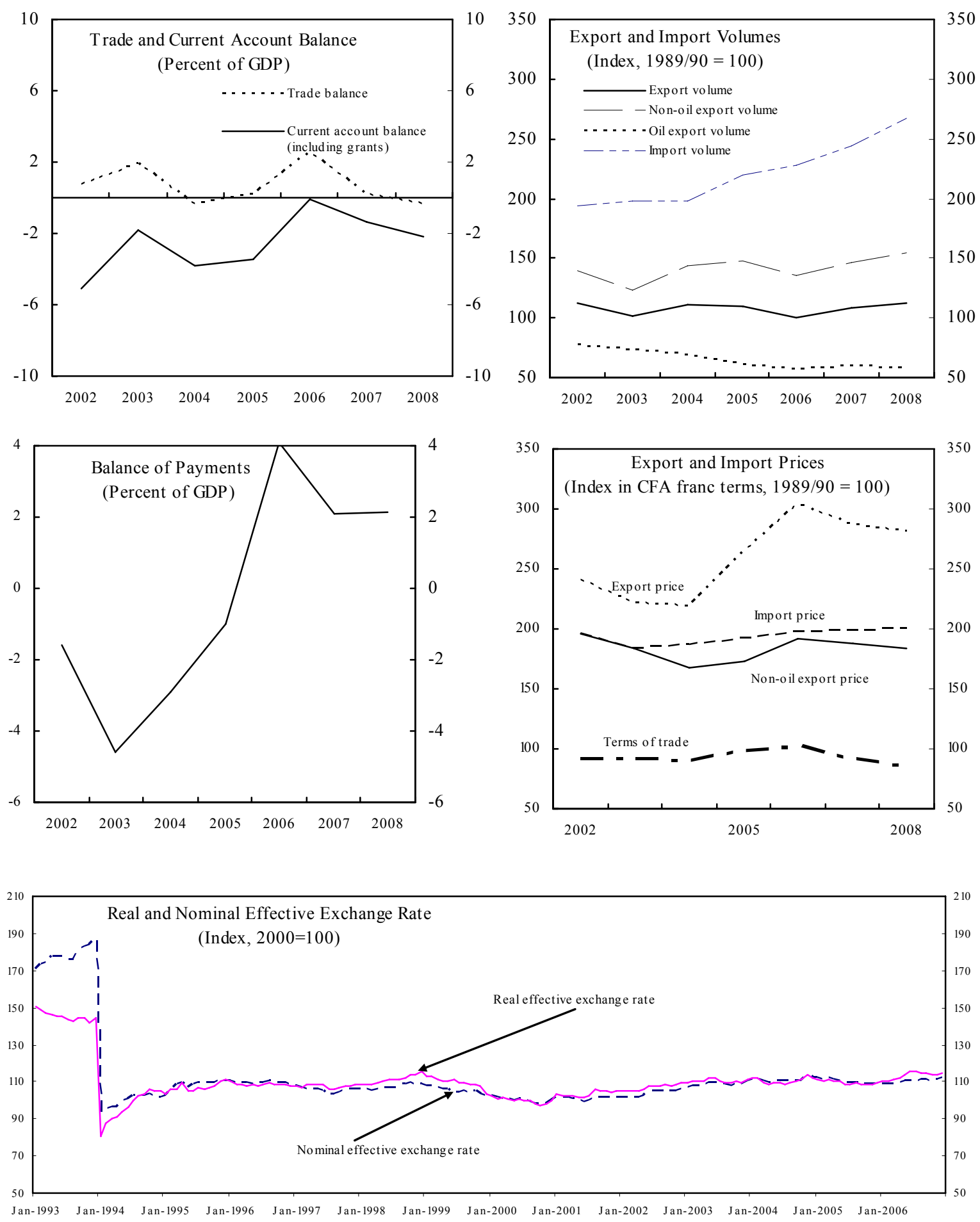

Sources: Cameroonian authorities; and IMF staff estimates and projections. 
Figure 3. Cameroon: Fiscal Developments and Prospects, 2002-08 (Percent of GDP)
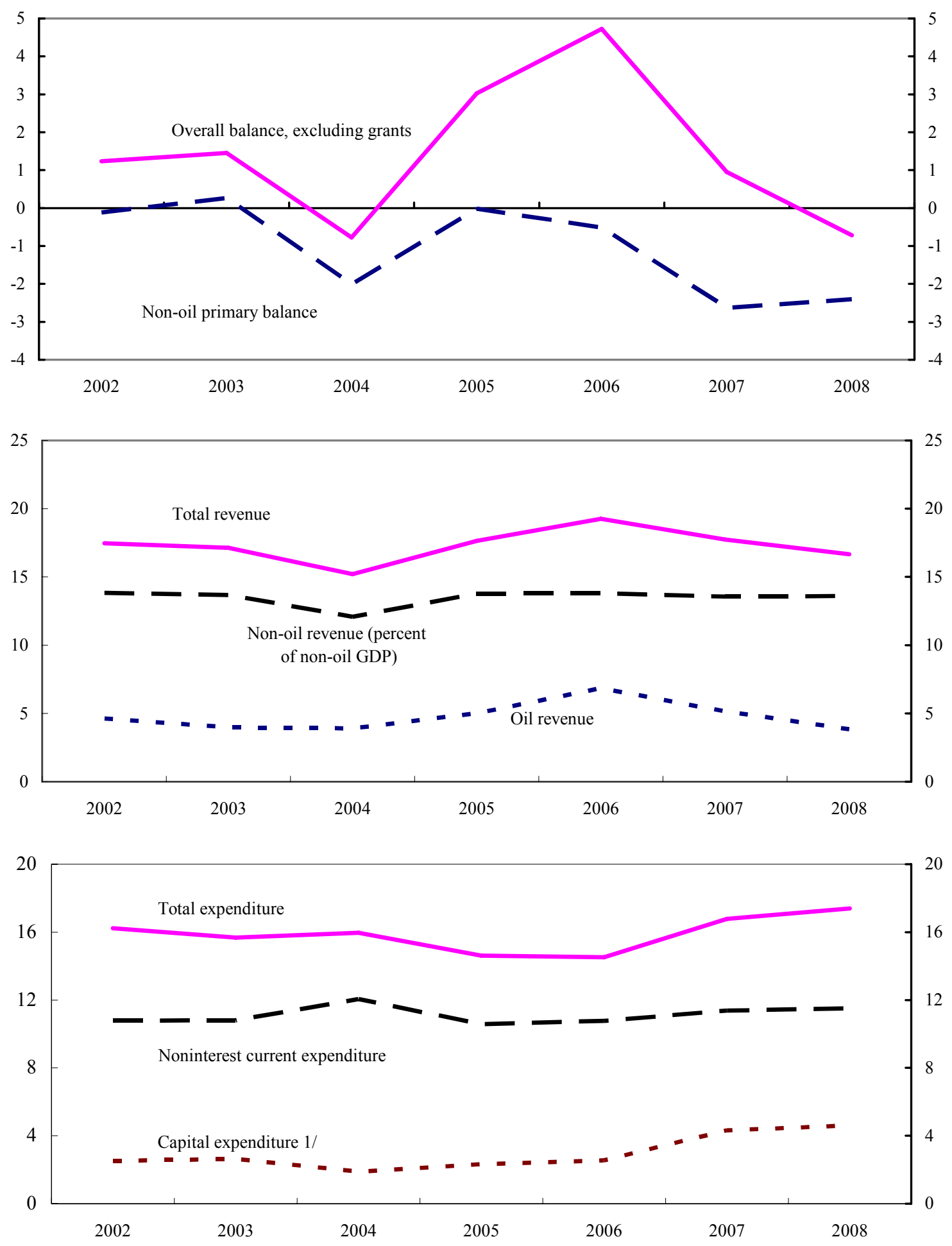

Sources: Cameroonian authorities; and IMF staff estimates and projections.

1/ Excluding restructuring expenditures. 
Table 1. Cameroon: Selected Economic and Financial Indicators, 2004-09

\begin{tabular}{|c|c|c|c|c|c|c|c|c|}
\hline & \multirow[t]{2}{*}{2004} & \multirow[t]{2}{*}{2005} & \multirow{2}{*}{$\frac{2006}{\text { Est. }}$} & \multicolumn{2}{|c|}{2007} & \multicolumn{2}{|c|}{2008} & \multirow{2}{*}{$\begin{array}{l}2009 \\
\text { Proj. }\end{array}$} \\
\hline & & & & Prog. & Proj. & Prog. & Proj. & \\
\hline & \multicolumn{8}{|c|}{ (Annual percentage changes, unless otherwise indicated) } \\
\hline \multicolumn{9}{|l|}{ National income and prices } \\
\hline GDP at constant prices & 3.7 & 2.3 & 3.2 & 4.2 & 2.7 & 4.9 & 4.4 & 4.6 \\
\hline Oil & -9.3 & -9.5 & 7.7 & 0.6 & -7.5 & 0.7 & 2.4 & -1.0 \\
\hline Nonoil & 4.9 & 3.2 & 2.9 & 4.4 & 3.4 & 5.2 & 4.5 & 4.9 \\
\hline GDP deflator & 1.5 & 2.6 & 3.9 & 1.2 & 1.8 & 1.9 & 2.0 & 0.6 \\
\hline Consumer prices (12-month average) & 0.3 & 2.0 & 5.1 & 1.8 & 1.5 & 1.8 & 3.3 & 2.0 \\
\hline Nominal GDP (billions of CFA francs) & 8,334 & 8,750 & 9,388 & 10,095 & 9,812 & 10,794 & 10,443 & 10,990 \\
\hline Oil & 541 & 734 & 955 & 727 & 841 & 799 & 870 & 771 \\
\hline Nonoil & 7,792 & 8,016 & 8,433 & 9,368 & 8,971 & 9,995 & 9,573 & 10,219 \\
\hline Oil output (thousands of barrels a day) & 89 & 82 & 87 & 88 & 84 & 86 & 85 & 83 \\
\hline \multicolumn{9}{|l|}{ External trade } \\
\hline Export volume & -0.7 & -8.2 & 8.1 & 4.2 & 2.8 & 3.6 & 4.0 & 4.0 \\
\hline Of which: Nonoil sector & 2.9 & -8.3 & 8.7 & 5.0 & 5.1 & 5.4 & 5.4 & 5.9 \\
\hline Import volume & 11.2 & 3.6 & 7.1 & 5.4 & 9.6 & 5.5 & 3.7 & 3.3 \\
\hline Average oil export price (U.S. dollars per barrel) & 34.9 & 50.4 & 61.6 & 50.0 & 62.8 & 54.8 & 65.0 & 59.3 \\
\hline Nominal effective exchange rate & 1.8 & -4.4 & 3.2 & $\ldots$ & $\ldots$ & $\ldots$ & $\ldots$ & $\ldots$ \\
\hline Real effective exchange rate & 0.1 & -3.5 & 4.5 & $\ldots$ & $\ldots$ & $\ldots$ & $\ldots$ & $\ldots$ \\
\hline Terms of trade & -2.2 & 16.8 & 11.8 & -14.6 & -6.1 & 0.4 & -3.1 & -6.3 \\
\hline Nonoil export price index (CFA francs) & -8.3 & 3.2 & 10.2 & -2.0 & -1.5 & -1.9 & -2.5 & -2.6 \\
\hline \multicolumn{9}{|l|}{ Money and credit (end of period) } \\
\hline Net domestic assets ${ }^{1}$ & 0.3 & -5.3 & -24.8 & -0.4 & -8.1 & -5.0 & -4.7 & -4.0 \\
\hline Net credit to the public sector ${ }^{1}$ & 0.1 & -8.7 & -21.7 & -3.8 & -9.6 & -9.2 & -8.0 & -7.1 \\
\hline Credit to the private sector & 1.4 & 10.9 & 3.2 & 6.8 & 3.0 & 8.5 & 6.5 & 6.2 \\
\hline Broad money (M2) & 7.3 & 4.2 & 9.3 & 6.7 & 3.7 & 7.7 & 7.2 & 5.2 \\
\hline Velocity (GDP/average M2) & 5.8 & 5.9 & 5.8 & 5.7 & 5.7 & 5.8 & 5.8 & 5.8 \\
\hline \multicolumn{9}{|l|}{ Central government operations } \\
\hline Total revenue & -0.4 & 21.8 & 17.1 & 1.6 & 1.2 & 7.8 & 7.4 & 5.6 \\
\hline Of which: Nonoil revenue & -0.7 & 17.3 & 5.5 & 12.1 & 7.3 & 7.8 & 6.7 & 8.2 \\
\hline \multirow[t]{2}{*}{ Total expenditure } & 9.2 & -4.0 & 6.7 & 16.3 & 17.1 & 7.3 & 6.8 & 9.0 \\
\hline & \multicolumn{8}{|c|}{ (Percent of GDP, unless otherwise indicated) } \\
\hline Gross national savings & 15.1 & 15.6 & 16.7 & 17.2 & 17.0 & 17.7 & 17.2 & 17.3 \\
\hline Gross domestic investment & 18.9 & 19.1 & 16.8 & 20.1 & 18.4 & 21.5 & 19.4 & 20.0 \\
\hline \multicolumn{9}{|l|}{ Central government operations } \\
\hline Total revenue (excluding grants) & 15.2 & 17.6 & 19.3 & 17.7 & 18.6 & 17.9 & 18.4 & 18.5 \\
\hline Oil revenue & 3.9 & 5.0 & 6.8 & 5.2 & 5.9 & 5.2 & 5.4 & 5.1 \\
\hline Nonoil revenue & 11.3 & 12.6 & 12.4 & 12.6 & 12.7 & 12.7 & 13.0 & 13.3 \\
\hline Nonoil revenue (percent of nonoil GDP) & 12.1 & 13.8 & 13.8 & 13.6 & 13.9 & 13.7 & 14.2 & 14.4 \\
\hline Total expenditure & 16.0 & 14.6 & 14.5 & 16.8 & 16.3 & 16.8 & 17.3 & 17.9 \\
\hline Noninterest expenditure ${ }^{2}$ & 13.1 & 12.6 & 12.6 & 14.6 & 14.6 & 14.7 & 15.2 & 16.0 \\
\hline Capital expenditure ${ }^{3}$ & 1.9 & 2.3 & 2.6 & 4.3 & 3.9 & 4.9 & 4.7 & 5.5 \\
\hline \multicolumn{9}{|l|}{ Fiscal balance (excluding net changes in arrears) } \\
\hline Excluding grants & -0.8 & 3.0 & 4.7 & 1.0 & 2.4 & 1.0 & 1.1 & 0.5 \\
\hline Including grants & -0.5 & 3.6 & 33.1 & 2.3 & 3.9 & 2.1 & 1.9 & 1.5 \\
\hline Primary balance ${ }^{4}$ & 1.9 & 5.0 & 6.3 & 2.5 & 3.7 & 3.0 & 2.8 & 2.3 \\
\hline Nonoil primary balance (percent of nonoil GDP) ${ }^{4}$ & -2.1 & 0.0 & -0.6 & -2.8 & -2.4 & -2.4 & -2.9 & -3.0 \\
\hline \multicolumn{9}{|l|}{ External sector } \\
\hline Current account balance (including grants) & -3.8 & -3.4 & -0.1 & -2.8 & -1.4 & -3.9 & -2.2 & -2.7 \\
\hline Gross official reserves & 9.3 & 10.8 & 14.3 & 8.7 & 16.9 & 13.1 & 20.3 & 22.0 \\
\hline Stock of external debt ${ }^{3}$ & 44.2 & 36.7 & 6.1 & 5.6 & 6.2 & 6.7 & 7.2 & 8.2 \\
\hline Stock of public debt & 61.3 & 51.5 & 15.7 & 12.4 & 13.3 & 11.7 & 12.5 & 13.2 \\
\hline & & cent of exp & rts of goo & s and serv & es, unles: & otherwise & dicated) & \\
\hline NPV of external debt after HIPC, bilateral relief beyond HIPC, and MDRI ${ }^{\circ}$ & 26.3 & 11.0 & 15.8 & 12.3 & 16.9 & 15.8 & 20.0 & 24.1 \\
\hline External debt service $^{7}$ & 7.1 & 6.7 & 2.6 & 1.7 & 1.4 & 1.7 & 1.5 & 1.6 \\
\hline External debt service (as a percent of government revenue) ${ }^{7}$ & 10.8 & 9.2 & 4.5 & 2.7 & 2.4 & 2.8 & 2.6 & 2.6 \\
\hline
\end{tabular}

Sources: Cameroonian authorities; and IMF staff estimates and projections.

1 Percent of broad money at the beginning of the period.

${ }^{2}$ Excluding foreign-financed investment, restructuring expenditure, and separation grants.

${ }^{3}$ Excluding restructuring expenditure.

${ }^{4}$ Excluding grants, interest, and foreign-financed capital expenditures.

${ }^{5}$ Assumes cancellation of C2D debt in 2006.

${ }^{6} \mathrm{NPV}$ s calculated using the LIC DSA methodology.

${ }^{7}$ Actual payments through 2006, and after all expected debt relief thereafter. 
Table 2. Cameroon: Balance of Payments, 2004-09

\begin{tabular}{|c|c|c|c|c|c|c|c|c|}
\hline & \multirow[t]{2}{*}{2004} & \multirow[t]{2}{*}{2005} & \multirow{2}{*}{$\frac{2006}{\text { Est. }}$} & \multicolumn{2}{|c|}{2007} & \multicolumn{2}{|c|}{2008} & \multirow{2}{*}{$\frac{2009}{\text { Proj. }}$} \\
\hline & & & & Prog. & Proj. & Prog. & Proj. & \\
\hline & \multicolumn{8}{|c|}{ (Billions of CFA francs) } \\
\hline Current account balance & -319 & -299 & -9 & -285 & -137 & -417 & -228 & -295 \\
\hline Trade balance & -30 & 19 & 235 & -100 & 14 & -132 & -41 & -150 \\
\hline Exports, f.o.b. & 1,362 & 1,509 & 1,877 & 1,651 & 1,819 & 1,733 & 1,850 & 1,773 \\
\hline Oil and oil products & 574 & 763 & 983 & 784 & 893 & 837 & 899 & 792 \\
\hline Nonoil sector & 789 & 747 & 895 & 867 & 925 & 896 & 951 & 981 \\
\hline Imports, f.o.b. & $-1,392$ & $-1,490$ & $-1,642$ & $-1,751$ & $-1,805$ & $-1,865$ & $-1,891$ & $-1,923$ \\
\hline Services (net) & -156 & -189 & -245 & -302 & -297 & -370 & -354 & -358 \\
\hline Income (net) & -212 & -243 & -131 & -90 & -51 & -109 & -28 & 4 \\
\hline Of which: Interest due on public debt & -139 & -112 & -73 & -37 & -37 & -36 & -32 & -32 \\
\hline Transfers (net) & 79 & 114 & 132 & 207 & 198 & 194 & 195 & 209 \\
\hline Inflows & 91 & 127 & 145 & 221 & 214 & 206 & 211 & 222 \\
\hline Outflows & -11 & -13 & -13 & -14 & -16 & -11 & -16 & -13 \\
\hline Capital and financial account balance & 75 & 214 & 392 & 394 & 328 & 647 & 440 & 471 \\
\hline Capital account & 6 & 6 & 2,610 & 12 & 39 & 11 & 11 & 11 \\
\hline Capital transfers & 6 & 6 & 157 & 12 & 23 & 11 & 11 & 11 \\
\hline Of which: Other transfers (MDRI grant-IMF) & ... & $\ldots$ & 132 & 0 & 0 & 0 & 0 & 0 \\
\hline Debt forgiveness & 0 & 0 & 2,452 & 0 & 16 & 0 & 0 & 0 \\
\hline Financial account & 69 & 208 & $-2,218$ & 382 & 289 & 636 & 429 & 460 \\
\hline Official capital & -191 & -236 & $-2,558$ & 39 & 0 & 93 & 102 & 97 \\
\hline Long-term borrowing & 104 & 38 & 63 & 124 & 87 & 175 & 173 & 168 \\
\hline Principal not yet due rescheduled & 0 & 0 & 14 & 0 & 0 & 0 & 0 & 0 \\
\hline Amortization & -296 & -273 & -169 & -84 & -71 & -82 & -71 & -71 \\
\hline Principal not yet due & 0 & 0 & $-2,466$ & 0 & -16 & 0 & 0 & 0 \\
\hline Private capital (net) & 260 & 443 & 340 & 342 & 289 & 543 & 327 & 363 \\
\hline Overall balance & -244 & -86 & 382 & 109 & 191 & 230 & 212 & 176 \\
\hline Financing & 244 & 86 & -382 & -109 & -191 & -230 & -212 & -176 \\
\hline Bank of Central African States & -87 & -140 & -475 & -111 & -191 & -231 & -212 & -176 \\
\hline Use of IMF credit (net) & -15 & -19 & -137 & 4 & 6 & 4 & 4 & 0 \\
\hline Use of Fund credit & -15 & -19 & -137 & 4 & 6 & 4 & 4 & 0 \\
\hline Other reserves (net) & -72 & -121 & -338 & -115 & -197 & -235 & -216 & -176 \\
\hline Exceptional financing (debt relief) ${ }^{1}$ & 297 & 237 & 89 & 0 & 0 & 0 & 0 & 0 \\
\hline Net change in arrears & 34 & -11 & 3 & 1 & 0 & 0 & 0 & 0 \\
\hline Financing need ${ }^{2}$ & 0 & 0 & 0 & 1 & 0 & 1 & 0 & 0 \\
\hline \multirow[t]{2}{*}{ Remaining financing gap } & 0 & 0 & 0 & 0 & 0 & 0 & 0 & 0 \\
\hline & \multicolumn{8}{|c|}{ (Percent of GDP) } \\
\hline Trade balance & -0.4 & 0.2 & 2.5 & -1.0 & 0.1 & -1.2 & -0.4 & -1.4 \\
\hline \multicolumn{9}{|l|}{ Current account balance } \\
\hline Excluding grants & -4.0 & -3.9 & -0.7 & -4.0 & -2.6 & -4.8 & -3.1 & -3.6 \\
\hline Including grants & -3.8 & -3.4 & -0.1 & -2.8 & -1.4 & -3.9 & -2.2 & -2.7 \\
\hline Overall balance & -2.9 & -1.0 & 4.1 & 1.1 & 2.0 & 2.1 & 2.0 & 1.6 \\
\hline & \multicolumn{8}{|c|}{ (Percentage change, unless otherwise indicated) } \\
\hline Export volume & -0.7 & -8.2 & 8.1 & 4.2 & 2.8 & 3.6 & 4.0 & 4.0 \\
\hline Oil sector & -10.4 & -7.9 & 6.4 & 1.9 & -4.1 & -2.0 & -1.0 & -3.1 \\
\hline Nonoil sector & 2.9 & -8.3 & 8.7 & 5.0 & 5.1 & 5.4 & 5.4 & 5.9 \\
\hline Import volume & 11.2 & 3.6 & 7.1 & 5.4 & 9.6 & 5.5 & 3.7 & 3.3 \\
\hline Of which: Nonoil sector & 7.8 & 2.2 & 2.8 & 7.2 & 8.5 & 8.7 & 3.9 & 4.9 \\
\hline Terms of trade & -2.2 & 16.8 & 11.8 & -14.6 & -6.1 & 0.4 & -3.1 & -6.3 \\
\hline Nonoil export price index (CFA francs) & -8.3 & 3.2 & 10.2 & -2.0 & -1.5 & -1.9 & -2.5 & -2.6 \\
\hline Import price index (CFA francs) & 1.1 & 3.3 & 2.9 & 1.6 & 0.3 & 0.9 & 1.0 & -1.6 \\
\hline Exchange rate (CFA francs per U.S. dollar) & 528.0 & 527.3 & 522.8 & $\ldots$ & $\ldots$ & $\ldots$ & $\ldots$ & $\ldots$ \\
\hline
\end{tabular}


Table 3. Cameroon: Monetary Survey, December 2004-December 2008

(Billions of CFA francs, unless otherwise noted)

\begin{tabular}{|c|c|c|c|c|c|c|c|c|}
\hline & \multirow{3}{*}{$\frac{2004}{\text { Dec. }}$} & \multirow{3}{*}{$\frac{2005}{\text { Dec. }}$} & \multirow{3}{*}{$\frac{2006}{\text { Dec. }}$} & \multicolumn{4}{|c|}{2007} & \multirow{3}{*}{$\begin{array}{l}\frac{2008}{\text { Dec. }} \\
\text { Proj. }\end{array}$} \\
\hline & & & & \multicolumn{2}{|c|}{ March } & \multicolumn{2}{|c|}{ Dec. } & \\
\hline & & & & Prog. & Est. & Prog. & Proj. & \\
\hline Net foreign assets & 357 & 500 & 1,034 & 1,064 & 1,137 & 1,155 & 1,235 & 1,447 \\
\hline Bank of Central African States (BEAC) & 242 & 382 & 856 & 884 & 957 & 967 & 1,048 & 1,260 \\
\hline Commercial banks & 115 & 118 & 178 & 180 & 180 & 188 & 188 & 188 \\
\hline Net domestic assets & 1,148 & 1,069 & 679 & 691 & 587 & 673 & 541 & 457 \\
\hline Domestic credit & 1,231 & 1,174 & 863 & 875 & 805 & 856 & 725 & 640 \\
\hline Net claims on the public sector & 469 & 338 & -2 & -25 & -62 & -68 & -166 & -308 \\
\hline Net credit to the central government & 374 & 238 & -90 & -113 & -140 & -156 & -255 & -397 \\
\hline Claims & 572 & 461 & 301 & 303 & 175 & 305 & 307 & 310 \\
\hline Deposits & -198 & -223 & -391 & -416 & -315 & -461 & -561 & -707 \\
\hline Credit to autonomous agencies & 15 & 22 & 17 & 17 & 15 & 17 & 17 & 17 \\
\hline Credit to public enterprises & 81 & 78 & 71 & 71 & 63 & 71 & 71 & 71 \\
\hline Credit to financial institutions & 11 & 4 & 6 & 6 & 26 & 6 & 6 & 6 \\
\hline Credit to the private sector & 750 & 832 & 859 & 894 & 841 & 918 & 885 & 943 \\
\hline Other items (net) & -83 & -106 & -184 & -184 & -218 & -184 & -184 & -184 \\
\hline Money and quasi money & 1,505 & 1,568 & 1,713 & 1,756 & 1,724 & 1,828 & 1,776 & 1,904 \\
\hline Currency outside banks & 324 & 273 & 259 & 251 & 259 & 265 & 262 & 270 \\
\hline Deposits & 1,181 & 1,295 & 1,455 & 1,505 & 1,465 & 1,562 & 1,514 & 1,634 \\
\hline \multicolumn{9}{|l|}{ Memorandum items: } \\
\hline \multicolumn{9}{|c|}{ Contribution to the growth of broad money (percentage points) } \\
\hline Net foreign assets & 7.8 & 9.5 & 34.1 & 30.2 & 34.8 & 7.1 & 11.8 & 11.9 \\
\hline Net domestic assets & 2.5 & -5.3 & -24.8 & -18.4 & -25.1 & -0.4 & -8.1 & -4.7 \\
\hline Of which: credit to the central government & 1.6 & -9.0 & -20.9 & -18.9 & -20.6 & -3.8 & -9.6 & -8.0 \\
\hline Private sector credit (annual percentage change) & 1.4 & 10.9 & 3.2 & 5.7 & -0.6 & 6.8 & 3.0 & 6.5 \\
\hline Broad money (annual percentage change) & 7.3 & 4.2 & 9.3 & 11.8 & 9.7 & 6.7 & 3.7 & 7.2 \\
\hline Currency & 9.2 & -15.6 & -5.4 & 2.5 & 5.9 & 2.6 & 1.5 & 2.9 \\
\hline Deposits & 6.7 & 9.6 & 12.4 & 13.5 & 10.4 & 7.4 & 4.1 & 7.9 \\
\hline Claims on government/domestic credit ratio & 30.4 & 20.3 & -10.5 & -12.9 & -17.4 & -18.2 & -35.2 & -62.0 \\
\hline Currency outside banks/deposit ratio & 27.4 & 21.1 & 17.8 & 16.7 & 17.7 & 17.0 & 17.3 & 16.5 \\
\hline Velocity (nonoil GDP/average M2) & 5.4 & 5.4 & 5.2 & $\ldots$ & $\ldots$ & 5.4 & 5.3 & 5.3 \\
\hline Velocity (GDP/average M2) & 5.8 & 5.9 & 5.8 & $\ldots$ & $\ldots$ & 5.7 & 5.7 & 5.8 \\
\hline Net claims on the public sector ${ }^{1}$ & 341 & 205 & -90 & -113 & -140 & -156 & -255 & -397 \\
\hline
\end{tabular}

Sources: BEAC; and IMF staff estimates and projections.

${ }^{1}$ In billions of CFA francs, using the definition of the BEAC, which includes deposits of public enterprises and autonomous agencies. 
Table 4. Cameroon: Central Government Operations, 2004-09

(Billions of CFA francs)

\begin{tabular}{|c|c|c|c|c|c|c|c|c|}
\hline & 2004 & 2005 & 2006 & 20 & & & & 2009 \\
\hline & & & & Prog. & Proj. & Prog. & Proj. & Proj. \\
\hline Total revenue and grants & 1,286 & 1,590 & 4,472 & 1,925 & 1,979 & 2,044 & 2,012 & 2,140 \\
\hline Total revenue & 1,267 & 1,543 & 1,808 & 1,791 & 1,830 & 1,930 & 1,924 & 2,032 \\
\hline Oil sector revenue & 325 & 439 & 643 & 521 & 580 & 560 & 568 & 565 \\
\hline Nonoil sector revenue & 942 & 1,104 & 1,165 & 1,270 & 1,250 & 1,370 & 1,356 & 1,467 \\
\hline Total grants & 19 & 47 & 2,664 & 134 & 149 & 114 & 89 & 108 \\
\hline Total expenditure & 1,331 & 1,278 & 1,364 & 1,695 & 1,597 & 1,818 & 1,811 & 1,973 \\
\hline Current expenditure & 1,169 & 1,055 & 1,097 & 1,198 & 1,188 & 1,271 & 1,273 & 1,348 \\
\hline Wages and salaries & 450 & 414 & 419 & 479 & 465 & 500 & 510 & 550 \\
\hline Goods and services & 414 & 337 & 381 & 466 & 457 & 512 & 501 & 554 \\
\hline Debt-relief financed & 33 & 22 & 19 & 59 & 52 & 51 & 51 & 50 \\
\hline Subsidies and transfers & 141 & 175 & 211 & 205 & 216 & 208 & 215 & 197 \\
\hline of which: fuel subsidies & $\ldots$ & 17 & 22 & 25 & 25 & 25 & 25 & 20 \\
\hline Pensions & 64 & 77 & 72 & 92 & 87 & 95 & 95 & 97 \\
\hline Interest due & 164 & 129 & 87 & 49 & 50 & 50 & 47 & 47 \\
\hline External & 138 & 111 & 72 & 35 & 37 & 35 & 32 & 32 \\
\hline Domestic & 26 & 18 & 15 & 14 & 14 & 15 & 15 & 16 \\
\hline Capital expenditure & 167 & 206 & 271 & 496 & 410 & 547 & 538 & 625 \\
\hline Domestic investment & 90 & 159 & 177 & 327 & 294 & 369 & 359 & 455 \\
\hline Own-resource financed & 80 & 107 & 143 & 178 & 188 & 226 & 216 & 290 \\
\hline Debt-relief financed & 10 & 52 & 34 & 149 & 107 & 143 & 143 & 165 \\
\hline Foreign-financed investment & 67 & 44 & 64 & 110 & 84 & 158 & 135 & 150 \\
\hline Rehabilitation and participation & 10 & 3 & 31 & 60 & 32 & 20 & 44 & 20 \\
\hline Net lending & 0 & 0 & 0 & 0 & 0 & 0 & 0 & 0 \\
\hline Unclassified expenditure & -5 & 17 & -5 & 0 & -1 & 0 & 0 & 0 \\
\hline Overall balance, excluding net change in arrears & & & & & & & & \\
\hline Excluding grants & -64 & 265 & 444 & 97 & 233 & 112 & 113 & 59 \\
\hline Including grants & -45 & 312 & 3,108 & 230 & 382 & 226 & 202 & 168 \\
\hline Net change in arrears & 31 & -73 & -170 & -59 & -71 & -35 & -35 & -22 \\
\hline External & 34 & -11 & 3 & 1 & 0 & 0 & 0 & 0 \\
\hline Domestic & -4 & -62 & -173 & -60 & -71 & -35 & -35 & -22 \\
\hline Overall balance, cash basis & & & & & & & & \\
\hline Excluding grants & -34 & 192 & 274 & 37 & 161 & 76 & 78 & 37 \\
\hline Including grants & -15 & 239 & 2,938 & 171 & 310 & 191 & 167 & 146 \\
\hline Financing & 15 & -239 & $-2,938$ & -172 & -310 & -192 & -167 & -146 \\
\hline External financing, net & 51 & -35 & $-2,476$ & 13 & -27 & 66 & 74 & 68 \\
\hline Amortization & -296 & -273 & $-2,635$ & -84 & -87 & -82 & -71 & -71 \\
\hline Drawings & 94 & 38 & 38 & 97 & 61 & 148 & 146 & 139 \\
\hline Project financing & 0 & 38 & 38 & 97 & 61 & 148 & 125 & 139 \\
\hline Program financing (loans) & 43 & 0 & 0 & 0 & 0 & 0 & 21 & 0 \\
\hline Debt rescheduling & 0 & 0 & 14 & 0 & 0 & 0 & 0 & 0 \\
\hline Exceptional financing & 252 & 200 & 107 & 0 & 0 & 0 & 0 & 0 \\
\hline Domestic financing, net & -36 & -204 & -462 & -185 & -284 & -258 & -241 & -214 \\
\hline Banking system & 13 & -139 & -305 & -66 & -164 & -168 & -142 & -135 \\
\hline Banking system, excluding HIPC and C2D & -7 & -151 & -238 & -58 & -78 & -158 & -134 & -161 \\
\hline Net HIPC flows & 20 & 12 & -2 & 16 & -23 & -1 & 2 & 26 \\
\hline Net C2D flows & $\ldots$ & $\ldots$ & -65 & -23 & -63 & 9 & -10 & 0 \\
\hline Amortization & -33 & -69 & -159 & -110 & -110 & -79 & -79 & -59 \\
\hline Non-bank financing & -16 & 5 & 2 & 0 & 0 & 0 & 0 & 0 \\
\hline Reserves & 0 & 0 & 0 & -10 & -10 & -10 & -20 & -20 \\
\hline Memorandum items: & & & & & & & & \\
\hline HIPC-financed spending & 43 & 75 & 52 & 100 & 73 & 78 & 78 & 95 \\
\hline C2D-financed spending & 0 & 0 & 0 & 70 & 62 & 80 & 80 & 90 \\
\hline MDRI-financed spending & 0 & 0 & 0 & 37 & 23 & 35 & 36 & 31 \\
\hline Nonoil primary balance (program definition) ${ }^{1}$ & -106 & 76 & 36 & -36 & -46 & -62 & -71 & -105 \\
\hline
\end{tabular}

Sources: Cameroonian authorities; and IMF staff estimates and projections.

${ }^{1}$ Excludes restructuring, HIPC- and C2D-financed expenditures, in addition to grants, interest, and foreign-financed capital expenditure. 
Table 5. Cameroon: Selected Fiscal Indicators, 2004-09

(Percent of GDP, unless otherwise indicated)

\begin{tabular}{|c|c|c|c|c|c|c|c|c|}
\hline & \multirow[t]{2}{*}{2004} & \multirow[t]{2}{*}{2005} & \multirow[t]{2}{*}{2006} & \multicolumn{2}{|c|}{2007} & \multicolumn{2}{|c|}{2008} & \multirow{2}{*}{$\frac{2009}{\text { Proj. }}$} \\
\hline & & & & Prog. & Proj. & Prog. & Proj. & \\
\hline Total revenue and grants & 15.4 & 18.2 & 47.6 & 19.1 & 20.2 & 18.9 & 19.3 & 19.5 \\
\hline Total revenue & 15.2 & 17.6 & 19.3 & 17.7 & 18.6 & 17.9 & 18.4 & 18.5 \\
\hline Oil sector revenue & 3.9 & 5.0 & 6.8 & 5.2 & 5.9 & 5.2 & 5.4 & 5.1 \\
\hline Nonoil sector revenue & 11.3 & 12.6 & 12.4 & 12.6 & 12.7 & 12.7 & 13.0 & 13.3 \\
\hline Total grants & 0.2 & 0.5 & 28.4 & 1.3 & 1.5 & 1.1 & 0.8 & 1.0 \\
\hline Total expenditure & 16.0 & 14.6 & 14.5 & 16.8 & 16.3 & 16.8 & 17.3 & 17.9 \\
\hline Current expenditure & 14.0 & 12.1 & 11.7 & 11.9 & 12.1 & 11.8 & 12.2 & 12.3 \\
\hline Wages and salaries & 5.4 & 4.7 & 4.5 & 4.7 & 4.7 & 4.6 & 4.9 & 5.0 \\
\hline Goods and services & 5.0 & 3.8 & 4.1 & 4.6 & 4.7 & 4.7 & 4.8 & 5.0 \\
\hline of which: debt-relief financed & 0.4 & 0.3 & 0.2 & 0.6 & 0.5 & 0.5 & 0.5 & 0.5 \\
\hline Subsidies and transfers & 1.7 & 2.0 & 2.2 & 2.0 & 2.2 & 1.9 & 2.1 & 1.8 \\
\hline of which: fuel subsidies & $\ldots$ & 0.2 & 0.2 & 0.2 & 0.3 & 0.2 & 0.2 & 0.2 \\
\hline Pensions & 0.8 & 0.9 & 0.8 & 0.9 & 0.9 & 0.9 & 0.9 & 0.9 \\
\hline Interest due & 2.0 & 1.5 & 0.9 & 0.5 & 0.5 & 0.5 & 0.4 & 0.4 \\
\hline External & 1.7 & 1.3 & 0.8 & 0.3 & 0.4 & 0.3 & 0.3 & 0.3 \\
\hline Domestic & 0.3 & 0.2 & 0.2 & 0.1 & 0.1 & 0.1 & 0.1 & 0.1 \\
\hline Capital expenditure & 2.0 & 2.4 & 2.9 & 4.9 & 4.2 & 5.1 & 5.2 & 5.7 \\
\hline Domestic investment & 1.1 & 1.8 & 1.9 & 3.2 & 3.0 & 3.4 & 3.4 & 4.1 \\
\hline Own-resource financed & 1.0 & 1.2 & 1.5 & 1.8 & 1.9 & 2.1 & 2.1 & 2.6 \\
\hline Debt-relief financed & 0.1 & 0.6 & 0.4 & 1.5 & 1.1 & 1.3 & 1.4 & 1.5 \\
\hline Foreign-financed investment & 0.8 & 0.5 & 0.7 & 1.1 & 0.9 & 1.5 & 1.3 & 1.4 \\
\hline Rehabilitation and participation & 0.1 & 0.0 & 0.3 & 0.6 & 0.3 & 0.2 & 0.4 & 0.2 \\
\hline Net lending & 0.0 & 0.0 & 0.0 & 0.0 & 0.0 & 0.0 & 0.0 & 0.0 \\
\hline Unclassified expenditure & -0.1 & 0.2 & -0.1 & 0.0 & 0.0 & 0.0 & 0.0 & 0.0 \\
\hline \multicolumn{9}{|l|}{ Overall balance, excluding net change in arrears } \\
\hline Excluding grants & -0.8 & 3.0 & 4.7 & 1.0 & 2.4 & 1.0 & 1.1 & 0.5 \\
\hline Including grants & -0.5 & 3.6 & 33.1 & 2.3 & 3.9 & 2.1 & 1.9 & 1.5 \\
\hline Net change in arrears & 0.4 & -0.8 & -1.8 & -0.6 & -0.7 & -0.3 & -0.3 & -0.2 \\
\hline External & 0.4 & -0.1 & 0.0 & 0.0 & 0.0 & 0.0 & 0.0 & 0.0 \\
\hline Domestic & 0.0 & -0.7 & -1.8 & -0.6 & -0.7 & -0.3 & -0.3 & -0.2 \\
\hline \multicolumn{9}{|l|}{ Overall balance, cash basis } \\
\hline Excluding grants & -0.4 & 2.2 & 2.9 & 0.4 & 1.6 & 0.7 & 0.7 & 0.3 \\
\hline Including grants & -0.2 & 2.7 & 31.3 & 1.7 & 3.2 & 1.8 & 1.6 & 1.3 \\
\hline Financing & 0.2 & -2.7 & -31.3 & -1.7 & -3.2 & -1.8 & -1.6 & -1.3 \\
\hline External financing, net & 0.6 & -0.4 & -26.4 & 0.1 & -0.3 & 0.6 & 0.7 & 0.6 \\
\hline Amortization & -3.5 & -3.1 & -28.1 & -0.8 & -0.9 & -0.8 & -0.7 & -0.6 \\
\hline Drawings & 1.1 & 0.4 & 0.4 & 1.0 & 0.6 & 1.4 & 1.4 & 1.3 \\
\hline Project financing & 0.0 & 0.4 & 0.4 & 1.0 & 0.6 & 1.4 & 1.2 & 1.3 \\
\hline Program financing (loans) & 0.5 & 0.0 & 0.0 & 0.0 & 0.0 & 0.0 & 0.2 & 0.0 \\
\hline Debt rescheduling & 0.0 & 0.0 & 0.2 & 0.0 & 0.0 & 0.0 & 0.0 & 0.0 \\
\hline Exceptional financing & 3.0 & 2.3 & 1.1 & 0.0 & 0.0 & 0.0 & 0.0 & 0.0 \\
\hline Domestic financing, net & -0.4 & -2.3 & -4.9 & -1.8 & -2.9 & -2.4 & -2.3 & -1.9 \\
\hline Banking system & 0.2 & -1.6 & -3.2 & -0.7 & -1.7 & -1.6 & -1.4 & -1.2 \\
\hline Banking system, excluding HIPC and C2D & -0.1 & -1.7 & -2.5 & -0.6 & -0.8 & -1.5 & -1.3 & -1.5 \\
\hline Net HIPC flows & 0.2 & 0.1 & 0.0 & 0.2 & -0.2 & 0.0 & 0.0 & 0.2 \\
\hline Net C2D flows & $\ldots$ & $\ldots$ & -0.7 & -0.2 & -0.6 & 0.1 & -0.1 & 0.0 \\
\hline Amortization & -0.4 & -0.8 & -1.7 & -1.1 & -1.1 & -0.7 & -0.8 & -0.5 \\
\hline Nonbank financing & -0.2 & 0.1 & 0.0 & 0.0 & 0.0 & 0.0 & 0.0 & 0.0 \\
\hline Reserves & 0.0 & 0.0 & 0.0 & -0.1 & -0.1 & -0.1 & -0.2 & -0.2 \\
\hline \multicolumn{9}{|l|}{ Memorandum items: } \\
\hline Nonoil revenue $^{1}$ & 12.1 & 13.8 & 13.8 & 13.6 & 13.9 & 13.7 & 14.2 & 14.4 \\
\hline Nonoil primary balance (program definition) $)^{1,2}$ & -1.4 & 1.0 & 0.4 & -0.4 & -0.5 & -0.6 & -0.7 & -1.0 \\
\hline
\end{tabular}

Sources: Cameroonian authorities; and IMF staff estimates and projections.

${ }^{1}$ Percent of nonoil GDP.

${ }^{2}$ Excludes restructuring, HIPC- and C2D-financed expenditures, in addition to grants, interest, and foreign-financed capital expenditures. 
Table 6. Cameroon: Indicators of IMF Credit, 2004-08

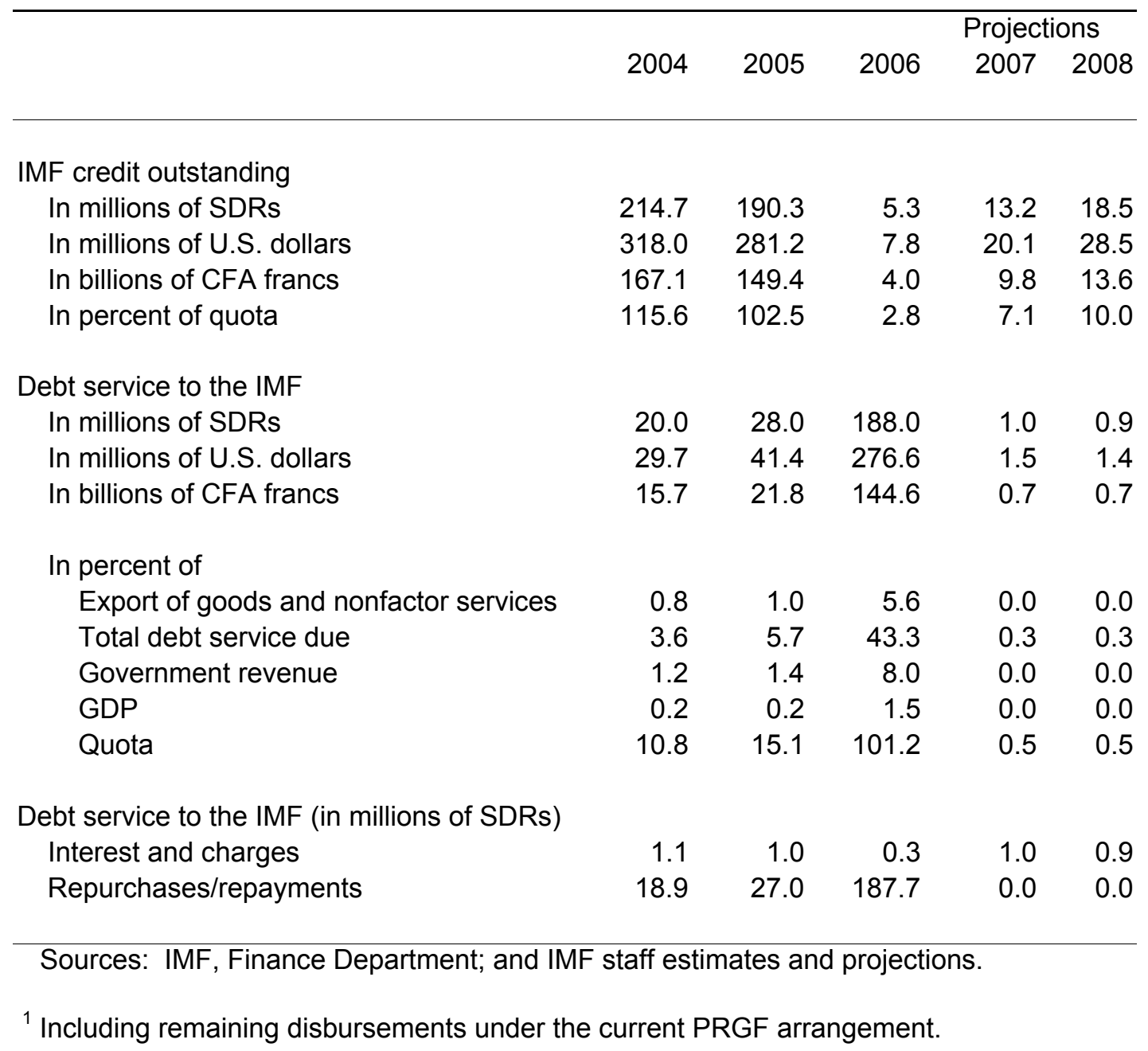


Table 7. Cameroon: Fund Disbursements and Timing of Reviews Under the PRGF, 2007-08

\begin{tabular}{llc}
\hline Date of First Availability & \multicolumn{1}{c}{ Conditions } & \multicolumn{1}{c}{$\begin{array}{c}\text { Amount } \\
\text { (Millions of SDRs) }\end{array}$} \\
\hline October 15, 2007 & $\begin{array}{l}\text { Completion of fourth review (end-June 2007 } \\
\text { quantitative and structural performance } \\
\text { criteria) }\end{array}$ & 2.65 \\
April 15, 2008 & $\begin{array}{l}\text { Completion of fifth review (end-December } \\
2007 \text { quantitative and structural performance } \\
\text { criteria) }\end{array}$ & 2.65 \\
September 15, 2008 & $\begin{array}{l}\text { Completion of sixth review (end-June 2008 } \\
\text { quantitative and structural performance } \\
\text { criteria) }\end{array}$ & \\
\hline
\end{tabular}


November 29, 2007

Mr. Dominique Strauss-Kahn

Managing Director

International Monetary Fund

70019 th Street, N.W.

Washington, D.C. 20431

U.S.A

Dear Mr. Strauss-Kahn:

1. During the first half of 2007, the government continued its efforts to consolidate the macroeconomic framework and implement structural reforms in the context of its economic program supported by the International Monetary Fund (IMF) under the Poverty Reduction and Growth Facility (PRGF).

2. The government remains convinced that the continued implementation of the economic measures and policies it has undertaken under the PRGF will enable it to build on the results already obtained and combat poverty more effectively, while improving prospects for growth. The recent cabinet reshuffle reflects the government's strengthened commitment to accelerating economic growth and improving the living conditions of the population.

3. The government's efforts to pursue fiscal consolidation during the period spanning January to June 2007 enabled it to meet most of the program's quantitative criteria and benchmarks at end-June 2007.

4. The implementation of structural reforms in the areas of public finance and transparency also moved forward. In particular, court decisions and administrative sanctions issued against civil servants in the context of the anti-corruption campaign were published on the Prime Minister's web site (www.spm.gov.cm). The second report prepared in the context of the Extractive Industries Transparency Initiative (EITI), covering 2005, was also published on the government's website.

5. Delays occurred in other areas, however, particularly in the financial sector, the civil service, and public enterprises. The government took all measures necessary to compensate 
for these delays, but nonetheless a waiver is requested for the nonobservance of the performance criterion related to the preparatory work for the establishment of a financial subsidiary for CAMPOST. This process has proven more complex than expected, given the legal status of CAMPOST and the nature of its activities.

6. The government is aware of the importance of improving the business climate and, in particular, access to credit to boost economic growth and sustainably reduce poverty. To this end, it prepared a business plan evaluating the different options for expanding the financial services offered by CAMPOST throughout the country and is committed to continuing its close supervision of this institution's financial activities to protect its customers' savings.

7. The macroeconomic policies and objectives for the third year of the program and over the medium term remain consistent with the general framework underlying the government's three-year PRGF-supported program. Thus, the attached Memorandum of Economic and Financial Policies (MEFP) supplements the MEFP attached to the letter of intent of May 29, 2007. It evaluates the implementation of the government's economic program during the first half of 2007, and presents the economic policies and objectives for the period spanning July 2007 to June 2008 .

8. For purposes of the execution of its economic and financial program, the government has set ambitious medium-term objectives, consistent with the macroeconomic framework of the three-year program. In this context, particular emphasis will continue to be placed on enhancing fiscal management, mobilizing nonoil revenues, fighting corruption, and improving the quality of public investment.

9. The government is convinced that the economic and financial policies described in the attached MEFP will help to achieve the objectives of its July 2007-July 2008 economic program. However, it is prepared to take any further measures that may become appropriate for this purpose. The government will consult with the IMF on the adoption of these measures and in advance of revisions to the policies contained in the MEFP, in accordance with the Fund's policies on such consultations.

10. The government will take all necessary measures to ensure that the fifth program review is completed by May 2008 at the latest. This review will be based on the quantitative and structural performance criteria at end-December 2007.

11. Given the results obtained to date and the commitments undertaken in the Memorandum of Economic and Financial Policies, the government requests that the fifth disbursement under the arrangement, an amount equivalent to SDR 2.65 million, be made available upon completion of the fourth review. 
12. Finally, the government of Cameroon authorizes the IMF to make this letter and the attached MEFP available to the public.

Sincerely yours,

Inoni Ephraim

Prime Minister and

Head of Government

Enclosures: Memorandum of Economic and Financial Policies

Technical Memorandum of Understanding 


\section{REPUBLIC OF CAMEROON}

\section{Memorandum of Economic and Financial Policies}

Yaoundé, November 29, 2007

\section{INTRODUCTION}

1. In the first half of 2007 , the government pursued its efforts to improve budget management and transparency. The implementation of structural reforms was mixed, however: progress was made in strengthening budget management, but delays occurred in financial sector, civil service, and public enterprise reforms. This memorandum reviews the achievements during the January-June 2007 period of the three-year program supported by the IMF under the PRGF and describes the economic and financial objectives and policies for the July 2007 to June 2008 period.

\section{RECENT ECONOMIC DEVELOPMENTS AND RESULTS OF THE IMPLEMENTATION OF THE PRGF-SUPPORTED PROGRAM}

2. Nonoil GDP growth in 2006 was revised downward to 2.9 percent following, among other things, the disappointing performance of industrial export crops, agro-industry, and other manufacturing industries, which were adversely affected by the slowdown in the production of cotton and related products (oil, fabrics) due to declining yields. Growth in agro-industry was also hindered by the decline in sugar production. The external current account improved, with stronger imports being offset by oil and nonoil exports. Nonoil exports were partially driven by an accumulation of non-exported timber in 2005 .

3. Despite strong growth in net foreign assets in the first half of 2007, monetary growth was contained thanks to a reduction in government liabilities to the banking system. Private sector credit growth continued to slow, the repayment of government arrears enabling the private sector to reduce their outstanding credit to banks and self-finance their operations. Inflation continued its decline as a result of more moderate fuel price increases and reduced taxation of certain essential goods.

4. The overall fiscal surplus was higher than projected in the first half of 2007, despite a revenue shortfall, reflecting lower-than-projected spending. As a result, most quantitative targets for end-June 2007 were met. Nevertheless, shortfalls were recorded in nonoil revenues, because both taxes on international trade and nontax revenues fell short of expectations, due to reduced taxation on some imported goods and delayed payments of dividends. Investment execution was mixed: although domestically-financed investments were close to the budget target, foreign-financed and MDRI/HIPC investments were significantly lower than budgeted due to delays in project planning and preparation. 
5. Structural reform implementation in the period January-June 2007 was mixed:

- $\quad$ Public finance. The performance criterion for end-June on the interconnection between the IT systems of the General Directorates of the Budget and the Treasury was observed.

- $\quad$ Financial sector. Preparatory work to establish the financial subsidiary of CAMPOST (performance criterion) was not completed, as this process proved more complex than expected, given the legal status of CAMPOST and the nature of its activities. In order to complete this reform, the accounts for the 2004-2005 fiscal years were produced in October 2007, those for the 2006 fiscal year in November 2007; and the draft business plan for CAMPOST financial activities was prepared in November 2007.

- Civil service. The new payroll records have already been used to: (i) calculate the cost of salary adjustments; and (ii) assess the wage arrears stemming from past unpaid promotions. There was a delay in observance of the benchmark on the preparation of a preliminary diagnostic study of the civil service remuneration system (salaries and benefits). The benchmark related to the harmonization of civil service personnel records was observed at 26 ministries, but SIGIPES (Automated Integrated Management System) was not installed in 14 ministries due to the government's decision to change the technology to be used. Contracts for procuring the required equipment were awarded and deliveries are expected from December 2007. User training at the 24 SIGIPES sites will be completed in March 2008.

6. The government continued to implement transparency-enhancing measures, but delays have been experienced in meeting some of the anticorruption commitments:

- $\quad$ Publication. The quarterly budget execution reports, the quarterly operating reports of the national oil company (SNH), and the annual financial aggregates of the main public enterprises were published. Statistical data and debt analyses were published on the CAA (National Amortization Fund) website (www.caa.cm). Judicial decisions and administrative penalties against government employees as part of the anti-corruption campaign were also published on the Prime Minister's website (www.spm.gov.cm). The second report under the Extractive Industries Transparency Initiative (EITI) covering 2005 was also published on the government's website.

- $\quad$ Fight against corruption. The National Anti-Corruption Commission (CONAC), established in March 2006, began operations in March 2007 following the appointment of its chairman and members. It has already conducted its first investigations in Douala and Yaoundé. However, the Commission planned as part of the implementation of asset disclosure by senior government officials has not yet 
begun its activities, as the implementing regulations under the law have not yet been adopted.

\section{ECONOMIC AND FinanCIAL Policies FOR 2007 AND 2008}

\section{A. Macroeconomic Framework}

7. The economic outlook should improve in 2007 and 2008, partly due to the beneficial impact of external debt relief under the HIPC Initiative and the MDRI. Nonoil real GDP growth is projected to about 3.4 percent in 2007 and 4.5 percent in 2008, mainly as a result of the recovery in the agriculture and service sectors and increased public investment. The inflationary pressures evident in 2006, driven mainly by higher oil prices, should ease in 2007, but could re-emerge in 2008 if the prices of food imports remain high.

\section{B. Fiscal Reforms and Fiscal Policy}

8. Overall, the main fiscal objectives of the 2007 program remain unchanged. Projected oil revenues will exceed the programmed level by CFAF 60 billion. ${ }^{9}$ In light of the underperformance of nonoil revenues during the first half of the year, the government redoubled its efforts to improve revenue administration by enhancing ex post controls and stepping up the fight against smuggling. Projected nonoil revenues were nonetheless revised downward due to the lower-than-expected nonoil GDP.

9. The draft 2008 budget is part of a medium-term fiscal strategy of increasing priority spending to accelerate growth and poverty reduction while preserving macroeconomic stability. The government is aware that observance of the budget preparation timetable is essential for improving budget execution. Accordingly, it plans to present the draft 2008 budget to Parliament within the period prescribed in the Cameroonian Constitution (benchmark).

10. Total revenue (excluding grants) in 2008 should fall by 0.2 percent of GDP in comparison with 2007, on account of a decline in oil revenues ( 0.5 percent of GDP), which reflects an increase in production costs, which will be only partly offset by the improved mobilization of nonoil revenue. In order to improve the administration of the value-added tax (VAT), the government will continue to ensure that VAT credits are refunded within the time limits provided by law.

\footnotetext{
9 The program's approach of using conservative oil price projections is maintained; oil prices have been estimated at a constant prudence factor of US\$7 per barrel below the IMF's World Economic Outlook (WEO) projections (excluding the US\$3 per barrel discount on Cameroonian crude).
} 
11. The mobilization of nonoil revenue is a major challenge for Cameroon. To achieve its revenue targets, the government is committed to accelerating the implementation of several administrative measures: (i) streamlining of taxpayer identification, reforming the single taxpayer identification number (IDU), and safeguarding the single taxpayer file will be completed by end-December 2007 (benchmark); (ii) the implementation of a tax-related information management software (AREN) will also be completed by end-November 2007; and (iii) by end-December 2007, the number of taxpayers covered by tax centers in Yaoundé and Douala for medium-sized enterprises will grow by some 40 percent compared with the tax rolls as at January 1, 2007, and by 45 percent at end-June 2008; and (iv) the number of tax centers for small taxpayers will be reduced with the establishment of initial experimental pilot sites in Yaoundé and Douala by end-March 2008.

12. Should administrative measures prove insufficient to mobilize nonoil revenue, the government will take additional steps (including at the tax policy level) to achieve the program's revenue targets. The following tax measures could be considered: (i) reduction of the 30 percent wage allowance to 20 percent and limiting it to the first CFAF 5 million; (ii) limiting exemptions for interest income to one account per taxpayer; (iii) taxing all in-kind benefits at their market value or at the cost of the employer providing them; and (iv) suspending tax exemptions that breach CEMAC rules.

13. As part of the 2007 budget, the following tax measures aimed at stimulating investment and reducing the impact of price increases on consumer purchasing power were implemented: a reduction, for a maximum of three years, in the income tax of individuals and legal entities reinvesting in Cameroon; a reduction of the corporate tax rate to 30 percent over the first five years for companies that place at least 20 percent of their capital on the stock exchange and remain listed for at least five years; exemption of capital gains on stock market transactions for individuals and legal entities; exemption from registration fees of share certificates and transactions on the stock market; a reduction in the CET applicable to capital goods for the agriculture, livestock farming, fisheries, industry, tourism, handicrafts, and energy sectors from 10 to 5 percent; and the decategorization of some imported goods by reducing the CET from 20 and 10 to 5 percent. To preserve the tax base, the government will refrain from introducing new tax exemptions or incentives that would result in a revenue loss, that are not well-targeted, or that would introduce economic distortions until a diagnostic study is conducted on the budgetary impact of existing exemptions and the options for streamlining the current system.

14. Finally, in April 2007, the government created a commission to review domestic and foreign trade taxation, in an effort to improve the mobilization of nonoil revenue. This commission, comprised of government departments, economic operators, and civil society, will submit a summary report on its work and recommendations by end-December 2007. Based on that report, a medium-term taxation reform plan will be adopted during the first half of 2008. The objective of this plan is to improve the fairness and efficiency of the 
current tax system and mobilize nonoil revenue. The first round of reforms will be proposed in the draft 2009 budget.

15. To increase forestry revenue, the government is planning to reestablish the Program to Secure Forestry Revenue (PSRF) as the sole point of contact for the forestry sector for tax purposes. Protocols for collaboration will be defined between the PSRF and all other entities involved in monitoring the forestry sector, and will state clearly the data required from the entities, as well as the periodicity, deadlines, and modalities for transferring the data. In addition, the government intends to establish an online connection between the Ministry of Forests and Wildlife and the Ministry of Finance by end-June 2008. This is essential for restoring the capacity to monitor sectoral economic data and control the tax base.

16. In 2008, the government will concentrate its expenditures in the priority areas of the PRSP and accelerate public investment. Thus, capital expenditure will increase by 1 percentage point of GDP from its 2007 level, primarily due to an increase in domestically-financed investment. Public investment will be channeled mainly into infrastructure development, the agricultural, health and education sectors. Current expenditure will rise by 0.1 percentage point of GDP to accommodate the wage bill increase and expenditures on goods and services. Subsidies and transfers as a percentage of GDP will fall, partly reflecting the continued efforts to restructure public enterprises.

17. The authorities plan to pursue a prudent hiring policy and gradually increase salaries within a stable and sustainable medium-term macroeconomic framework to enhance the efficiency of the civil service, combat corruption, and improve the economic welfare of civil servants. To this end, the government (i) regularized the status of some 13,000 contractual employees in 2007 by incorporating them into the civil service; (ii) began to adjust salaries and reduce the wage arrears stemming from the past unpaid promotions; and (iii) recruited new staff in priority sectors. The government also plans to correct wage differences based on a more in-depth diagnostic study of the civil service remuneration system. This study will include the following components: (i) the identification of resources to ensure that adjusted salaries are paid over time and that improved working conditions are implemented; and (ii) an assessment of the advantages and other in-kind benefits given to civil servants and the possibility of incorporating them into wages. Furthermore, as indicated below, the government plans to implement measures to continue containing the wage bill and staffing levels.

18. Aware of the key importance of an organic budget law for fiscal reforms, the government will present the draft constitutional by-law regarding budget procedures at the ordinary session of Parliament by end-2007.

19. The government intends to pursue efforts to reinforce the budget information system. In this regard, it will hold discussions with its technical and financial partners on the production, over the medium term, of the government financial operations table (TOFE) on a 
commitment basis. To accomplish this objective, it will conduct a diagnostic study by end-March 2008 on the measures and the critical path for preparing the TOFE on a payment order basis for all expenditures, with a detailed costing of required investments, particularly for equipping the various offices throughout the country. On this basis, the TOFE for the 2007 budget execution will be produced by end-May 2008. In the meantime, the government will continue its efforts to contain the outstanding payment orders. Furthermore, the government will formulate a plan by end-December 2007 to intensify its public expenditure management initiatives as part of the platform developed with its technical and financial partners.

20. To improve the execution of poverty reduction expenditure, the government will take steps to ease the constraints on HIPC and C2D financing by involving donors in discussions in the budget consultation process. The government will also take measures to accelerate the execution of capital expenditure while also implementing safeguards to ensure the quality of each project, including by prioritizing projects based on cost-benefit analyses. To this end, it created the Ministry of Economy, Planning, and Regional Development, which will be responsible, in the area of public investment, for designing the public investment program; ensuring the monitoring and control of investment programs and projects in collaboration with the sectoral ministries and the Ministry of Finance; strengthening the government's capacity for planning, preparing, evaluating, and executing projects; ensuring the availability of counterpart funds; and preparing a roadmap for the multiyear execution of the investment budget. In addition, the government will continue to strengthen the existing overall and sectoral medium-term expenditure frameworks (MTEF) and their use in the budget preparation process.

21. Starting with the 2008 budget, expenditure items that have been committed, but for which payment has not been authorized by the end of a fiscal year, will be entered as priority items in the budget for the following year. In addition, the government has established a legal framework for the general rules governing public-private partnership (PPP) contracts to stimulate investment in large-scale projects. The government plans to resort to this type of partnership provided that: (i) the project has been subjected to an economic analysis determining that it will generate net gains for the economy and showing that the project is the lowest-cost option in the sector; (ii) it is financially more profitable than a traditional public investment; and (iii) budgetary risks have been assessed.

22. The government intends to pursue its public procurement reforms by periodically assessing the public procurement system and systematically publishing the penalties imposed on those who fail to comply with these regulations. To this end, the government implemented the standard bid documents and procedural manuals on August 29, 2007. In addition, by endDecember 2007 the government plans to (i) publish the audit report on public procurement activities in 2005; (ii) adopt the implementing regulations on amicable settlement under the Public Procurement Code; (iii) evaluate public procurement reforms to enhance transparency 
and effectiveness (thereby reducing costs and delays) in the public procurement system; and (iv) annually assess the reliability and performance of the national public procurement system, using a set of performance indicators defined in collaboration with the World Bank.

23. The government is committed to continue using any windfall in oil revenue exclusively for one-off purposes, particularly to: (i) accelerate payments on domestic debt and arrears; (ii) buy back debt held by external commercial creditors who did not take part in the commercial debt repurchase initiative (London Club); and (iii) finance investment projects in the sectors defined in the PRSP, including the counterpart funds for jointly-financed projects such as infrastructure development (notably roads, energy) and investment in major sectoral programs (education, health, and rural and urban development).

\section{Civil Service}

24. The government will continue its ongoing civil service reforms to establish a solid basis for determining staffing levels and the payroll, secure and harmonize the related records, and increase the efficiency of the civil service. Following the clean-up of the payroll file, measures were taken to maintain the accuracy of these records in order to further contain the wage bill and staffing levels. Payroll records will be harmonized throughout the civil service by end-2007. An integrated management system for the civil service and the payroll (SIGIPES) will be set up at 24 ministries, covering 80 percent of government workers, by end-June 2008 (benchmark). The system will be expanded to include the rest of the civil service by end-2008. The government is also planning to replace the current IT system used for the payroll with a more efficient one, particularly in terms of security and access rights. In this regard, it will audit the current system by December 2008 with the assistance of the World Bank, and work with the Bank to devise a strategy for civil service reform in the context of the next Country Assistance Strategy.

\section{Fuel Pricing Policy}

25. The policy of adjusting retail fuel prices, which began in 2005 as part of Cameroon's financial program, will be pursued. However, the expected increase in crude prices will be fully reflected in an increase in fuel prices so that budgetary transfers to SONARA are kept within the planned envelope, which will be capped at CFAF 25 billion in 2008. The government will gradually eliminate fuel price subsidies. It will use the resulting budget savings to improve the social safety net. In this regard, a study will be conducted to determine the modalities and mechanisms for implementing this process.

26. The government is committed to adopting a system for full pass-through of fuel prices. In this regard, it will adopt by end-December 2007 a formula for adjusting SONARA ex-refinery prices (reflecting international prices and allowing an automatic adjustment) and a simplified price structure (reducing or eliminating the cross-subsidies and tax distortions of the current pricing regime) (performance criterion) and start implementation in January 2008. 
To this end, a study will be conducted in December 2007 to assess the possible fiscal implications of this reform.

27. The government also intends to pursue the implementation of measures to bolster the financial position of SONARA and reduce budget transfers. To this end, it is conducting a feasibility study that will determine the cost of the investments required to improve the refining system, their economic viability, and their financing modalities. In particular, the government will make no further investments unless they are proven to be economically viable and they can be financed within the framework of a sustainable fiscal policy.

\section{E. External Debt Management and Trade Liberalization}

28. The government will pursue a prudent debt policy and ensure that its debt is managed in a sustainable manner. With this objective in mind, it will finalize the preparation of a new comprehensive public debt management strategy in accordance with the regulation of the Council of Ministers of the Central African Economic and Monetary Community (CEMAC) approved in March 2007. This strategy will be adopted by November 30, 2007 at the latest by the Public Debt Coordination and Monitoring Unit, and will be developed and implemented on an annual basis and be attached to the Budget Law. The strategy will be consistent with macroeconomic framework, the medium-term fiscal objectives, and in particular, will include the following:

- A maximum ceiling on annual indebtedness;

- The contracting of loans on concessional terms;

- A detailed study of projects requiring loan financing; and

- A debt sustainability analysis, conducted at least once a year and before signing any loans amounting to more than 0.5 percent of GDP.

29. In addition to the implementation of the Public Debt Coordination and Monitoring Unit, the government plans to take the following actions before end-2007: (i) clarify the legal and institutional framework of debt policy and management (define the respective roles of the concerned administrations, notably the Treasury, Budget, Economic Affairs, the CAA, and the CTS); (ii) set an indebtedness ceiling and define priorities for debt management. Finally, the government will request technical assistance from the International Monetary Fund in the area of debt management.

30. The government also plans to finalize the signing of agreements with bilateral creditors. It will continue to negotiate in good faith with its private creditors to clear its arrears, without overlooking the principle of comparable treatment. 
31. As part of the CEMAC institutional reform program and the consolidation of subregional integration, Cameroon will propose that CEMAC member countries: (i) assess and reduce obstacles to the development of sub-regional trade, including the issue of the free circulation of goods in the CEMAC zone; (ii) pursue efforts to manage and reduce exemptions; and (iii) address this issue on the agenda for the next meeting. In addition, after having consulted with the community organizations that will meet in N'Djamena in June 2008, Cameroon will continue to support CEMAC reforms by gradually reducing the Common External Tariff (CET) from 30 to 20 percent. Furthermore, after eliminating minimum values on fish and salt, Cameroon plans to also eliminate the minimum administrative values for all imported products by end-June 2008. To facilitate foreign trade operations and in light of the implementation of the electronic one-stop shop the government will complete its project to link participants involved in port transactions by end-June 2008 . Finally, Cameroon will work towards ensuring that Central Africa signs an economic partnership agreement (EPA) with the European Union by end-December 2007; and that the EPA is balanced, promotes development, and takes account of both losses in tax revenue that must be offset as well as the need to build capacities and upgrade businesses.

\section{F. Financial Sector}

32. Based on the joint IMF-World Bank mission's recommendations in the context of the Financial Sector Assessment Program (FSAP), the government will prepare an action plan for strengthening financial intermediation by end-December 2007.

33. In the interim, the government is committed, at the national level, to supporting initiatives to facilitate credit access by reducing the constraints in the business environment, notably through: (i) a significant improvement in financial reporting; (ii) simplification of the procedures for calling in collateral; and (iii) the establishment of a commercial court. Thus, the government will work with the Bank of Central African States (BEAC) to expedite the process of updating the list of clients in default of liquidated or restructured banks included in the central credit register. In an effort to better protect depositors, the list of accredited microfinance institutions (MFIs) will be regularly published beginning in January 2008. In addition, the government will propose that the Central African Banking Commission (COBAC) issue a regulation requiring that the subregion's lending establishments regularly publish information on the financial status of banks to ensure the transparency of lending operations. At the regional level, the government is also committed to supporting the BEAC in finalizing the establishment of the central credit register (computerization, payment problems bureau, financial analysis center).

34. To provide an alternative source of financing to meet the needs of the economy, the government will pursue its efforts to develop the securities market by allowing secondary market transactions on zero-coupon treasury bonds in the financial market by end-December 2007 (benchmark). In 2008, it also plans to limit the use of all new statutory advances and 
issue publicly-traded government securities. Transactions in government securities will take place under the supervision of the Financial Markets Commission (CMF).

35. Based on the results of the business plan for CAMPOST financial activities, the government is planning to hold detailed discussions to determine the most appropriate method for CAMPOST to offer financial services throughout the country. In order to ensure the rebuilding of CAMPOST's assets, the authorities will continue to ensure the financial supervision of CAMPOST by the staff of the Ministry of Finance responsible for monitoring nonbank financial institutions, who will produce a quarterly supervision report. The next report, which will focus on operations during the final quarter of 2007, will be available by end-June 2008. Furthermore, transfers to CAMPOST will be limited to the minimum amount needed to meet the required annual working capital, estimated at CFAF 22.5 billion. In addition, the social organs of CAMPOST will be notified of the requirement to report the financial activity accounts separately from those of the postal activities.

\section{G. Transparency, Good Governance, and the Business Climate}

36. The government is resolute in its decision to enhance good governance and combat corruption in an effort to improve the business environment and the quality of public expenditure. To that end, it will keep publishing on the Internet the summary of the reports of the local committees monitoring the physical and financial implementation of the investment projects in the central government budget, as well as the judicial decisions and the administrative sanctions against civil servants. The government will also ensure that the Commission planned to implement the asset disclosure process for senior government officials is operational by end-2007. In addition, following a joint OECD-DAC donors mission in 2006, the joint CHOC program (Change Habits-Out with Corruption) of the government and donors was adopted in February 2007. This will be used as a basis for the government's preparation of an anti-corruption strategy by end-December 2007. An action plan to assess corruption among staff at the Ministry of Finance will be prepared by March 2008, and completed by end-December 2008 .

37. The government will take steps to improve the business climate. By March 2008, it will prepare a private-sector development strategy in partnership with the private sector and in collaboration with its development partners. Also, by end-December 2007, the government will implement a one-stop shop for business creation to reduce the time and expense involved in setting up a business.

38. The government will continue to pursue public enterprise reforms, though progress has been slow, given the complexity of the problems facing these enterprises and the underlying social issues involved. In collaboration with the World Bank, the government will continue implementing its public enterprise privatization and restructuring programs. Regarding CAMTEL, the government prepared financial information for 2006 and incorporated investors' suggestions for improving the transaction structure initially proposed. 
The objective is to complete the selection of a provisional successful bidder by end-December 2007. For the SNEC, the government selected a provisional successful bidder for the management contract (contrat d'affermage) in September 2007. Negotiations with the provisional successful bidder and the contract signing will be completed by end-December 2007. In the airline sector, the government remains committed to eliminating government subsidies to airline companies, including CAMAIR, and improving service quality in the air transport sector. To this end, the government is splitting up and liquidating CAMAIR and will limit transfers and subsidies to the amounts agreed with the IMF in the 2007 budget framework. It will also prepare a calendar for the gradual elimination of subsidies by June 2008. The government will complete the process of selecting a financial advisor for the privatization of CAMAIRCO by November 2007 and will issue a tender for the selection of a private strategic partner by April 2008.

\section{Monitoring Program Implementation}

39. Program monitoring from July 2007 to end-June 2008 will be based on the performance criteria and quarterly indicative targets and structural benchmarks indicated in Tables 3 and 4 . The government will report the data necessary for program monitoring to the IMF, in accordance with the Technical Memorandum of Understanding. 


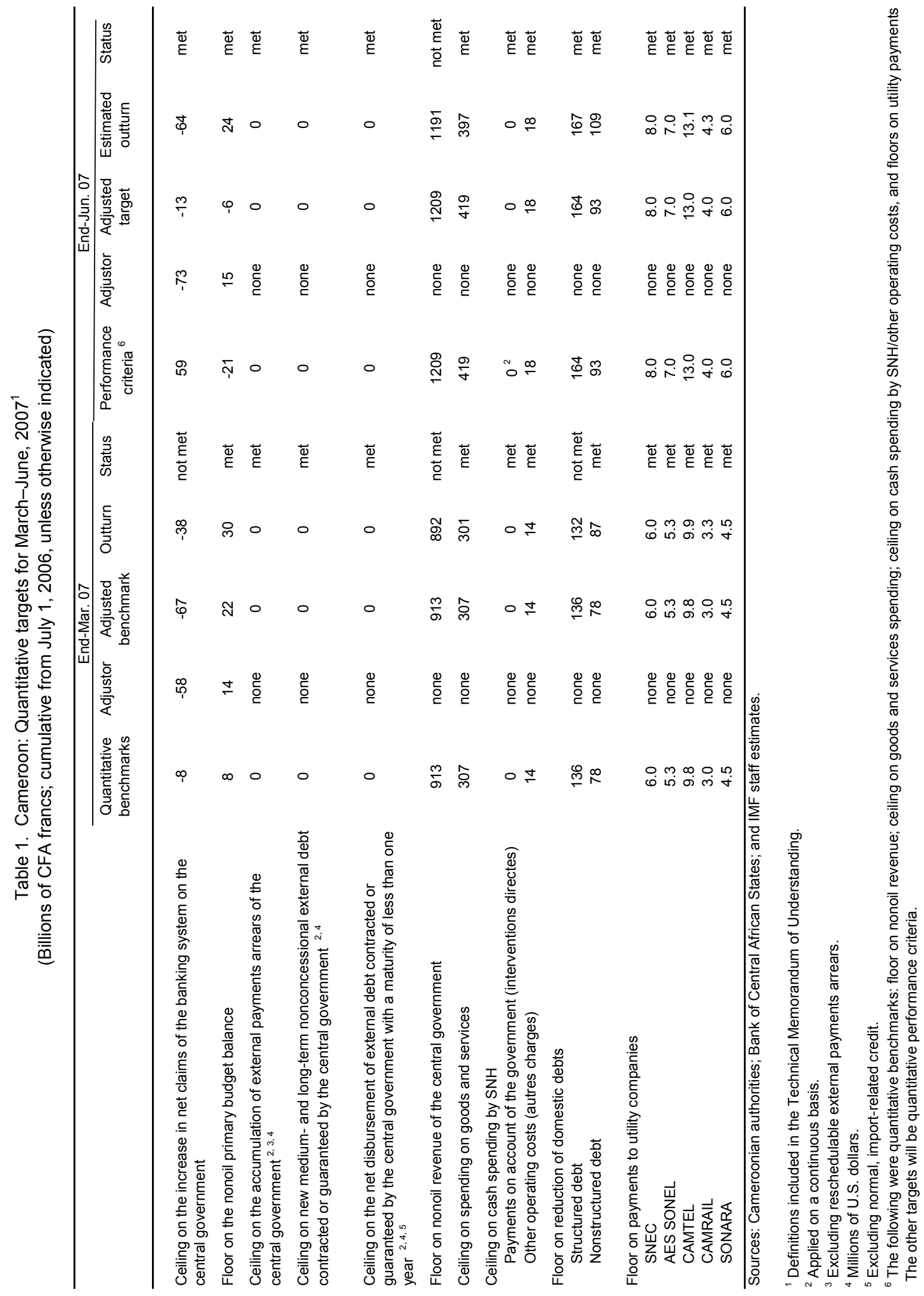


Table 2. Cameroon: Structural Performance Criteria and Benchmarks for the Period July 2006 to June 2007

Measure

\section{Government Finance}

Submission to Parliament of the 2007 budget law in accordance with the program and adoption by end-2006 (performance criterion).

Implementation of the Customs Management System in the customs sectors of the Littoral province (performance criterion).

Consolidation of the online connection between the IT systems of the General Directorates of Budget and the Treasury and production of monthly summary reports on budget execution - from commitment through paymenton a functional basis for the January-April 2007 period (performance criterion).

Diagnostic study of the budget and treasury nomenclature to assess its consistency with GFS standards and preparation of an analytical report.

Preparation of actions to be taken during the transitional period of the new organic law on government finance and a timetable for their implementation.

Preparation of consistent monthly budget execution tables on cash and commitment bases and a monthly expenditure table, broken down by economic function, to track spending for priority sectors.

Adjustment of the retail prices of petroleum products and payment of budgetary transfers to SONARA as agreed with Fund staff.

\section{Civil Service}

Completion of the census of civil servants conducted by the Ministry of Economy and Finance (MINEFI) and clean-up of the payroll records based on the data compiled.
Date

Status

December 31, 2006 Completed

December 31, 2006 Completed

June 30, 2007

Completed

March 31, 2007

Completed

April 30, 2007

Completed

Ongoing

Completed

Ongoing

Completed

December 31, 2006 Completed 
Preparation of a diagnostic study on the civil service remuneration system (salaries and benefits).

Establishment of harmonized civil service personnel records based on the reconciliation of the censuses of the Ministry of Finance and the Ministry of the Civil Service at 14 ministries, and installation of the personnel management system in these ministries.

\section{Transparency and Governance}

Publication of the report of the Extractive Industries Transparency Initiative (EITI) administrator on oil revenues for 2001 to 2004 on the government website (www.spm.gov.cm)

Publication of the report of the EITI conciliator on oil revenue for 2005 on the website www.spm.gov.cm.

Publication of the quarterly report on execution of the government budget.

Publication on the website www.spm.gov.cm as part of the anti-corruption campaign of: (i) judicial decisions; and (ii) administrative sanctions against civil servants.

\section{Financial Sector}

Completion by the government of the preparatory work for the establishment of a financial subsidiary for CAMPOST (performance criterion).

\section{Public Enterprise Reform}

Launching the invitation for bids for the privatization of CAMTEL (performance criterion).

Launching the invitation for bids for the management contract of the public-private partnership for SNEC.
March 31, 2007

Not completed

June 30, 2007

Not completed

December 31, 2006

Completed

March 31, 2007

Completed

Two months after Completed the end of the quarter

Ongoing

Completed

June 30, 2007

Not

completed

March 31, 2007

Completed

March 31, 2007

Completed 
Table 3. Cameroon: Quantitative targets for Sept. 2007-June, $2008^{1}$

(Billions of CFA francs; cumulative from January 1 , unless otherwise indicated)

\begin{tabular}{|c|c|c|c|c|}
\hline & End-Sep. 07 & End-Dec. 07 & End-Mar. 08 & End-Jun. 08 \\
\hline & $\begin{array}{l}\text { Quantitative } \\
\text { benchmarks }\end{array}$ & $\begin{array}{l}\text { Performance } \\
\text { criteria } 6 /\end{array}$ & $\begin{array}{l}\text { Quantitative } \\
\text { benchmarks }\end{array}$ & $\begin{array}{l}\text { Performance } \\
\text { criteria } 6 /\end{array}$ \\
\hline $\begin{array}{l}\text { Ceiling on the increase in net claims of the banking system on the } \\
\text { central government }\end{array}$ & -16 & -78 & -38 & -81 \\
\hline Floor on the nonoil primary budget balance & -72 & -46 & 24 & -2 \\
\hline $\begin{array}{l}\text { Ceiling on the accumulation of external payments arrears of the } \\
\text { central government } 2,3,4\end{array}$ & 0 & 0 & 0 & 0 \\
\hline $\begin{array}{l}\text { Ceiling on new medium- and long-term nonconcessional external debt } \\
\text { contracted or guaranteed by the central government } 2,4\end{array}$ & 0 & 0 & 0 & 0 \\
\hline $\begin{array}{l}\text { Ceiling on the net disbursement of external debt contracted or } \\
\text { guaranteed by the central government with a maturity of less than one } \\
\text { year } 2,4,5\end{array}$ & 0 & 0 & 0 & 0 \\
\hline Floor on nonoil revenue of the central government & 908 & 1250 & 356 & 678 \\
\hline Ceiling on spending on goods and services & 343 & 418 & 111 & 228 \\
\hline \multicolumn{5}{|l|}{ Ceiling on cash spending by SNH } \\
\hline $\begin{array}{l}\text { Payments on account of the government (interventions directes) })^{2} \\
\text { Other operating costs (autres charges) }\end{array}$ & $\begin{array}{c}0 \\
14\end{array}$ & $\begin{array}{c}0 \\
18\end{array}$ & $\begin{array}{c}0 \\
4.5\end{array}$ & $\begin{array}{c}0 \\
9.0\end{array}$ \\
\hline \multicolumn{5}{|l|}{ Floor on reduction of domestic debts } \\
\hline Structured debt & 99 & 143 & 27 & 54 \\
\hline Nonstructured debt & 54 & 71 & 9 & 18 \\
\hline \multicolumn{5}{|l|}{ Floor on payments to utility companies } \\
\hline SNEC & 6.0 & 8.0 & 2.0 & 4.0 \\
\hline AES SONEL & 5.3 & 7.0 & 1.8 & 3.5 \\
\hline CAMTEL & 9.9 & 13.1 & 3.3 & 6.5 \\
\hline CAMRAIL & 3.0 & 4.0 & 1.0 & 2.0 \\
\hline SONARA & 4.5 & 6.0 & 1.5 & 3.0 \\
\hline
\end{tabular}

Sources: Cameroonian authorities; Bank of Central African States; and IMF staff estimates.

${ }^{1}$ Definitions included in the Technical Memorandum of Understanding.

${ }^{2}$ Applied on a continuous basis.

${ }^{3}$ Excluding reschedulable external payments arrears.

${ }^{4}$ Millions of U.S. dollars.

${ }^{5}$ Excluding normal, import-related credit.

${ }^{6}$ The following will be quantitative benchmarks: floor on non-oil revenue; ceiling on goods and services spending; ceiling on cash spending by SNH/other operating costs; and floors on utility payments. The other targets

will be quantitative performance criteria. 
Table 4. Cameroon: Structural Performance Criteria and Benchmarks from July 2007 to June 2008

\section{Public Finance and Civil Service}

Deadline

Completion of the work related to streamlining taxpayer identification,

December 31, 2007

upgrading the single identification software, and safeguarding the single taxpayer file.

Adoption by the government of a formula for the revision of SONARA December 31, 2007 exit refinery prices and a simplified structure of petroleum product prices to facilitate automatic adjustment (performance criterion).

Submission to Parliament the 2008 Budget Law in accordance with the December 31, 2007 program.

Completion of the work to connect the information system of the

March 31, 2008

General Directorate of Taxes (MESURE) to that of the General

Directorate of Customs (ASYCUDA).

Installation of the Automated Integrated Management System

June 30, 2008

(SIGIPES) covering civil servants and the payroll in 24 ministries.

Adoption of a medium-term tax reform plan building upon the

June 30, 2008

recommendations of the Review Commission of Domestic and Foreign

Trade Taxation.

Adjustment of retail prices of petroleum product and payment of budgetary transfers to SONARA as agreed with Fund staff.

\section{Financial Sector, Trade, and the Business Climate}

Transfer of secondary-market transactions on zero-coupon treasury

December 31, 2007

bonds to the financial market.

Presentation to Parliament of the Law on Electronic Communications June 30, 2008 and Electronic Payments of Banks.

Complete and implement the electronic one-stop shop to facilitate foreign trade.

Financial supervision of CAMPOST by the unit of the Ministry of

Ongoing

Finance in charge of the monitoring of nonbank financial institutions, and production by this unit of the quarterly supervisory report covering the operations of the final quarter of 2007 (performance criterion).

June 30,2008

June 30, 2008 
Table 5. Cameroon: Central Government Operations, 2007

(Billions of CFA francs, unless otherwise indicated)

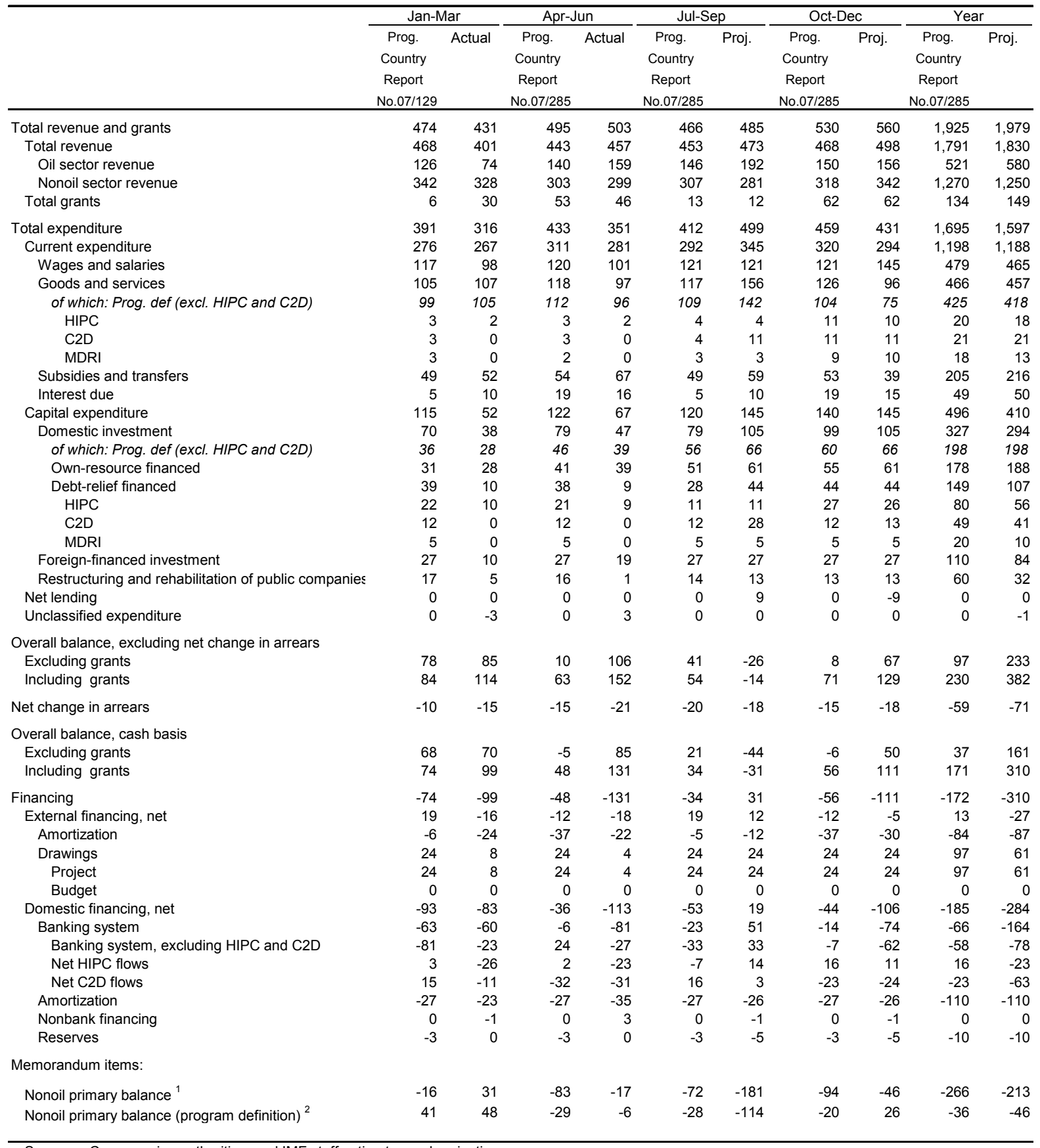

Sources: Cameroonian authorities; and IMF staff estimates and projections.

${ }^{1}$ Excludes grants, interest, and foreign-financed capital expenditures.

${ }^{2}$ Excludes restructuring, HIPC- and C2D-financed expenditures, in addition to grants, interest, and foreign-financed capital expenditures. 
Table 6. Cameroon: Central Government Operations, 2008

(Billions of CFA francs, unless otherwise indicated)

\begin{tabular}{|c|c|c|c|c|c|}
\hline & Jan-Mar & Apr-Jun & Jul-Sep & Oct-Dec & Year \\
\hline & Proj. & Proj. & Proj. & Proj. & Proj. \\
\hline Total revenue and grants & 471 & 506 & 470 & 566 & 2,012 \\
\hline Total revenue & 460 & 473 & 459 & 533 & 1,924 \\
\hline Oil sector revenue & 103 & 151 & 140 & 174 & 568 \\
\hline Nonoil sector revenue & 356 & 322 & 319 & 359 & 1,356 \\
\hline Total grants & 11 & 33 & 11 & 33 & 89 \\
\hline Total expenditure & 417 & 449 & 461 & 483 & 1,811 \\
\hline Current expenditure & 296 & 318 & 319 & 341 & 1,273 \\
\hline Wages and salaries & 115 & 120 & 130 & 147 & 510 \\
\hline Goods and services & 119 & 125 & 125 & 131 & 501 \\
\hline of which: debt-relief financed & 13 & 13 & 13 & 13 & 51 \\
\hline HIPC & 2 & 2 & 2 & 2 & 9 \\
\hline C2D & 6 & 6 & 6 & 6 & 24 \\
\hline MDRI & 5 & 5 & 5 & 5 & 18 \\
\hline Subsidies and transfers & 52 & 58 & 54 & 52 & 215 \\
\hline Interest due & 10 & 15 & 10 & 11 & 47 \\
\hline Capital expenditure & 122 & 132 & 143 & 142 & 538 \\
\hline Domestic investment & 81 & 86 & 97 & 96 & 359 \\
\hline Own-resource financed & 51 & 50 & 60 & 56 & 216 \\
\hline Debt-relief financed & 30 & 36 & 37 & 40 & 143 \\
\hline HIPC & 12 & 18 & 18 & 21 & 69 \\
\hline $\mathrm{C} 2 \mathrm{D}$ & 14 & 14 & 14 & 14 & 56 \\
\hline MDRI & 4 & 4 & 5 & 5 & 18 \\
\hline Foreign-financed investment & 30 & 35 & 35 & 35 & 135 \\
\hline Restructuring and rehabilitation of public companies & 11 & 11 & 11 & 11 & 44 \\
\hline Unclassified expenditure & 0 & 0 & 0 & 0 & 0 \\
\hline \multicolumn{6}{|l|}{ Overall balance, excluding net change in arrears } \\
\hline Excluding grants & 42 & 23 & -3 & 50 & 113 \\
\hline Including grants & 54 & 57 & 8 & 83 & 202 \\
\hline Net change in arrears & -9 & -9 & -9 & -9 & -35 \\
\hline \multicolumn{6}{|l|}{ Overall balance, cash basis } \\
\hline Excluding grants & 34 & 15 & -11 & 41 & 78 \\
\hline Including grants & 45 & 48 & -1 & 74 & 167 \\
\hline Financing & -45 & -48 & 1 & -74 & -167 \\
\hline External financing, net & 30 & 10 & 31 & 3 & 74 \\
\hline Amortization & -8 & -22 & -12 & -30 & -71 \\
\hline Drawings & 38 & 32 & 43 & 32 & 146 \\
\hline Project & 27 & 32 & 32 & 32 & 125 \\
\hline Budget & 11 & 0 & 11 & 0 & 21 \\
\hline Domestic financing, net & -75 & -59 & -31 & -77 & -241 \\
\hline Banking system & -50 & -34 & -6 & -52 & -142 \\
\hline Banking system, excluding HIPC and C2D & -38 & -43 & 8 & -61 & -134 \\
\hline Net HIPC flows & 1 & 1 & 1 & 1 & 2 \\
\hline Net C2D flows & -13 & 9 & -14 & 9 & -10 \\
\hline Amortization & -20 & -20 & -20 & -20 & -79 \\
\hline Nonbank financing & 0 & 0 & 0 & 0 & 0 \\
\hline Reserves & -5 & -5 & -5 & -5 & -20 \\
\hline Remaining financing needs & 0 & 0 & 0 & 0 & 0 \\
\hline \multicolumn{6}{|l|}{ Memorandum items: } \\
\hline Nonoil primary balance ${ }^{1}$ & -21 & -77 & -97 & -77 & -273 \\
\hline Nonoil primary balance (program definition) ${ }^{2}$ & 24 & -26 & -46 & -23 & -71 \\
\hline
\end{tabular}




\section{Technical Memorandum of Understanding on the Definitions of the Performance Criteria and Benchmarks of the PRGF-supported Program for July 2007-June 2008 and the Modalities of Their Adjustment}

\section{A. Introduction}

1. This memorandum sets out the understandings between the Cameroonian authorities and the International Monetary Fund (IMF) regarding the definitions of the performance criteria and benchmarks of the program and the contingency mechanisms related thereto. It also specifies the program's exchange rates and the data to be reported to the IMF by the authorities.

\section{B. Definitions}

\section{Government}

2. Government is defined as central government unless otherwise noted.

\section{External debt}

3. External debt shall have the meaning set out in point 9 of the Guidelines on Performance Criteria with Respect to External Debt in Fund Arrangements (IMF Executive Board Decision No. 12274-00/85, dated August 24, 2000). External debt is defined on the basis of residency.

\section{Accumulation of external arrears}

4. External arrears are considered to be the external nonreschedulable arrears of the government, including public enterprises whose debt is guaranteed by the government. External nonreschedulable arrears includes the servicing of debt which is due and not paid to all multilateral creditors and to bilateral official and commercial creditors with whom a debt rescheduling or restructuring agreement has been concluded. The nonpayment of debt service to bilateral official and commercial creditors with whom a rescheduling or restructuring agreement has not yet been signed is not considered to be an arrear for the purposes of the program, provided that Cameroon is engaged in best efforts to negotiate a rescheduling or restructuring agreement with bilateral official and commercial creditors.

\section{Concessionality of external debt}

5. Medium- and long-term debt is considered to be debt with an initial maturity of one year or more. Debt with a maturity of one year or more is considered to be concessional if it includes a grant element equivalent to 35 percent or more, calculated on the basis of the commercial interest reference rate (CIRR) published by the OECD and following the 
methodology set out in the IMF staff paper entitled "Limits on External Debt or Borrowing in Fund Arrangement - Proposed Change in Implementation of the Revised Guidelines" (Country Report No. 07/285), approved by the IMF Executive Board on April 15, 1996. Thus, for debt maturing in 15 years or more, the OECD 10-year CIRR is used as the discount rate to assess concessionality. The following margins are added to the two CIRRs for the various repayment periods: 1 percent between 15 and 19 years; 1.15 percent between 20 and 29 years; and 1.25 percent when the repayment period is spread over 30 years or more. Debt rescheduling and restructuring as well as the use of IMF resources are not part of the performance criteria for the issuance or guarantee of nonconcessional debt.

\section{Debt relief}

6. For the purpose of the program, the only form of debt relief that will be subject to the contingency mechanism described below is the debt relief that leads to an effective reduction in programmed debt service. This includes, in particular, any relief in the form of rescheduling, forgiveness, restructuring, or a grant under the Heavily Indebted Poor Countries (HIPC) Debt Initiative, the Multilateral Debt Relief Initiative (MDRI), and bilateral initiatives (e.g., C2D_Debt Reduction and Development Contract). Programmed debt relief on debt that has been in drawn-out rescheduling/restructuring negotiations with non-Paris Club creditors, including commercial creditors, is excluded from the contingency mechanism as it does not lead to an effective reduction in programmed debt service.

\section{Domestic debt}

\section{Structured debt}

7. Structured debt is defined as debt that has been subject to a formal agreement (convention) or securitization (titrisation). For the purposes of the PRGF program, structured debt is limited to the stock of structured debt at end-December 2004 that was included in the audit completed in October 2005 and that is specified in the multiyear settlement plan for public domestic debt as recorded by the National Amortization Fund (CAA). The stock of this debt (excluding the BEAC's advances) at end-December 2004 amounted to CFAF 956 billion.

\section{Nonstructured debt}

8. Nonstructured debt is defined as debt not subject to a formal agreement (convention) or securitization (titrisation). For the purposes of the PRGF program, nonstructured debt is limited to the stock of nonstructured debt at end-December 2004 that was included in the audit completed in October 2005 and that is specified in the multiyear settlement plan for public domestic debt as recorded by the National Amortization Fund. The stock of this debt at end-December 2004 amounted to CFAF 496 billion. 


\section{Domestic debt repayments}

9. For assessing the observance of the quantitative performance criteria on the reduction of domestic debt, only those repayments of domestic debt are counted that are made to repay the structured and nonstructured domestic debt defined above. These repayments are recorded "below the line" in the Fund's "Central Government Operations" table. In the case of structured debt, they are (i) the payments on account of the securitized debt to the BEAC and commercial banks, which are entered in the line "Domestic financing, net - Banking System - Banking system excl. HIPC and C2D"; and (ii) other repayments of principal, which are recorded in the line "Domestic financing, net - Amortization". In the case of nonstructured debt, they are the repayments of principal, which are recorded in the line "Net change in arrears - Domestic".

\section{Government financial operations table (TOFE)}

10. The Treasury balance (Balance des comptes $d u$ Trésor) shows government revenue and expenditure posted in Class 6 accounts (current expenditure), Class 7 accounts (current revenue), and Class 2 accounts (investment operations). Debt-related operations are recorded in Class 1 accounts (debt operations) and partly in Class 5 (financial operations). The financial operations data must be consistent with the data in the treasury account at the BEAC. Data on provisional revenue and expenditure operations and deposits of the correspondents of the treasury are recorded in Class 4 accounts of the government's chart of accounts (plan comptable). Government operations that are not carried out through the Treasury need to be added to the data on operations that are carried out through the Treasury. Revenue and expenditure operations are recorded on a cash basis.

\section{Nonoil revenue}

11. Nonoil revenue comprises all government (tax and non-tax) revenue, excluding revenue from oil companies (i.e. companies engaged in crude oil extraction in Cameroon) and oil royalties (redevance pétrolière). VAT is recorded net of VAT refunds. The pipeline fee paid by the Cameroon Oil Transportation Company (CTOCO) is recorded as part of nontax revenue.

\section{Privatization proceeds}

12. For the purposes of the program, privatization proceeds will be understood to mean all funds received by the government from the sale or concessioning of the operation of a public company or organization or publicly owned facility to one or more private company(ies) (including companies that are fully controlled by foreign government(s), private organization(s), or individual(s)). Privatization proceeds also include all funds received from the sale of shares owned by the government in private companies or public 
enterprises. All privatization proceeds should be recorded on a gross basis; if any costs are incurred in connection with the sale or concessioning, these must be recorded separately as expenditure.

\section{Goods and services}

13. All budgetary expenditures on account of the purchase of goods and services are recorded in the accounts 4000060, 4000090, 4011, 4010060, 48131, 4810 and 40001205 of the Treasury balance account and shown accordingly in the TABORD. HIPC and C2D spending is excluded.

\section{Nonoil primary budget balance}

14. The nonoil primary budget balance (on a cash basis) is calculated as government nonoil revenue, excluding external grants, less all expenditure other than interest payments, foreign-financed investment expenditure, HIPC-financed expenditure, expenditure financed by the Debt Reduction and Development Contract (C2D) and restructuring expenditure.

\section{Net bank credit to the government}

15. Net claims on the government by the banking system comprise the stock of all outstanding claims on the government by the banking system (loans, advances, and any other government debt instruments, such as long-term government securities), less all deposits held by the Treasury with the banking system, excluding the HIPC account, the account for the $\mathrm{C} 2 \mathrm{D}$, and the two accounts held by the CAA in a commercial bank to pay the government's domestic and external debt obligations.

\section{Payments to utility companies}

16. The floor relating to "payment to utility companies" will be considered observed if payments to the utility companies (water, electricity, fixed-line telephones, railway and refinery companies) are made in quarterly amounts, as indicated in Table 3 of the MEFP. These payments are to exclude fiscal compensation, and they are assessed on the basis of cash disbursements. They are to be registered as current expenditures in the TOFE.

\section{Public enterprise restructuring expenditure}

17. Restructuring expenditures are defined as those expenditures that are made in the context of implementing a privatization strategy (CAMAIR, CAMTEL, CDC), a publicprivate partnership (SNEC) or a restructuring plan (CAMPOST, SONARA). The classification of an expenditure as "restructuring expenditure" should be made after consultation with the IMF. 


\section{Spending advances by SNH (interventions directes)}

18. Spending advances (interventions directes) by SNH (Société Nationale des Hydrocarbures) are defined as advance payments by SNH on behalf of the government. They are deducted from the monthly cash revenue transferred by the SNH to the government. There will be no interventions directes in 2006 or thereafter.

\section{Quasi-fiscal spending by SNH (autres charges)}

19. SNH's spending to cover costs that are not shared with the other oil companies as part of the production-sharing agreements are called autres charges (other costs). Some of this is related to SNH's mission, (e.g. decommissioning costs). Other elements of this spending are not related to SNH's oil sector activities and are quasi-fiscal in nature (e.g. the cost of operating the Chad-Cameroon oil pipeline).

\section{Subsidy to fuel consumers}

20. The budgetary transfer to SONARA to cover the fuel subsidy to consumers will amount to the difference between the retail price applied and the price that would be needed to keep SONARA's net result on domestic operations at zero, times the volumes sold by SONARA in the domestic market in the course of a given month. It will be calculated jointly by SONARA and CSPH and will be paid during the month $(\mathrm{t}+1)$ subsequent to the reference month ( $\mathrm{t}$ ) for which it has been calculated. The transfer to SONARA to cover the fuel subsidy for consumers will not exceed CFAF 6.25 billion at the end of the third quarter of 2007, CFAF 6.25 billion at the end of the fourth quarter of 2007, CFAF 6.25 billion at the end of the first quarter of 2008, and CFAF 6.25 billion at the end of the second quarter of 2008 . If, based on this mechanism, the quarterly budget transfer does not suffice to cover in full the consumer subsidy/SONARA's shortfall, the government will revise retail prices upward, on a monthly basis, so as to prevent losses on domestic operations at SONARA. If oil prices weaken on international markets, the government will first reduce transfers to SONARA and then eliminate them completely, before lowering the retail price.

\section{Modalities of the Contingency Mechanism for the Automatic Adjustment of Targets}

21. The floor on the nonoil primary balance will be adjusted upward by the amount of lower-than-programmed transfers made to SONARA.

22. The ceiling on net bank credit to the government will be adjusted:

- downward up to the amount of higher-than-programmed oil revenue and privatization proceeds that are not used to reduce domestic debt, buy back external debt owed to commercial creditors, or finance one-off investment projects (EBS 06/165, $\uparrow 15$ of the MEFP); 
- upward/downward by the amount of lower/higher-than-programmed external budget support (grants and loans) and by half of the amount of lower/higher than programmed debt relief (defined in paragraph 6 above); the revision upward will be capped to a cumulative amount of CFAF 15 billion in 2007 and CFAF 7.5 billion in the first half of 2008; for the purpose of the adjuster, budget support is defined as all untargeted grants and loans, excluding C2D, HIPC Initiative and MDRI grants;

- $\quad$ downward by the amount of lower-than-programmed restructuring expenditure;

- downward by the amount of lower-than-programmed payments of domestic debt (as defined above), excluding payments of the structured debt held by the domestic banking system, as entered in the line "Domestic financing, net - Banking System - Banking system excl. HIPC and C2D" in the "Central Government Operations" table).

23. Higher-than-programmed oil revenue and all privatization proceeds will be allocated to repayments of domestic debt (as defined above), buyback external debt owed to

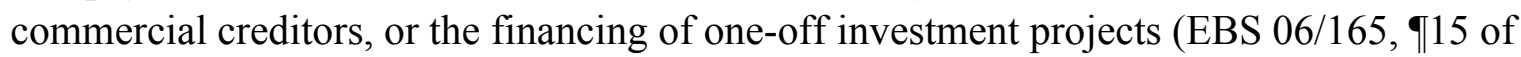
the MEFP). The domestic debt repayments will be made within one month following the end of the quarter in which the surplus occurred.

24. In case the shortfall/excess in oil revenue, external budget support (including debt relief), privatization revenue, and/or adjustments in the ceiling on net bank credit to the government exceed CFAF 20 billion, the government will consult with the staff of the IMF to formulate corrective policies.

\section{Program Exchange Rates}

25. Exchange rates to be applied for the conversion of amounts in SDR or U.S. dollars are US\$1.5315 per SDR and CFAF 479.22 per U.S. dollar for the third quarter of 2007; US\$ 1.5356 per SDR and CFAF 478.18 per U.S. dollar for the fourth quarter of 2007; US\$1.5356 per SDR and CFAF 478.38 per U.S. dollar for the first quarter of 2008; US\$1.5370 per SDR and CFAF 477.85 per U.S. dollar for the second quarter of 2008. Liabilities to the IMF, which are included in the definition of net bank credit to the government, will be valued at the same exchange rates. Any deviation from the exchange rate will lead to a full upward or downward adjustment, as appropriate, of the value of the stock of IMF liabilities to the BEAC, and to a similar adjustment of the ceiling on net bank credit to the government.

\section{E. Structural Performance Criteria}

26. The performance criterion pertaining to the adoption of a formula for revising the SONARA exit refinery price as well as of a simplified pricing structure for petroleum products allowing for automatic adjustment will be deemed to have been observed provided by end-December 2007 the fuel price formula reflects international prices, excludes the economic adjustment in favor of SONARA, allows for an automatic adjustment of fuel prices, and simplifies the tax structure. 
27. The performance criterion on supervision of CAMPOST will be considered observed if, by end-June 2008, the Ministry of Finance staff responsible for monitoring nonbank financial institutions prepare a report comprising the following data on the final quarter of 2007: (i) number of accounts opened, (ii) their allocation through the CAMPOST network, (iii) trends in balances, (iv) volume of saving invested and by partner, (v) the various characteristics of the investments, (vi) the interest charged on the investments, and (vii) the existence of minimum cash flow sufficient to accommodate withdrawals by savers at any time.

\section{F. Structural Benchmarks}

28. The benchmark pertaining to the completion of efforts to streamline taxpayer identification, upgrade the single identification software (IDU), and safeguard the single taxpayer file shall be considered observed if by end-December 2007 the following actions have been carried out: (1) the taxpayer registration software is operational; (2) this software is the sole electronic application for registering taxpayers (no other application can register or change the information pertaining to a taxpayer, whether at the central government level or in the provinces); and (3) the IDU application is accessible from the MESURE application for purposes of updating the large enterprise database (DGE database).

29. The benchmark for the 2008 budget law will be deemed to have been met if before end-December 2007, the law (i) is presented to Parliament, and (ii) is compatible with the fiscal program for 2008 .

30. The benchmark related to completion of the work to connect the General Directorate of Taxes (MESURE) to the General Directorate of Customs (ASYCUDA) will be considered observed if by end-March 2008, the physical infrastructure for information exchanges between the General Directorate of Taxes and the General Directorate of Customs is operational, and either module in these systems can share a specific dataset on the imports or exports of individuals or legal entities as well as on their commercial or industrial activities on the Cameroon market.

31. The benchmark pertaining to the installation of the automated integrated management system covering civil servants and payroll (SIGIPES) in 24 ministries will be considered observed if at end-June 2008: (i) the equipment, the protocol for communication between the various SIGIPES sites, and the SIGIPES application are in place in each of these ministries; (ii) staff have been trained in their use; (iii) the SIGIPES is operating effectively in the said ministries; and (iv) the personnel data of these ministries in the SIGIPES are consistent with the data in the payroll management system. The 24 ministries scheduled for SIGIPES software installation are the following: (1) the Office of the Prime Minister, (2) the Ministry of Higher Education, (3) the Ministry of Public Works, (4) the Ministry of Communication, (5) the Ministry of Forests and Wildlife, (6) the Ministry of Employment and Vocational 
Training; (7) the Ministry of Labor and Social Security, (8) the Ministry of Justice, (9) the Ministry of Economy, Planning, and Regional Development, (10) the Ministry of Environment and the Protection of Nature, (11) the Ministry of Agriculture and Rural Development, (12) the Ministry of Industry, Mines, and Technological Development, (13) the Ministry of Territorial Administration and Decentralization, (14) the Ministry of Water and Energy, (15) the Ministry of the Civil Service, (16) the Ministry of Basic Education, (17) the Ministry of Health, (18) the Ministry of Finance, (19) the Ministry of Secondary Education, (20) the Ministry of External Relations, (21) the Superior Audit Office (Contrôle Supérieure de l'Etat), (22) the Ministry of Urban Development and Housing, (23) the Ministry of Social Affairs, and (24) the Office of the General Delegation to the Sûreté Nationale.

32. The benchmark pertaining to the adoption of a medium-term tax reform plan will be considered observed if by June 30, 2008 the following actions have been taken: (1) the commission for the review of domestic and trade taxes has officially submitted its final report, including recommendations, to the Ministry of Finance; (2) a plan for the gradual implementation of the recommendations approved by the authorities is prepared and adopted. This plan will seek to achieve: (i) greater fairness in the tax system; (ii) greater efficiency; and (iii) greater mobilization of nonoil revenues.

33. The benchmark on adjustment of the retail prices of petroleum products and payment of budgetary transfers to SONARA as agreed with Fund staff will be considered met if the authorities raise the prices of the three main fuel products, i.e., premium gasoline, oil, and diesel fuel, and make transfer payments as indicated in paragraph 26 of the MEFP and paragraph 20 above (pertaining to subsidies for fuel consumers). Fuel prices are to be raised on the first business day of the month.

34. The benchmark related to the transfer of secondary-market transactions on zerocoupon Treasury bonds to the financial market will be considered met if by end-December 2007 all transactions (purchases, sales, repurchases) involving such bonds between individuals and legal entities, or between the government and other entities (including public enterprises) can take place on the financial market. By end-December 2007, the CAA will be capable of publishing each day the volume and prices for all transactions on the website: caa.gov.cm.

35. The benchmark related to the presentation to Parliament of the law on electronic communications and electronic payments of banks will be considered met if by end-June 2008 the government has submitted to Parliament a law defining the regulatory framework for electronic communications and payments in consultation with World Bank staff, including transactions between individuals or legal entities on the one hand and banks on the other. 
36. The benchmark related to completion and implementation of the electronic one-stopshop at the port of Douala to facilitate foreign trade will be considered met if, by end-June, 2008, the following operations can be truly carried out by e-users at the port of Douala: (i) access to the GUCE portal; (ii) release of the manifest; (iii) settlement of customs taxes and duties; and (iv) production of statistics on port passage times.

\section{G. Reporting Requirements}

37. The Cameroonian authorities will send data, as per the attached Tables 1 and 2, to the IMF within the time limits set out in that table. The authorities will supply the IMF, on a timely basis, with any additional information that the IMF requests for the purpose of monitoring the implementation of the program. 
Table 1. Cameroon: Data-Reporting Requirements

\begin{tabular}{|c|c|c|c|}
\hline $\begin{array}{l}\text { Category of } \\
\text { Data }\end{array}$ & Table/Report & Frequency & Target Date \\
\hline \multirow[t]{16}{*}{$\begin{array}{l}\text { Financial and } \\
\text { monetary data }\end{array}$} & $\begin{array}{l}\text { Central bank balance sheet, consolidated commercial bank } \\
\text { balance sheet, monetary survey }\end{array}$ & Monthly & $\begin{array}{l}10^{\text {th }} \text { of the month for the } \\
\text { previous month's data for the } \\
\text { preliminary series }\end{array}$ \\
\hline & \multirow{3}{*}{ Net credit by the banking system to the central Government } & \multirow{3}{*}{ Monthly } & $\begin{array}{l}25^{\text {th }} \text { of the month for the } \\
\text { previous month's data for the } \\
\text { final series }\end{array}$ \\
\hline & & & $\begin{array}{l}10^{\text {th }} \text { of the month for the } \\
\text { previous month's data for the } \\
\text { preliminary series }\end{array}$ \\
\hline & & & $\begin{array}{l}25^{\text {th }} \text { of the month for the } \\
\text { previous month's data for the } \\
\text { final series }\end{array}$ \\
\hline & Interest rates & Irregular & $\begin{array}{l}\text { One week after new rates } \\
\text { announced }\end{array}$ \\
\hline & $\begin{array}{l}\text { Transactions through the HIPC Initiative and C2D accounts } \\
\text { opened at the BEAC, including credit and debit }\end{array}$ & Monthly & $\begin{array}{l}10^{\text {th }} \text { of the month for the } \\
\text { previous month's data }\end{array}$ \\
\hline & Status report on all Government deposits at the BEAC & Monthly & $\begin{array}{l}10^{\text {th }} \text { of the month for the } \\
\text { previous month's data }\end{array}$ \\
\hline & $\begin{array}{l}\text { Changes to domestic and custom taxes (budget law and } \\
\text { others) }\end{array}$ & Irregular & $\begin{array}{l}\text { Two weeks after the change } \\
\text { has been made }\end{array}$ \\
\hline & $\begin{array}{l}\text { Government financial operations table (TOFE) on a cash } \\
\text { basis, including revenue, expenditure, financing, and domestic } \\
\text { debt payments (including settlement of domestic arrears) }\end{array}$ & Monthly & $\begin{array}{l}\text { Three weeks after the end of } \\
\text { the month concerned for the } \\
\text { preliminary series. }\end{array}$ \\
\hline & & & $\begin{array}{l}\text { Eight weeks after the end of } \\
\text { the month for the final series }\end{array}$ \\
\hline & $\begin{array}{l}\text { Government financial operations table on a commitment basis } \\
\text { (head office) consistent with the TOFE on a cash basis }\end{array}$ & Monthly & $\begin{array}{l}\text { Three weeks after the end of } \\
\text { the month concerned for the } \\
\text { preliminary series }\end{array}$ \\
\hline & & & $\begin{array}{l}\text { Eight weeks after the end of } \\
\text { the month }\end{array}$ \\
\hline & $\begin{array}{l}\text { Treasury balances of a given month, including table on } \\
\text { expenditure paid but not authorized and the table reconciling }\end{array}$ & Monthly & $\begin{array}{l}\text { Three weeks after the end of } \\
\text { the month }\end{array}$ \\
\hline & the Treasury account at the BEAC and the Treasury balance. & & $\begin{array}{l}\text { Eight weeks after the end of } \\
\text { the month }\end{array}$ \\
\hline & $\begin{array}{l}\text { Report on the implementation of the domestic debt settlement } \\
\text { plan }\end{array}$ & Monthly & $\begin{array}{l}25^{\text {th }} \text { of the month for the } \\
\text { previous month's data }\end{array}$ \\
\hline & $\begin{array}{l}\text { Table on budgetary execution on a functional basis consistent } \\
\text { with the table on Government financial operations on a }\end{array}$ & Monthly & $\begin{array}{l}\text { Eight weeks after the end of } \\
\text { the month for the final series }\end{array}$ \\
\hline
\end{tabular}


Table 1. Cameroon: Data-Reporting Requirements

\begin{tabular}{|c|c|c|c|}
\hline \multirow[t]{5}{*}{$\begin{array}{l}\text { Category of } \\
\text { Data }\end{array}$} & Table/Report & Frequency & Target Date \\
\hline & $\begin{array}{l}\text { VAT refunds' balances (both refunds requested and refunds } \\
\text { paid) }\end{array}$ & Monthly & $\begin{array}{l}25^{\text {th }} \text { of the month for the } \\
\text { previous month's data }\end{array}$ \\
\hline & Investment budget execution report & Quarterly & $\begin{array}{l}\text { Two months after the end of } \\
\text { month concerned }\end{array}$ \\
\hline & $\begin{array}{l}\text { HIPC and C2D spending (commitments, authorizations, } \\
\text { payments) }\end{array}$ & Monthly & $\begin{array}{l}25^{\text {th }} \text { of the month for the } \\
\text { previous month's data }\end{array}$ \\
\hline & $\begin{array}{l}\text { SNH operations, including export volumes, exchange rates, } \\
\text { prices, values, operating costs (including a detailed list of } \\
\text { other costs), commitments, transferable balances, spending } \\
\text { advances (interventions directes), and balances transferred } \\
\text { (cash basis), dividends received, and dividends transferred. }\end{array}$ & Monthly & $\begin{array}{l}25^{\text {th }} \text { of the month for the } \\
\text { previous month's data }\end{array}$ \\
\hline \multirow{2}{*}{$\begin{array}{l}\text { Public } \\
\text { companies } \\
\text { data }\end{array}$} & $\begin{array}{l}\text { Payments of bills to public enterprises (SNEC, CAMTEL, } \\
\text { AES SONEL, CAMRAIL, and SONARA) }\end{array}$ & Monthly & $\begin{array}{l}20^{\text {th }} \text { of the month for the } \\
\text { previous month's data }\end{array}$ \\
\hline & $\begin{array}{l}\text { Payments made to or on account of CAMAIR (for bills, } \\
\text { subsidies, loans, arrears, etc.) }\end{array}$ & Monthly & $\begin{array}{l}20^{\text {th }} \text { of the month for the } \\
\text { previous month's data }\end{array}$ \\
\hline $\begin{array}{l}\text { Fuel products } \\
\text { pricing data }\end{array}$ & $\begin{array}{l}\text { International oil prices, domestic fuel prices and their } \\
\text { components, budgetary transfers to SONARA, and SONARA } \\
\text { net financial result, using the format of Table } 2 \text { below. }\end{array}$ & Monthly & $\begin{array}{l}20^{\text {th }} \text { of the month for the } \\
\text { previous month's data }\end{array}$ \\
\hline \multirow[t]{7}{*}{$\begin{array}{l}\text { Real sector } \\
\text { data }\end{array}$} & Consumer price index, Yaoundé and Douala & Monthly & $\begin{array}{l}20^{\text {th }} \text { of the month for previous } \\
\text { month's data }\end{array}$ \\
\hline & National consumer price index & Quarterly & $\begin{array}{l}\text { Six weeks after the end of the } \\
\text { quarter concerned }\end{array}$ \\
\hline & Index of industrial production & Quarterly & $\begin{array}{l}\text { Two months after the end of } \\
\text { the preceding quarter }\end{array}$ \\
\hline & \multicolumn{3}{|l|}{ National accounts } \\
\hline & - $\quad$ Flash series & Annual & $\begin{array}{l}\text { Eight months after the end of } \\
\text { the year }\end{array}$ \\
\hline & - $\quad$ Provisional series & Annual & $\begin{array}{l}\text { Eighteen months after the end } \\
\text { of the year }\end{array}$ \\
\hline & Final series & Annual & $\begin{array}{l}\text { Twenty four months after the } \\
\text { end of the year }\end{array}$ \\
\hline \multirow[t]{4}{*}{$\begin{array}{l}\text { Balance of } \\
\text { payments data }\end{array}$} & Imports by use and major export products, trade balance & Monthly & $\begin{array}{l}\text { 25th of the month for the } \\
\text { previous month }\end{array}$ \\
\hline & $\begin{array}{l}\text { Preliminary price and volume indices of imports and of } \\
\text { exports }\end{array}$ & Quarterly & $\begin{array}{l}\text { One month after the end of the } \\
\text { quarter concerned }\end{array}$ \\
\hline & Final price and volume indices of imports and exports & Quarterly & $\begin{array}{l}\text { Three months after the end of } \\
\text { the quarter concerned }\end{array}$ \\
\hline & Balance of payments & Annual & $\begin{array}{l}\text { Six months after the end of the } \\
\text { year for the preliminary series } \\
\text { Twelve months after the end }\end{array}$ \\
\hline
\end{tabular}


Table 1. Cameroon: Data-Reporting Requirements

\begin{tabular}{|c|c|c|c|}
\hline $\begin{array}{l}\text { Category of } \\
\text { Data }\end{array}$ & Table/Report & Frequency & Target Date \\
\hline \multirow[t]{5}{*}{$\begin{array}{l}\text { External debt } \\
\text { data }\end{array}$} & Stock of outstanding debt and arrears & $\begin{array}{l}\text { At least } \\
\text { annual }\end{array}$ & $\begin{array}{l}\text { of the year for the final series } \\
\text { At the beginning of the year; } \\
\text { updates as needed }\end{array}$ \\
\hline & Debt service due after debt relief & Monthly & $\begin{array}{l}25^{\text {th }} \text { of the month for the } \\
\text { previous quarter's data }\end{array}$ \\
\hline & Debt service paid & Monthly & $\begin{array}{l}25^{\text {th }} \text { of the month for the } \\
\text { previous quarter's data }\end{array}$ \\
\hline & $\begin{array}{l}\text { New grants and loans received, specified by creditor including } \\
\text { their terms and conditions and project }\end{array}$ & Monthly & $\begin{array}{l}25^{\text {th }} \text { of the month for the } \\
\text { previous quarter's data }\end{array}$ \\
\hline & Grants and loans projected for the next eight quarters & Quarterly & $\begin{array}{l}25^{\text {th }} \text { of the month for the } \\
\text { previous quarter's data }\end{array}$ \\
\hline
\end{tabular}




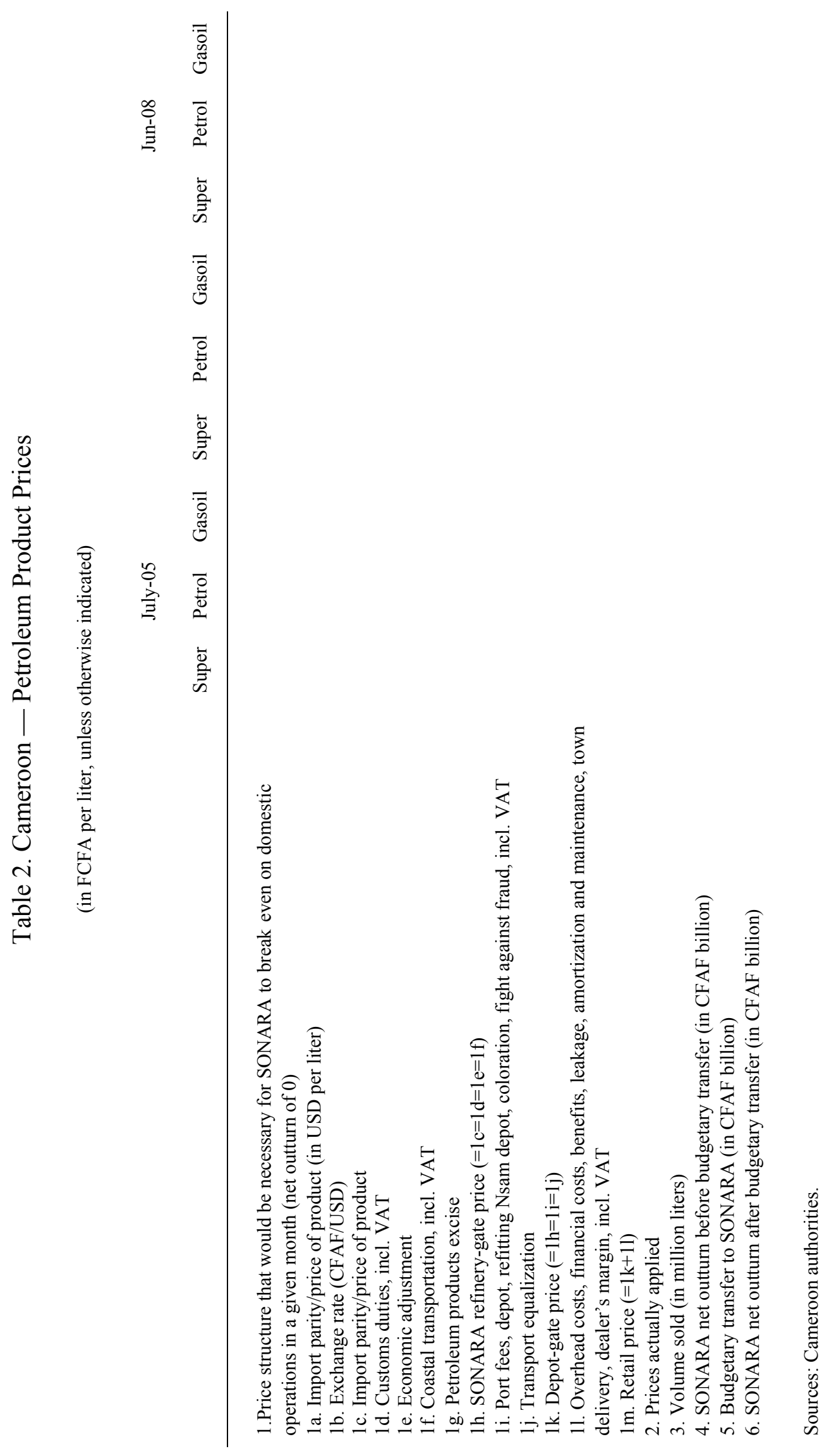




\section{INTERNATIONAL MONETARY FUND}

\section{CAMEROON}

Fourth Review Under the Three-Year Arrangement Under the Poverty Reduction and Growth Facility, Request for Waiver of Performance Criterion, and Financing Assurances Review-Informational Annex

Prepared by the African Department

Approved by David Nellor and Adnan Mazarei

November 30, 2007

Contents

Page

Annexes

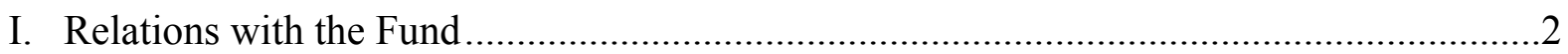

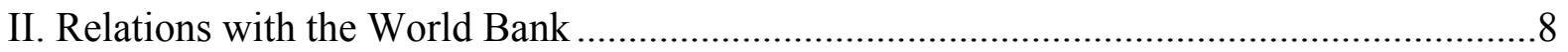

III. Table of Common Indicators Required for Surveillance ..................................................12 


\section{Cameroon: Relations with the Fund}

(As of September 30, 2007)

I. Membership Status: Joined 07/10/1963; Article VIII

II. General Resources Account:

Quota

Fund holdings of currency

Reserve position in Fund

III. SDR Department:

Net cumulative allocation

Holdings

IV. Outstanding Purchases and Loans:

PRGF arrangements

V. Latest Financial Arrangements:

$\begin{array}{ccccc}\text { Type } & \begin{array}{c}\text { Date of } \\ \text { Arrangement }\end{array} & \begin{array}{c}\text { Expiration } \\ \text { date }\end{array} & \begin{array}{c}\text { Amount approved } \\ \text { (SDR million) }\end{array} & \begin{array}{c}\text { Amount drawn } \\ \text { (SDR million) }\end{array} \\ \text { PRGF } & 10 / 24 / 2005 & 10 / 23 / 2008 & 18.57 & 10.60 \\ \text { PRGF } & 12 / 21 / 2000 & 12 / 20 / 2004 & 111.42 & 79.59 \\ \text { PRGF } & 08 / 20 / 1997 & 12 / 20 / 2000 & 162.12 & 162.12\end{array}$

\begin{tabular}{rr} 
SDR million & \%Quota \\
\hline 185.70 & 100.00 \\
184.97 & 99.61 \\
0.74 & 0.40
\end{tabular}

$\underline{\text { SDR million }}$

24.46

\%Allocation

100.00

12.51

$\underline{\text { SDR million }}$

10.60

$\frac{\% \text { Quota }}{5.71}$ 
VI. Projected Payments to Fund (SDR million; based on existing use of resources and present holdings of SDRs)

Forthcoming

\begin{tabular}{|c|c|c|c|c|c|}
\hline & $\underline{2007}$ & $\underline{2008}$ & $\underline{2009}$ & $\underline{2010}$ & $\underline{2011}$ \\
\hline Principal & & & & & 0.80 \\
\hline Charges/interest & 0.24 & 0.87 & 0.86 & 0.87 & 0.86 \\
\hline Total & 0.24 & 0.87 & 0.86 & 0.87 & 1.66 \\
\hline
\end{tabular}

VII. Implementation of HIPC Initiative:

Enhanced

framework

I. Commitment of HIPC assistance

Decision point date

Oct 2000

Assistance committed ${ }^{1}$

By all creditors (US\$ million)

$1,267.00$

Of which: Fund assistance (US\$ million)

37.04

(SDR equivalent in millions)

28.62

Completion point date

Apr 2006

II. Delivery of Fund assistance (SDR million)

Amount disbursed

Interim assistance

Completion point

17.37

Additional disbursement of interest income ${ }^{2}$

Total disbursements

${ }^{1}$ Assistance committed under the original framework is expressed in net present value (NPV) terms at the completion point, and assistance committed under the enhanced framework is expressed in NPV terms at the decision point. Hence these two amounts can not be added.

${ }^{2}$ Under the enhanced framework, an additional disbursement is made at the completion point corresponding to interest income earned on the amount committed at the decision point but not disbursed during the interim period. 
VIII. Implementation of MDRI Assistance:

I. $\quad$ MDRI-eligible debt (SDR million) ${ }^{1} \quad 173.26$

Financed by: MDRI Trust $\quad 149.17$

Remaining HIPC Resources $\quad 24.09$

II. Debt Relief by Facility (SDR million)

Eligible Debt

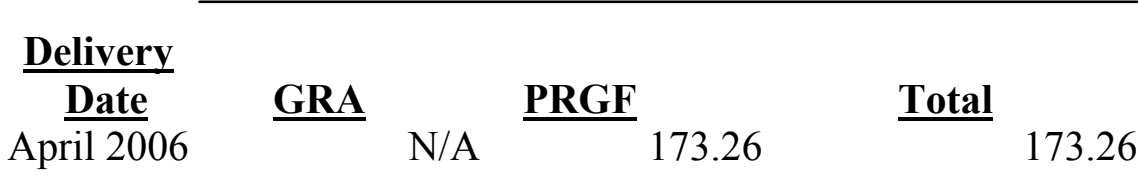

${ }^{1}$ The MDRI provides 100 percent debt relief to eligible member countries that qualified for the assistance. Grant assistance from the MDRI Trust and HIPC resources provide debt relief to cover the full stock of debt owed to the Fund as of end-2004 that remains outstanding at the time the member qualifies for such debt relief.

\section{Safeguards Assessments:}

The Bank of the Central African States (BEAC) is the regional central bank of Central African States, of which Cameroon is a member. A safeguard assessment of the BEAC completed on August 30, 2004 found that BEAC has implemented a number of measures to strengthen its safeguards framework since the 2001 safeguards assessment, but further progress needs to be made in key areas. A summary of the recommendations of the safeguards assessment was reported in Country Report No. 07/285.

\section{Exchange Arrangements:}

Cameroon participates in a currency union with five other members of the CEMAC and has no separate legal tender. Cameroon's currency, the CFA franc, is pegged to the euro at the fixed rate of CFAF 655.957 per euro. Local currency equivalent: CFAF 706.7 = SDR 1, as of November 30, 2007. Effective January 1, 2007, the exchange arrangement of the CEMAC countries has been reclassified to the category of conventional pegged arrangement from the category of exchange arrangement with no separate legal tender. The new classification is based on the behavior of the common currency, whereas the previous classification was based on the lack of a separate legal tender. The new classification thus reflects only a definitional change, and is not based on a judgment that there has been a substantive change in the exchange regime or other policies of the currency union or its members.

Cameroon maintains an exchange system free of restrictions on the making of payments and transfers for current international transactions, except for restrictions maintained for security reasons that have been notified to the Fund pursuant to Executive Board decision 144$152 / 51$. 


\section{Article IV Consultation:}

The last Article IV consultation with Cameroon was concluded by the Executive Board on June 18, 2007.

\section{FSAP Participation and ROSCs:}

The Financial System Stability Assessment (FSSA) report of May 24, 2000 is based on the findings of the joint IMF-World Bank mission that visited Cameroon during February 29March 14, 2000. The findings of the Financial Sector Assessment Program (FSAP) mission were presented to the authorities on March 13-14, 2000 in the context of the 2000 Article IV consultation. An updated assessment was carried out by a joint IMF-World Bank FSAP mission in June 2007.

The Report on the Observance of Standards and Codes (ROSC) on fiscal transparency and transparency of monetary and financial policies was issued on June 16, 2000.

The data module of the ROSC was issued on August 24, 2001 (CR/01/150).

\section{Technical Assistance:}

Since September 2005: presence of an FAD resident expert for fiscal administration (shared with other countries in the region).

October 2006: FAD mission on poverty and social impact assessment of the current petroleum price mechanism.

October 2006: FAD mission (jointly with World Bank) to assess preparation of the new organic budget law, and review expenditure classification system.

March 2006: STA mission on balance of payments statistics compilation.

July 2005: FAD mission on tax policy.

May 2005: FAD mission on tax and customs administration.

December 2004: STA mission on the compilation of national accounts and follow-up by FAD expert on public expenditure management.

October 2003: STA mission on the compilation of national accounts. 
September 2003: FAD mission on non-oil revenue mobilization and follow-up by FAD expert on public expenditure management.

June 2003: FAD mission on public expenditure management.

March 2003: FAD mission on public expenditure management.

November 2002: FAD mission on public expenditure management.

May 2002: FAD mission on public expenditure management.

April 2002: FAD mission follow-up on the personal income tax system.

March 2002: FAD mission on the implementation of the action plan for government revenue and expenditure.

October-November 2001: FAD mission on tax and customs administration.

September 2001: FAD missions on the audit of the treasury and poverty tracking.

June 2000: FAD mission on the modernization of customs.

April 2000: STA mission on General Data Dissemination System (GDDS/ROSC).

November 1999: FAD mission on modernization of the tax department.

June-July 1999: FAD technical assistance mission on customs.

May-June 1999: FAD follow-up mission on value-added tax (VAT) and tax administration.

January-March 1999: Placement of an FAD advisor for the introduction of the VAT.

November 1998: Placement of an FAD resident advisor on public expenditure management.

October-November 1998: STA mission on metadata project.

September 1998: Placement of FAD advisor for the VAT.

July 1998: FAD mission on preparation of a VAT.

February 1998: FAD technical assistance mission on review of public expenditure management. 
November 1997: FAD technical assistance mission on preparation for the introduction of the VAT.

January-February 1997: AFR/PDR mission, in collaboration with experts from the World Bank and the French government, on external debt statistics.

May 1996: AFR mission, in collaboration with a team from the French Treasury and the Banque de France, on the system of fiscal reporting and monitoring.

February 1996: FAD mission on direct taxation and agricultural sector taxation.

May-June 1995: STA mission on balance of payments statistics.

\section{Resident Representatives:}

The post of IMF Resident Representative has been maintained in Yaoundé continuously since 1989. The current Resident Representative, Ms. Kabedi-Mbuyi, has been in her post since July 2005. 


\section{Cameroon: Relations with the World Bank}

(As of October 30, 2007)

\section{Government's Strategy Supported by the World Bank}

1. The government's strategy for economic growth and poverty reduction, as described in the poverty reduction strategy paper (PRSP) communicated to the World Bank and the IMF in April 2003, is articulated along seven pillars, as detailed in IDA/SecM2003-0434. The Government has begun revising the PRSP, with an expected completion date of early 2008.

\section{World Bank Lending and Strategy}

2. A joint IDA-IFC Interim Strategy Note (ISN) was presented to the Board on December 7, 2006. The strategy, which covers fiscal year (FY) 07-08, maintains the broad objectives of the previous Country Assistance Strategy but with enhanced emphasis on governance including combating corruption, managing for results, and strengthening partnerships, and alignment and harmonization of external assistance in line with the Paris Declaration for aid effectiveness. World Bank's support to the Government's strategy is integrated around six proposed outcomes:

3. Strengthening PRSP implementation: Planned activities include policy dialogue and technical assistance to support revision of the PRSP, with a focus on sharpened priorities and an explicit results framework, including monitoring and evaluation mechanisms.

4. Strengthening governance, including anticorruption and public finance management: Activities include planned financing of an operation to increase transparency and accountability as well as planned programmatic support to strengthen public financial management as part of a multi-donor platform; ongoing policy dialogue and technical assistance to support implementation of the Extractives Industries Transparency Initiative (EITI); and support to anticorruption efforts. Corruption assessments will be conducted in key sectors as part of a coordinated support effort by international partners initiated by the Bank and linked to OECD-DAC efforts to develop a common anticorruption policy. An assessment of corruption in the health sector was completed in July 2007.

5. Fostering private sector development: Activities include enhanced IFC support to small enterprises; stepped-up IFC/Bank policy dialogue and technical assistance to strengthen Cameroon's weak business climate, including through a jointly appointed senior IFC/Bank staff based in Cameroon; and support to tighter regional integration, through an ongoing regional payment systems operation and a planned operation to strengthen regional financial institutions. 
6. $\quad$ Supporting infrastructure and urban development: Activities include ongoing financing of the Douala infrastructure, the railway concession, the regional air transport safety and security operations, an urban and water development project, and a regional transport and trade facilitation operation; as well as a planned energy sector operation and an ongoing policy dialogue on energy issues.

7. Supporting the forestry and environment sectors and strengthening rural and agricultural development: Activities include ongoing financing of the multi-partnersupported forestry and environment program, the community development program, and an operation to strengthen petroleum environment management capacity; an ongoing ESW on forestry reform; and a planned rural investment climate assessment/value chain analysis as key input to the preparation of a Sector-wide approach (SWAp) in the agriculture sector.

8. Promoting human development: Activities include financing of an ongoing operation to increase capacity in the education sector, a planned follow-up multi-sectoral HIV/AIDS operation, and planned support of a SWAp in the health sector (FY08). Within the health SWAp, the Bank expects to provide financial support for capacity building, systems development, and delivery of basic health services: (i) strengthen the normative functions of the Ministry of Health; (ii) reinforce the capacity of provinces to manage, allocate, and plan resources, and to supervise, and monitor districts; and (iii) fund a basic package of services included in a consolidated health district plan which reflects sector priorities based on the updated Health Sector Strategy. The Bank has also completed a fiscal space study in the health sector.

9. As of October 30, 2007, the IDA portfolio (including GEF co-financing) comprises ten active projects with a total commitment of US\$431.1 million, of which US\$362.0 million are not disbursed yet. These projects cover a broad range of sectors, including infrastructure, education, transport, environment, forestry, local development, urban and water supply, and public-private partnerships for growth and poverty reduction. IDA also manages five grants with a total commitment of US\$2.5 million in the areas of governance (EITI) and PRSP preparation.

\begin{tabular}{|lr|}
\hline \multicolumn{2}{|c|}{ Table 1: World Bank Portfolio in Cameroon } \\
(commitments at October 30, 2007, in US\$ million) & \\
IDA Total & $\mathbf{4 3 1 . 1}$ \\
Douala Infrastructure & 55.6 \\
Community development program (IDA + GEF) & 26.0 \\
Public-private partnership for growth & 13.5 \\
Environment capacity building & 4.7 \\
Forest and environment development (IDA+GEF) & 35.0 \\
Urban and water sector development & 80.0 \\
Education & 40.7 \\
Railway Concession & 14.1 \\
Air Transport Safety and Security & 14.5 \\
CEMAC transport and transit facilitation program & 147.0 \\
\hline
\end{tabular}


10. In addition to its lending activities, the World Bank has been supporting the government with analysis and a policy dialogue in such areas as :

- Monitoring and assisting on the PRSP implementation (i) by providing assistance and formulating sector strategies, sector and global medium-term expenditure frameworks to align the national budget to the PRSP development objectives; (ii) carrying out an Investment Climate Assessment (ICA) in FY06 to sharpen PRSP policies for economic growth and diversification, and poverty reduction.

- Strengthening the dialogue and action on the governance agenda with an active role in (i) the Multidonor Platform on Public Finance that is working with the Government on improving public financial management, and (ii) working closely with other partners to support the government's efforts to combat corruption. To support these activities a Public Expenditure Management and Financial Accountability Review (PEMFAR) and a Country Procurement Assessment Review have been undertaken.

\section{IMF-World Bank Collaboration in Specific Areas}

11. The IMF and World Bank staffs collaborate on (i) the HIPC Initiative and the PRSP process and specifically worked jointly on the documents for the HIPC completion point and the JSAN of the PRSP progress report, which were presented to the Boards in April 2006; (ii) analyses and reforms in public financial management; and (iii) other governance reforms, including the customs systems. Table 2 briefly describes each area and the specific policy advice support provided by the two institutions.

12. The Fund takes the lead on policy advice and reforms related to (i) macroeconomic policy and short- and medium-term financial programming; (ii) tax policy and administration; (iii) information and financial management systems for government revenue; (iv) budget accounting; (v) treasury procedures; and (vi) expenditure classification and tracking. Bank staffs participate in the meetings of Fund missions with the authorities in these areas.

13. The World Bank takes the lead on (i) institutional and human capacity building for public sector management; (ii) anticorruption; (iii) budget planning and programming including formulation of sectoral strategies and medium-term expenditure frameworks; (iv) EITI implementation; (v) analysis of poverty and sources of growth to support the PRSP process, (vi) advice on sector development particularly the social sectors, infrastructure, agriculture, and forestry; (vii) the design, implementation and monitoring of the structural reform program including the privatization of public enterprises; and (viii) decentralization agenda. 
Table 2: Cameroon: Bank/Fund Collaboration

\begin{tabular}{|c|c|c|c|}
\hline Area & Description & $\begin{array}{l}\text { Specialized Advice/ } \\
\text { Reforms Supported by } \\
\text { Fund }\end{array}$ & $\begin{array}{l}\text { Specialized Advice/ Reforms } \\
\text { Supported by Bank }\end{array}$ \\
\hline $\begin{array}{l}\text { Public financial } \\
\text { management }\end{array}$ & $\begin{array}{l}\text { Bank and Fund missions analyzing } \\
\text { aspects of fiscal management }\end{array}$ & $\begin{array}{l}\text { Tax analysis and policies, } \\
\text { strengthening of control } \\
\text { agencies; expenditure } \\
\text { management, including } \\
\text { expenditure classification } \\
\text { treasury management; } \\
\text { transparency and reporting } \\
\text { in budget operations; budget } \\
\text { execution, monitoring and } \\
\text { evaluation }\end{array}$ & $\begin{array}{l}\text { Expenditure policy and budget } \\
\text { allocation; budget planning and } \\
\text { programming, including } \\
\text { preparation of global and sector } \\
\text { MTEFs; budget execution } \\
\text { evaluation } \\
\text { Public procurement reform } \\
\text { Budget tracking in key sectors }\end{array}$ \\
\hline $\begin{array}{l}\text { Other governance } \\
\text { reforms }\end{array}$ & $\begin{array}{l}\text { Coordination of Bank/Fund staff work } \\
\text { with UNDP on developing } \\
\text { implementation plans }\end{array}$ & Customs and tax reform & $\begin{array}{l}\text { Anticorruption agenda; } \\
\text { Decentralization } \\
\text { EITI }\end{array}$ \\
\hline Structural reforms & $\begin{array}{l}\text { Continuation of the structural reforms } \\
\text { required to sustain growth }\end{array}$ & $\begin{array}{l}\text { Trade policies; financial } \\
\text { sector reform }\end{array}$ & $\begin{array}{l}\text { Reforms in education, health, } \\
\text { transport, energy, rural } \\
\text { infrastructure, and urban } \\
\text { development } \\
\text { Restructuring and privatization of } \\
\text { public enterprises, including } \\
\text { CAMAIR, CAMTEL, SNEC, and } \\
\text { CAMPOST } \\
\text { Institutional and human capacity } \\
\text { building, including civil service } \\
\text { reform (pay issues) } \\
\text { Private sector development and } \\
\text { trade and transit policies } \\
\text { Financial sector strategy }\end{array}$ \\
\hline $\begin{array}{l}\text { HIPC completion } \\
\text { point and PRSP } \\
\text { related activities }\end{array}$ & $\begin{array}{l}\text { Joint tracking of HIPC- related spending } \\
\text { and the preparation of the HIPC } \\
\text { completion point documents and JSAN } \\
\text { of PRSP progress reports }\end{array}$ & & \\
\hline
\end{tabular}

14. Both the Bank and Fund have responsibility for policy advice on (i) budgetary procedures, government expenditure management systems, and expenditure execution, including tracking of poverty-reducing expenditures; (ii) the functioning of internal and external budget control institutions; (iii) customs reform; (iv) financial system reform; and (v) governance. The two institutions also jointly support and monitor the HIPC Initiative and PRSP process. Finally, the Bank and the Fund have jointly conducted a FSAP for the CEMAC region, and a joint FSAP for Cameroon.

Questions may be addressed to Abdoulaye Seck (Tel. 237-2220-3815) or Katrina Sharkey (Tel. 473-6288). 


\section{Cameroon: Table of Common Indicators Required for Surveillance}

(as of November 2, 2007)

\begin{tabular}{|c|c|c|c|c|c|}
\hline & $\begin{array}{c}\text { Date of } \\
\text { latest } \\
\text { observatio } \\
n\end{array}$ & $\begin{array}{l}\text { Date } \\
\text { received }\end{array}$ & $\begin{array}{c}\text { Frequenc } \\
\text { y of } \\
\text { Data }^{7}\end{array}$ & $\begin{array}{l}\text { Frequenc } \\
\text { y of } \\
\text { Reporting } \\
7\end{array}$ & $\begin{array}{l}\text { Frequency } \\
\text { of } \\
\text { publication } \\
7\end{array}$ \\
\hline Exchange Rates & $\begin{array}{l}\text { Sept. } \\
2007\end{array}$ & Oct. 2007 & M & M & M \\
\hline $\begin{array}{l}\text { International Reserve Assets and Reserve } \\
\text { Liabilities of the Monetary Authorities }^{1}\end{array}$ & Aug. 2007 & Oct. 2007 & M & M & M \\
\hline Reserve/Base Money & Aug. 2007 & Oct. 2007 & M & M & M \\
\hline Broad Money & Aug. 2007 & Oct. 2007 & M & M & M \\
\hline Central Bank Balance Sheet & Aug. 2007 & Oct. 2007 & M & M & M \\
\hline $\begin{array}{l}\text { Consolidated Balance Sheet of the Banking } \\
\text { System }\end{array}$ & Aug. 2007 & Oct. 2007 & M & M & M \\
\hline Interest Rates ${ }^{2}$ & $\begin{array}{l}\text { Sept. } \\
2007\end{array}$ & Oct. 2007 & M & M & M \\
\hline Consumer Price Index & Aug. 2007 & Oct. 2007 & M & Q & Q \\
\hline $\begin{array}{l}\text { Revenue, Expenditure, Balance and } \\
\text { Composition of Financing }^{3}-\text { General } \\
\text { Government }^{4}\end{array}$ & NA & NA & NA & NA & NA \\
\hline $\begin{array}{l}\text { Revenue, Expenditure, Balance and } \\
\text { Composition of Financing }{ }^{3}-\text { Central Government }\end{array}$ & Aug. 2007 & Oct. 2007 & M & M & $\begin{array}{l}\text { Partial } \\
\text { data } \\
\text { published } \\
\text { monthly. }\end{array}$ \\
\hline $\begin{array}{l}\text { Stocks of Central Government and Central } \\
\text { Government-Guaranteed Debt }\end{array}$ & Aug. 2007 & Oct. 2007 & M & M & M \\
\hline External Current Account Balance & 2004 & Oct. 2007 & A & A & NA \\
\hline Exports and Imports of Goods and Services ${ }^{6}$ & June 2007 & $\begin{array}{l}\text { Sept. } \\
2007\end{array}$ & M & M & NA \\
\hline GDP/GNP & Dec. 2006 & $\begin{array}{l}\text { Sept. } \\
2007\end{array}$ & A & A & NA \\
\hline Gross External Debt & $N / A$ & $\mathrm{~N} / \mathrm{A}$ & $N / A$ & $N / A$ & $N / A$ \\
\hline
\end{tabular}

${ }^{1}$ Includes reserve assets pledged or otherwise encumbered as well as net derivative positions.

${ }^{2}$ Both market-based and officially determined, including discount rates, money market rates, rates on treasury bills, notes and bonds.

${ }^{3}$ Foreign, domestic bank, and domestic nonbank financing.

${ }^{4}$ The general government consists of the central government (budgetary funds, extra budgetary funds, and social security funds) and state and local governments.

${ }^{5}$ Including currency and maturity composition.

${ }^{6}$ Goods only, data on trade in services are not available.

${ }^{7}$ Daily (D), Weekly (W), Monthly (M), Quarterly (Q), Annually (A), Irregular (I); Not Available (NA). 


\section{Statement by the IMF Staff Representative December 19, 2007}

This statement provides an update on recent economic developments based on information received after the staff report (Country Report No. 07/285) was finalized. The information provided below does not alter the thrust of the staff appraisal:

$>$ Inflation has declined, reflecting a deceleration of fuel prices and the impact of last year's tariff reductions on basic staples (fish, flour, and rice). Average inflation in the 12-month period through September declined to 0.5 percent, compared with 2.5 percent in June.

$>$ Preliminary data through September show that fiscal performance was broadly satisfactory despite slow economic activity. The nonoil primary deficit (program definition) was slightly ( 0.1 percent of GDP) higher-than-expected due to a shortfall in nonoil revenues. The underperformance in nonoil revenues in the third quarter was due to lower-than-projected nontax revenues, reflecting mainly lower dividend payments. Program spending was broadly in line with staff projections. The authorities are strengthening nonoil revenue collection by tightening controls, and enhancing the collection of tax arrears.

$>$ Progress was made on structural reforms. Preparations for the adoption of an automatic fuel pricing formula (proposed performance criterion for end-December) is nearing completion. Work related to the streamlining of the taxpayer identification, upgrading the single identification software, and safeguarding the single taxpayer file is proceeding as planned. Important progress has been made on the transfer of secondary-market transactions on zero-coupon treasury bonds to the financial market, expected to be completed by end-2007. The 2008 budget, broadly in line with the program, was approved by Parliament. As expected, the Parliament also approved a new budget organic law. Regarding public enterprise reform, the authorities selected in November a financial advisor for the privatization of the national airline (CAMAIR). Negotiations with the successful bidder for the management contract of the water company (SNEC) are continuing, and the contract is expected to be signed shortly. The authorities have finished the technical evaluation of proposals for the privatization of CAMTEL and are considering the next steps.

$>$ The new government that took office in September has pursued efforts to strengthen relations with the international donor community. Donors have pledged to work closely with the government to continue strengthening the public financial management system to ensure effective use of debt relief resources.

$>$ The authorities are in the process of finalizing signature of the bilateral agreement with the last remaining Paris Club creditor. 
December 19, 2007

\section{IMF Executive Board Completes Fourth Review Under the PRGF Arrangement with Cameroon and Approves US\$4.1 Million Disbursement}

The Executive Board of the International Monetary Fund (IMF) today completed the fourth review of Cameroon's economic performance and the review of financing assurances under a three-year Poverty Reduction and Growth Facility (PRGF) arrangement. The Executive Board also approved Cameroon's request for a waiver of the non-observance of a performance criterion pertaining to the preparatory work for the establishment of a financial subsidiary for the Cameroon Postal Services Company (CAMPOST) on the basis of corrective action taken.

The completion of this review enables the release of an amount equivalent to SDR 2.65 million (about US\$4.1 million), bringing total disbursements under the arrangement to SDR 13.25 million (about US\$20.7 million).

The three-year PRGF arrangement for Cameroon was approved by the Executive Board on October 24, 2005 (see Press Release No 05/236) in an amount equivalent to SDR 18.57 million (about US\$29.1 million).

The PRGF is the IMF's concessional facility for low-income countries. PRGF-supported programs are based on country-owned poverty reduction strategies designed in a participatory process involving civil society and development partners. PRGF loans carry an annual interest rate of 0.5 percent and are repayable over 10 years with a $5 \frac{1}{2}$-year grace period on principal payments.

At the conclusion of the Executive Board's discussion, Mr. John Lipsky, First Deputy Managing Director and Acting Chair, stated:

"The Cameroonian authorities are to be commended for their commitment to their reform agenda, whose steadfast implementation will be crucial to achieve the economic growth rates needed to significantly reduce poverty. Fiscal performance has been favorable and structural measures to strengthen public finance management have been implemented. These efforts should be complemented by determined implementation of reforms to improve investment execution, rural finance, and public enterprise performance. 
"Mobilization of non-oil revenues in the context of the expected decline in oil and traderelated revenues will be critical to finance priority spending and preserve fiscal sustainability. In this regard, efforts to expand the tax base will need to be accelerated.

"High priority needs to be given to improving the execution and quality of public spending. Gradual elimination of subsidies to public enterprises will help over time to create more fiscal space for priority spending. The authorities should continue efforts to strengthen public expenditure management and transparency, notably by better monitoring budget execution.

"Prudent debt management remains a priority in the post-debt-relief period to safeguard debt sustainability. In this regard, it will be important that borrowing continues to be on concessional terms.

"Strengthening the business environment requires decisive action to improve infrastructure, deepen financial intermediation, liberalize trade, reform public enterprises, and tackle corruption. In the period ahead, the authorities will implement the recommendations of the Financial Sector Assessment Program to strengthen the financial sector. Also, trade liberalization within the Central African Economic and Monetary Community is being advanced with the lowering of the common external tariff. Perseverance with public enterprise reforms and anti-corruption efforts will be essential to consolidate gains in economic efficiency and enhance the climate for private investment," Mr. Lipsky stated. 


\section{Statement by Laurean W. Rutayisire, Executive Director for Cameroon December 19, 2007}

On behalf of my Cameroonian authorities, I would like to thank Executive Directors and Management for their continued support to Cameroon's efforts towards sustained growth and economic development. I would also like to thank staff for constructive policy dialogue and fruitful exchanges during their recent visit to Yaounde. As has been the case with staff reports on previous reviews, the authorities have expressed their consent to the publication of staff reports on the fourth review.

Cameroon's continued satisfactory implementation of Fund-supported program is a vivid testimony of strong ownership of reforms. Indeed, performance under the PRGF was broadly satisfactory. Real economic growth remained strong, albeit at lower pace. All performance criteria and quantitative targets for end-June 2007 were met, with the exception of the performance criterion on preparatory work for the establishment of a financial subsidiary for the postal services and the benchmark on non-oil revenue. My authorities took swift corrective actions when necessary to maintain the momentum of the reform program. The implementation of structural reforms also moved forward, in particular in the areas of public finance and transparency.

Cameroon's growth prospects remain favorable. Nonetheless, the key challenge facing the authorities is to foster growth and translate sound economic performance into significant poverty reduction. Indeed, debt relief has generated expectations of civil service salary adjustment and better public service delivery. In this context, a government reshuffle took place in September 2007, following parliamentary elections. The mandate of the new government is to focus on accelerating pro-poor economic growth, while maintaining macroeconomic stability. To this end, the authorities are adopting measures to reorient investment expenditure toward agriculture development and agricultural-related infrastructure projects. As for maintaining macroeconomic stability, the authorities have taken the right policy-mix to offset supply-side shocks and sluggish productivity. In their reform efforts, the authorities are hopeful that they can continue to rely on additional and timely support of the international community.

\section{Recent Economic Developments}

Economic performance in the first half of 2007 was not as strong as projected. Real GDP growth dropped to 2.9 percent, owing to poor performance in agriculture stemming from increased competition from low-cost producers, falling prices and productivity in the cotton sector and lower-than-expected public investment. Economic activity picked-up at the end of the first semester, thanks to a recovery in construction and agriculture, as well as timber and higher oil prices. The external sector improved, as higher imports were more than 
offset by oil and non-oil exports. The latter was driven by the accumulation of non-exported timber in 2005.

In the monetary area, although net foreign assets increased in the first half of 2007, monetary growth was contained by a decline in net credit to government and lower credit to the private sector made possible by the acceleration of domestic debt payments. Inflation declined further, as fuel price increases moderated and the authorities reduced VAT and custom duties on basic food imports (rice, fish and flour), in order to contain inflationary pressures. As a result, average inflation declined further. The REER also continued to appreciate, due to a stronger Euro to which the CFAF is pegged.

As noted by staff, fiscal performance was broadly satisfactory despite slow economic activity. The overall fiscal surplus was higher than projected despite a revenue shortfall, reflecting lower-than-projected expenditure. The benchmark on non-oil revenue was missed due to reduced taxation on some basic imported staples and delays in dividend transfers from some government entities. To maintain the tax collection momentum, the authorities reinforced revenue administration measures. On the expenditure side, program spending was broadly in line with staff projections. While domestically financed investment outlays were on the rise, foreign-financed and MDRI/HIPC investments continued to experience lowerthan-budgeted disbursement, due to delays in project planning and implementation.

In the structural area, progress was also noticeable. Significant inroads were achieved in budget management and transparency, notably with the establishment of an IT connection between payroll and civil service files, the publication of budget execution and accounts for the oil sector and SOEs on a regular basis. As expected, the parliament recently approved a new budget organic law. The authorities have also stepped-up the fight against corruption with the setting up of the National Anti-Corruption Commission (CONAC), the launching of its first investigations and the recent conviction to heavy sentences of senior government officials involved in corruption cases. As regards civil service reform, the benchmark to conduct a diagnostic study of the civil service was met in spite of some delays. Indeed, personnel records were harmonized, but the new management system could not be installed as envisaged, due to a change in the choice of information technology. Regarding public enterprise reform, the authorities selected in November 2007 a financial advisor for the privatization of the airline company (CAMAIR). Negotiations are underway with the provisional bidder selected for the management contract of the water company (SNEC), and the technical evaluation of proposals for the privatization of CAMTEL have been finalized.

In the financial sector, the performance criterion related to preparatory work for the establishment of a financial subsidiary for CAMPOST was implemented with delays, as this process has proven more complex than expected, given the legal status of CAMPOST and the nature of its activities. In view of the corrective measures taken by the authorities, I 
request, on behalf of my Cameroonian authorities, the Board to approve the requested waiver.

Economic Policies and Structural Reforms Going Forward

Prospects for Cameroon's economy remain favorable, reflecting a stronger economic stimulus stemming from increased capital spending financed by external debt relief under the HIPC Initiative and the MDRI. Non-oil real GDP growth is expected to rebound to 3.4 percent in 2007 and about 4.5 percent in 2008, owing to higher public investment and a recovery in agriculture and services. Inflation will abate, albeit remaining sensitive to food imports. The external situation will weaken, reflecting a declining dollar and the expected decline in oil production.

Fiscal Policy and Reform

The authorities' medium-term fiscal strategy aims at increasing priority spending to accelerate growth and poverty reduction, while preserving macroeconomic stability. To this end, the 2008 budget recently adopted by the parliament, in line with the medium-term fiscal strategy and the original program aims at increasing non-oil fiscal revenue to create fiscal space for priority outlays, containing current expenditure and increasing capital spending in priority areas such as infrastructure, agriculture, health and education.

On the revenue side, given the expected decline of oil revenue and trade liberalization, increasing non-oil revenue mobilization remains critical in the authorities' agenda for fiscal sustainability. To this end, the authorities intend to accelerate the implementation of administrative measures, including streamlining of the taxpayer identification to enhance revenue mobilization, upgrading the single identification software and expanding the coverage of taxpayers in the main urban centers. Work related to these measures is proceeding as planned. Should these administrative measures prove insufficient to meet non-oil revenue targets, the authorities stand ready to step up their efforts with policy measures. In this context, the authorities are determined to preserve the tax base by refraining from introducing new tax exemptions or incentives that would result in a revenue loss or potential distortion. They also intend to improve revenue mobilization in the forestry sector and draft a medium-term taxation reform plan with the objective of fostering efficiency and fairness.

On the expenditure side, it is the authorities' intention to continue to abide by the need for prudence in the conduct of fiscal policy, while accelerating public investment in the priority sectors identified in the PRSP. In this context, my authorities intend to increase capital spending by 1 percentage point of GDP, with a focus on priority outlays. To create room for these outlays and accommodate for the wage bill increase, the authorities will contain current expenditure through lower subsidies and transfers. They will also pursue a 
prudent hiring policy and gradually increase salaries within a stable and sustainable mediummacroeconomic framework to enhance efficiency of the civil service, combat corruption, and improve the economic welfare of civil servants. To this end, the authorities have regularized the status of about 18,000 contractual employees, mainly in health and education and adjusted wages for incumbent civil servants whose promotions have not been met with salary increases over the last few years. These efforts will be fostered on the basis of a comprehensive diagnostic of the civil service remuneration aimed at correcting wage differences. The authorities are committed to continue using any windfall in oil revenue exclusively for the payment of domestic and external debt and for financing investment projects in the priority sectors.

Improving public finance management and transparency will continue to rank high on the authorities' agenda. In this regard, the authorities intend to produce the government financial operations table (TOFE) on a commitment basis and pursue procurement reforms, by periodically assessing the public procurement system and systematically publishing the penalties imposed on those who fail to comply with these regulations. The authorities will also step up efforts to accelerate the execution of capital spending, while implementing safeguards to ensure the quality of each project, notably by taking steps to ease constraints on HIPC and C2D financing, to strengthen the government's capacity for planning, preparing, evaluating and executing projects. They will also ensure the availability of counterpart funds, prepare a roadmap for the multiyear execution of the investment budget and increase the use of public private partnerships to create more fiscal space and improve efficiency for social as well as infrastructure projects.

Structural Reforms

The authorities will continue their ongoing civil service reforms to establish a solid basis for determining staffing levels and the payroll. To this end, they are working closely with the World Bank to devise a strategy for civil service reform. In the petroleum sector, the government intends to adopt a system for full pass-through of fuel prices, gradually eliminate fuel price subsidies and use the resulting budget savings to improve social safety net. Preparations for the adoption of an automatic pricing formula are nearing completion. To reduce budget transfers, the government is also working on the implementation of measures to bolster the financial position of SONARA.

In the financial sector, based on the FSAP recommendations, the authorities have decided to prepare an action plan for strengthening financial intermediation. At the national level, the authorities will take measures to facilitate access to credit. At the regional level, the government will support the establishment of the central credit registry. To provide alternative sources of financing to the economy, the authorities intend to pursue efforts to develop the securities market by allowing the transfer of secondary-market transactions on zero-coupon treasury bonds to the financial market and by replacing Central Bank's statutory 
advances to the government with the issuance of publicly-traded government securities. Based on the results of the business plan for CAMPOST financial activities, the government will determine the appropriate structure to put in place, in order to improve access to finance for the poor.

Turning to governance, the authorities are determined to enhance transparency and combat corruption in an effort to improve the business environment and the quality of public expenditure. For the latter, they intend to take steps to facilitate the asset disclosure of senior government officials, keep publishing on the internet the summary of the reports monitoring the physical and financial implementation of capital investment projects as well as judicial decisions and sanctions against civil servants. To improve the business environment, the authorities have decided to implement a one-stop shop for business creation to reduce time and costs involved in setting up a business and to prepare a private sector development strategy.

The authorities also intend to bolster regional integration, by increasing coordination with their CEMAC partners to reduce obstacles to sub-regional trade, implement the Common External Tariff (CET), eliminate the minimum administrative values for all imported products and find a common ground with the European Union on the Economic Partnership Agreement in a way agreeable to all parties.

As regards external debt management, the authorities will pursue a prudent debt policy and ensure that its debt is managed on a sustainable manner. Building on progress achieved thus far, the authorities are planning to clarify the legal and institutional framework of debt management, set an indebtedness ceiling and define priorities for debt management with the assistance of the Fund. They are also in the process of finalizing signature of the bilateral agreement with the last remaining Paris Club creditor.

Conclusion

My authorities have once again demonstrated their commitment to policies and reforms defined in the PRGF Program. Since the HIPC completion point, my authorities have achieved significant progress in the implementation of reforms and their ownership remains intact. In view of the overall satisfactory program performance since the last review under the PRGF-supported program, as reconfirmed in the most recent staff update, the broadly smooth implementation of the structural reform agenda, the corrective measures taken by the authorities to implement the performance criterion on the preparatory work for the establishment of a financial subsidiary of the postal services, and their renewed commitment to stay on course on program implementation for the period ahead, I would like to request, on behalf of my Cameroonian authorities, the Board's support for the completion of the fourth review under the PRGF and the request for waiver of the performance criterion. In light of the appropriate debt policies pursued by my authorities, including prudent borrowing policies 
and their good-faith efforts to reach agreements with the remaining private holders of the country's debt, I also request the Board's support for the completion of the financing assurances review. 